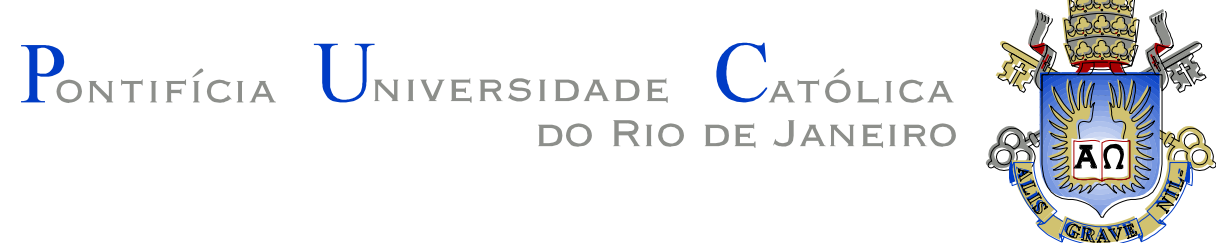

Igor Leonardo Romeiro Pereira

Arte e natureza na estética de Luigi Pareyson

Dissertação de mestrado

Dissertação apresentada ao Programa de Pósgraduação em Filosofia da PUC-Rio como requisito parcial para obtenção do título de Mestre em Filosofia.

Orientador: Prof. Luiz Camillo Osorio 


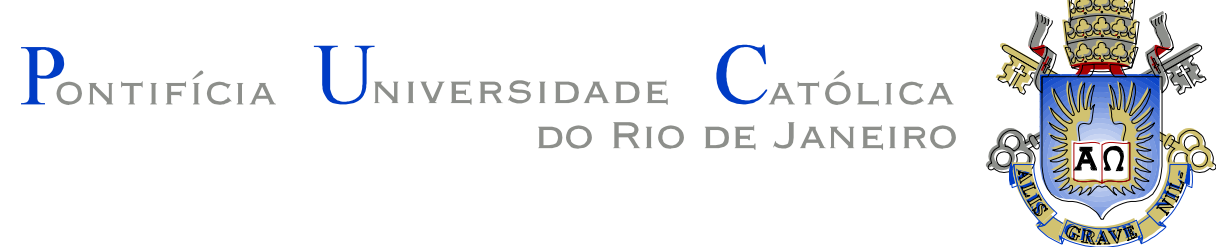

Igor Leonardo Romeiro Pereira

\section{Arte e natureza na estética de Luigi Pareyson}

Dissertação apresentada como requisito parcial para obtenção de grau de Mestre pelo Programa de Pósgraduação em Filosofia da PUC-Rio. Aprovada pela Comissão Examinadora abaixo assinada.

Prof. Luiz Camillo Dolabella Portella Osorio de Almeida

Orientador

Departamento de Filosofia - PUC-Rio

Prof. Pedro Duarte de Andrade Departamento de Filosofia - PUC-Rio

Prof. Virginia de Araujo Figueiredo

Departamento de Filosofia - UFMG

Prof. Denise Berruezo Portinari Coordenadora Setorial do Centro de Teologia e Ciências Humanas - PUC-Rio

Rio de Janeiro, 07 de abril de 2016 
Todos os direitos reservados. É proibida a reprodução total ou parcial do trabalho sem autorização da universidade, do autor e do orientador.

\section{Igor Leonardo Romeiro Pereira}

Graduou-se em Desenho Industrial pela Universidade Federal do Rio de Janeiro e em Filosofia pela Universidade do Estado do Rio de Janeiro. Possui especialização em Filosofia Medieval pela Faculdade de São Bento do Rio de Janeiro. É servidor público federal.

Ficha Catalográfica

Pereira, Igor Leonardo Romeiro

Arte e natureza na estética de Luigi Pareyson / Igor Leonardo Romeiro Pereira ; orientador: Luiz Camillo Osorio. - 2016.

$133 \mathrm{f.} \mathrm{;} 30 \mathrm{~cm}$

Dissertação (mestrado) - Pontifícia Universidade Católica do Rio de Janeiro, Departamento de Filosofia, 2016.

Inclui bibliografia

1. Filosofia - Teses. 2. Natureza. 3. Arte 4. Formatividade. 5. Belo natural. I. Osorio, Luiz Camillo. II. Pontifícia Universidade Católica do Rio de Janeiro. Departamento de Filosofia. III. Título. 


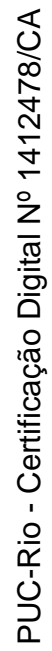

Ao João Vicente, mestre e amigo. 


\section{Agradecimentos}

A meu orientador, professor Luiz Camillo Osorio, pela atenção dedicada a este trabalho, pelo guiamento constante e seguro, e pela confiança em sua realização.

Aos membros da banca examinadora, professores Virgínia de Araújo Figueiredo e Pedro Duarte.

Ao professor Paulo Afonso de Araújo pelas sugestões, quando da avaliação de meu projeto.

Ao professor João Ricardo Moderno, graças a quem, num semestre já distante, tomei contato pela primeira vez com o pensamento de Pareyson.

Aos professores Maurizio Ferraris, Paolo D’Angelo e Paola Ricci Sindoni pelo generoso envio de artigos seus, que muito enriqueceram este estudo.

À Divisão de Bibliotecas e Documentação da PUC-Rio, por me facultar o acesso a inúmeros artigos, sem os quais este trabalho não teria sido feito.

À PUC-Rio, pelo apoio concedido, bem como aos professores e funcionários do Departamento de Filosofia.

A Sheila Gehrt e Oscar Bueno, por me permitirem conciliar minhas atividades profissionais e as muitas demandas da pesquisa.

À Aline Aimée, pelo carinho e zelo incondicionais, pela paciência e compreensão.

A meus pais e irmãs, meus primeiros e mais entusiásticos apoiadores. 


\section{Resumo}

Pereira, Igor Leonardo Romeiro; Osorio, Luiz Camillo. Arte e natureza na estética de Luigi Pareyson. Rio de Janeiro, 2016, 133p. Dissertação de Mestrado - Departamento de Filosofia, Pontifícia Universidade Católica do Rio de Janeiro.

Este trabalho investiga o estatuto da natureza no pensamento estético de Luigi Pareyson. Calcada em sua filosofia de feição existencialista, personalista e ontológica, sua teoria estética indica numa atividade - a formatividade - o elemento comum que garante algum caráter artístico a todo atuar humano e que, especificado, institui a arte em sua autonomia e independência, conferindo assim a máxima extensão à experiência estética. O problema da natureza surge aí enquanto esta - não sendo obra humana - se mostra sob dois aspectos: como limite extremo da fruição estética, no belo natural, e como modelo cujo operar a formatividade humana imita, na produção artística. Com base na descrição e na análise dos paralelos entre arte e natureza encontráveis na teoria - na descrição pareysoniana da obra de arte e de sua produção em termos organicistas, em sua teoria da interpretação conforme aplicada à natureza, e na reelaboração de ideias de Kant e Goethe - pretende-se compreender como a esfera natural pode ser afirmada como autônoma e formativa, tendo-se por base uma filosofia da pessoa em sua relação com o ser. E igualmente, de que modo se podem conciliar as valências naturalista e personalista da formatividade numa visão coerente do caráter estético comum à natureza e à arte. Tal exame se conclui pela defesa de que é o formar da pessoa a instância paradigmática em analogia e em contraste à qual se pensa e compreende o formar da natureza, com a consequente redução e subordinação de elementos metafísicos e naturalistas ao horizonte pessoalexistencial do pensamento do filósofo.

\section{Palavras-chave}

Natureza; Arte; Formatividade; Belo natural. 


\section{Abstract}

Pereira, Igor Leonardo Romeiro; Osorio, Luiz Camillo (Advisor). Art and nature in the aesthetics of Luigi Pareyson. Rio de Janeiro, 2016, 133p. MSc. Dissertation - Departamento de Filosofia, Pontifícia Universidade Católica do Rio de Janeiro.

This work investigates the role of nature in the aesthetic thought of Luigi Pareyson. His aesthetic theory, based on a philosophy of existentialist, personalistic and ontological features, embodies in one activity - formativity - the common element which grants an artistic character to every human act and which, when specified, installs art in its autonomy and independence, thus granting a maximum reach to aesthetic experience. The problem of nature arises since nature - being not a human product - presents itself under two forms: as the extreme limit of aesthetic fruition, in natural beauty, and as a model whose operation human formativity imitates, in artistic production. Based on the description and analysis of the parallels between art and nature in the theory - in the pareysonian description of the work of art and of its production in organicistic terms, in his theory of interpretation as applied to nature, and in his re-elaboration of Kant's and Goethe's ideas - this work intends to understand how the natural sphere can be affirmed as autonomous and formative, according to a philosophy of the person in their relation with being. And, also, to understand how the naturalistic and personalistic aspects of formativity can be reconciled into a coherent view of the aesthetic character shared by nature and art. This investigation concludes that personal formativity is the paradigm in analogy and in contrast to which nature's formative power can be conceived and understood, with a consequent reduction and subordination of naturalistic and metaphysical elements to the personalexistential horizon of Pareyson's thought.

\section{Keywords}

Nature; Art; Formativity; Natural beauty. 


\section{Sumário}

Introdução

1 Da filosofia à estética como filosofia 19

1.1. Pareyson e a filosofia 19

1.1.1. Existencialismo e personalismo 21

1.1.2. O conceito de pessoa 23

1.1.3. A hermenêutica 25

$\begin{array}{ll}\text { 1.1.4. O ser e a verdade } & 27\end{array}$

1.2. Pareyson e a estética 30

1.2.1. A estética como filosofia inteira 31

1.2.2. O pano de fundo: a estética de Croce 33

1.2.2.1. Arte e intuição 34

1.2.2.2. A arte no sistema do espírito 36

$\begin{array}{ll}\text { 1.2.2.3. Arte e natureza em Croce } & 38\end{array}$

2 Formatividade e natureza $\quad 41$

2.1. Arte e formatividade $\quad 41$

2.1.1. A formatividade 43

2.1.1.1. Atividades e operações 44

2.1.1.2. Leis e regras 46

2.1.2. O conceito de forma 47

2.1.2.1. A forma como organismo, resultado e modelo 49

2.1.2.2. Vida como produção de formas 52

2.1.3. Formatividade e especificação 53

2.1.3.1. Dimensão artística da experiência em geral 55

2.1.3.2. Arte como formatividade específica: realização e inovação 56

2.1.3.3. Conteúdo e estilo 58

2.1.3.4. A matéria na arte 60

2.2. Arte e natureza 62

2.2.1. Arte e imitação 63

2.2.1.1. A arte imita a natureza 65 
2.2.1.2. Formatividade natural

67

2.2.1.3. Caráter não natural da arte 69

2.2.2. O processo artístico 70

2.2.2.1. Esforço tentativo e desenvolvimento orgânico 72

2.2.2.2. Spunto, forma formante e forma formada 75

2.2.2.3. O artista e o gênio 79

3 Interpretação e natureza 82

3.1. A teoria da interpretação 82

3.1.1. Intuição e interpretação 83

3.1.2. Interpretação como encontro de pessoa e forma 86

3.1.3. A interpretação na arte 88

3.1.4. Beleza e contemplabilidade 93

3.2. Interpretar a natureza 98

3.2.1. Pareyson e Kant 99

3.2.1.1. Beleza aderente e juízo teleológico-estético 100

3.2.1.2. Ideias estéticas: produção e contemplação 102

3.2.1.3. Natureza como produtividade orgânica 103

3.2.2. O belo natural na teoria da formatividade 105

3.3. Metafísica da figuração: unificação estética de natureza e arte 109

3.3.1. A forma: síntese de contemplação e produção 110

3.3.2. Natureza e metafísica: o "Figurador" 112

3.3.3. Metafísica da figuração e a "virada ontológica" 114

$\begin{array}{ll}\text { Conclusão: natureza e filosofia da pessoa } & 118\end{array}$

Referências bibliográficas $\quad 128$

$\begin{array}{ll}\text { Bibliografia primária } & 128\end{array}$

Bibliografia secundária $\quad 129$ 


\section{Introdução}

O presente trabalho tem por objetivo investigar as relações entre natureza e arte a partir da teoria da formatividade, doutrina estética formulada entre as décadas de 50 e 60 do século XX pelo filósofo italiano Luigi Pareyson. Fá-lo-á com base num duplo movimento. Espera-se, por um lado, afirmar a importância de se reconhecer o âmbito da "esteticidade natural" para a validade e aplicabilidade de sua teoria; e se busca, por outro, compreender como esta mesma esteticidade se insere no pensamento personalista, existencialista e ontológico esposado pelo filósofo. A proposta que se pretende defender, ao fim, é que o "formar" pareysoniano enquanto atividade humana - assume caráter paradigmático não só para se entender a arte, mas também para a compreensão estética da natureza - sem prejuízo, porém, da autonomia que nesta se deve reconhecer, segundo a perspectiva filosófica do autor. Antes, porém, de esclarecer melhor este objetivo, e antes também de se expor o modo como se tentará alcançá-lo, cumpre justificar e defender a oportunidade mesma de empreender tal tarefa. Para tanto, devem-se explicitar antes de tudo as razões que motivaram este estudo, presidindo a escolha do tema e do autor abordados.

Como sugere Benedito Nunes, é útil distinguir entre os campos da Estética e da Filosofia da Arte (no sentido restrito de que o termo arte hoje se reveste), reconhecendo que o âmbito dos fenômenos estéticos não está circunscrito pelo da arte - ainda que nele encontre sua mais própria manifestação. ${ }^{1}$ Recorde-se, em apoio a isto, que a vocação estética do homem é atestada desde tempos remotíssimos, de modo que "a estética, tomada como vivência humana, é no mínimo tão antiga quanto o Homo sapiens sapiens". 2 Pode-se dizer, constatadas a abrangência e a humanidade próprias a esta experiência, que esta pesquisa nasceu de um interesse pessoal de refletir sobre aquelas formas da vivência estética que estão para além - ou aquém - das artísticas. Ou melhor:

\footnotetext{
${ }^{1}$ Cf. NUNES, B., Introdução à filosofia da arte, p. 15.

${ }^{2}$ OLIVEIRA, J. V. G.., Estética, vivência humana: temas e controvérsias na filosofia, p. 35.
} 
sobre os aspectos comuns que em alguma medida aproximam as experiências da arte e as demais experiências enquanto todas partícipes do domínio estético - por exemplo, nos campos da arte "aplicada", da técnica, da cultura (e mesmo da cultura de massas), do esporte, do ambiente natural, do entretenimento ou ainda das tarefas e ocupações da vida cotidiana, preocupações que vêm ganhando renovada atenção no âmbito da estética filosófica (na "estética do dia-a-dia" ou na “estética ambiental”, por exemplo). ${ }^{3}$

Em razão desta predileção nasceu, há alguns anos, o interesse pelo pensamento de Pareyson, o qual se mostra bastante propício à abordagem destas questões, pois tem entre seus traços notórios o esforço de pensar a experiência estética em termos de máxima abrangência. $\mathrm{O}$ filósofo erigiu uma teoria ampla e sistemática, afirmando uma raiz comum da experiência estética: uma atividade - a formatividade - que irmana as mais elevadas e autônomas obras artísticas às mais humildes e triviais manifestações da vida humana. E mais, fê-lo através de uma radicação deste potencial estético numa concepção positiva da pessoa enquanto agente, atuante, conferindo uma base humana, existencial e operativa à produção de realidades esteticamente apreensíveis.

Para Pareyson, a formatividade é a raiz da arte e se encontra em tudo o que o homem faz. Em consonância à sua visão, pode-se dizer, portanto, que "são arte as coisas feitas pelo artista, mas é arte também o mundo das coisas feitas, assim como arte é a vida mesma, a vida que cada um vive". ${ }^{4}$ Tal afirmação se funda, em sua filosofia, numa recuperação e reelaboração da noção antiga de arte como

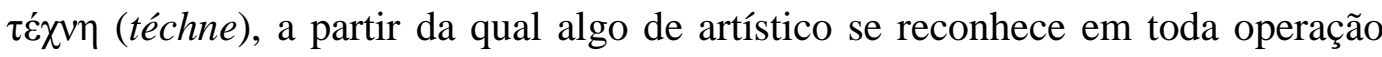
humana, e a qual, matizada, permitirá a eclosão da arte "propriamente dita", como fenômeno autônomo. ${ }^{5}$ Não por acaso, Pareyson compreende a estética a duplo

\footnotetext{
${ }^{3}$ Ver, por exemplo, LEDDY, T., The nature of everyday aesthetics, pp. 3-4;19. Meus primeiros contatos com a estética filosófica, no contexto de uma formação anterior na área do desenho industrial, foram já travados, nesse sentido, à luz de uma preocupação com as manifestações mais “triviais" da experiência estética, de sua inserção na vida e nos afazeres cotidianos.

${ }^{4}$ FINAMORE, R., Arte e formatività: l'estetica di L. Pareyson, p. 11.

${ }^{5}$ É ainda Nunes a recordar que nessa acepção mais antiga e ampla (como téchne) são artísticos "todos aqueles processos que, mediante o emprego de meios adequados, permitem-nos fazer bem uma determinada coisa. (...) Dentro desse significado, cabem tanto aquelas artes da medida e da contagem, quanto as manuais, que possibilitam a fabricação de objetos destinados ao uso, e que saem das mãos dos artífices, e, por fim, as artes imitativas, como a Pintura, a Escultura, a Poesia e
} 
título: por um lado, como uma teoria geral da atividade humana e, por outro, como uma teoria específica da arte, sem separação rígida entre ambas. ${ }^{6}$

Mas, se há um "fazer com arte" que se pode legitimamente encontrar em todo operar, o resultado deste fazer se pode sempre colher numa avaliação estética, a qual pode ser igualmente requerida da realização de qualquer valor. ${ }^{7}$ Pareyson entende a vida humana como constante produção de formas, as quais se oferecem, enquanto tais, à apreciação, de modo que toda obra humana se possa considerar (embora sempre em consonância a seus fins previstos), também sub specie pulchri. No contexto da estética de Pareyson, portanto, filosofia da arte e estética se reencontram: a apreciação do belo e o "fazer com arte" - quando não o "fazer arte" puro e simples - estão indissoluvelmente ligados. ${ }^{8}$

Com uma ressalva, porém: o olhar interessado na abrangente esteticidade que este pensamento promove encontra um aparente obstáculo ali onde esta confina com "objetos" de apreciação estética não oriundos da produtividade humana, e que dela independem. A questão acerca do papel da natureza enquanto parte da experiência estética surge aí e se coloca como ponto extremo na compreensão de uma "esteticidade difusa". ${ }^{9}$ A face mais flagrante desta questão é

a Música” (NUNES, B., Introdução à filosofia da arte, pp. 17-18, grifos do autor). Já Tatarkiewicz salienta a importância do conceito de regra a esta tradicional concepção de arte: fazeres que fossem simplesmente produto da inspiração ou da fantasia, não eram tidos como arte para antigos ou medievais, sendo mesmo a antítese da arte. (Cf. TATARKIEWICZ, Historia de seis ideas: arte, belleza, forma, creatividad, mímesis, experiencia estética, pp. 39-40). Pareyson reivindica a recuperação da noção de téchne, no quadro de uma reinterpretação moderna do conceito de regra, no sentido de sublinhar sua irrepetibilidade e de valorizar o singular concreto (Cf. PAREYSON, L., Conversaciones de estética, pp. 230-231).

${ }^{6}$ Cf. PAREYSON, L., Esistenza e persona, p. 223.

${ }^{7}$ Cf. FINAMORE, R., Arte e formatività, p. 40.

${ }^{8}$ Naturalmente, afirmar a onipresença da experiência estética como experiência do "belo" põe a questão acerca do que efetivamente constitui a beleza, pergunta que recebeu as mais variadas respostas ao longo da história da filosofia, bem como a questão de seu elo (contingente ou necessário) com a arte (pense-se no conceito de "belas-artes"). A resposta pareysoniana, como se verá à frente, busca a identidade comum a todas estas experiências, caracterizando a fruição da arte sempre como uma atividade que culmina numa experiência do "belo", embora se entenda este belo num sentido bastante peculiar, que será discutido posteriormente.

${ }^{9}$ Esta adequada expressão, proposta por M. Ferraris para caracterizar a estética de Pareyson, será retomada outras vezes neste trabalho, sendo então discutida em mais detalhe. 
a pergunta acerca do "belo natural", a qual motivou primeiramente este estudo. Diante do alvorecer, de um animal, de uma montanha, do firmamento, aprecia-se a beleza de coisas que independem do homem; aí, este não se encontra perante seus próprios produtos.

Portanto, a opção pelo estudo da natureza obedeceu ao desejo de salientar este elemento que se mostra como alteridade face ao homem, e logo, como ponto mais extremo da abrangência da esfera estética, estando a natureza (ao menos em certo sentido) mais distante das atividades humanas do que elas entre si. Para Pareyson, a natureza se mostra como algo para além do homem, como outro em relação a ele - sendo, por conseguinte, uma das formas da transcendência que ele vivencia existencialmente, transcendência a qual se mostra "no sentido de que a existência faz sempre a experiência de ter - defronte ou detrás de si, ou sob ou sobre, ou não se sabe onde - limites". 10 Como esclarece o filósofo, "ninguém quererá negar que o homem tem sempre de lidar com alguma coisa que não depende dele e que antes lhe resiste: por exemplo, a natureza, a lei moral, o passado, etc. Fogem a toda tentativa do homem de deles dispor como quer". ${ }^{11}$

Assim, a natureza denota um domínio que confina com o homem e que a ele se opõe e dele se distingue. E, no entanto, alguma consistência e independência se devem reconhecer na mesma. Pois se a estética de Pareyson, marcada pelo viés existencialista, se funda numa filosofia da pessoa, esta é sempre entendida, por outro lado, como aceno e acesso ao ser, como abertura à transcendência, ao que está para além de si e, nesse sentido, rejeita todo subjetivismo. Deve-se compreender aqui, de início, como uma estética que parte da especificidade do formar entre as atividades humanas pode dar conta de uma concepção autônoma do belo natural, que o acolha em sua consistência ontológica própria.

Esta questão, porém, é inseparável de outra, ligada a outra face da teoria da formatividade. É também a partir de uma oposição entre arte (como operar humano em sentido lato) e natureza (como polo complementar ou opositivo a este atuar) que a relação entre ambos os domínios se constituiu num tema fundamental da história da estética, ao qual Pareyson concede grande relevância teórica. Podese confirmá-lo se se adverte como, em um breve artigo acerca da evolução do

\footnotetext{
${ }^{10}$ TOMATIS, F. Pareyson: vita, filosofia, bibliografia, pp. 56-57.

${ }^{11}$ PAREYSON, L., La natura tra estetica e ontologia, p. 13.
} 
conceito de arte, o autor se esmera em apontar a maior ou menor proximidade que este vai entretendo, desde os primórdios da reflexão filosófica e ao longo de sua história, com o domínio da natureza. ${ }^{12}$ Assim, assinala em Aristóteles a aproximação de ambos domínios quanto ao seu caráter de devir, embora distintos quanto às dinâmicas de geração (sob um princípio intrínseco, na natureza) ou produção (sob um princípio extrínseco, na arte) que os separam. E salienta, na aproximação aristotélica do proceder de ambas, o princípio de imitação da natureza, de longa fortuna na história da filosofia. Do mesmo modo recorda, por exemplo, a concepção de arte dos estoicos, que, reunindo numa "arte de viver" todo o âmbito de atividade humana, deixava apenas a natureza como contraponto a esta arte abarcante e total. ${ }^{13}$

A progressiva restrição do termo arte à sua acepção estética, que se verifica a partir da renascença, não impede, entretanto, a continuidade de sua consideração face à natureza. Em paralelo aos preceituários que advogam a imitação da natureza em clave representacional, ganham terreno as reafirmações de cunho aristotélico da arte como imitação do operar da natureza, ressalvadas as diferenças ontológicas entre ambas. Um estreitamento de tal analogia permite a consideração, segundo Pareyson, de uma continuidade entre os dois âmbitos, tal como se encontra em Ficino, por exemplo. Posteriormente, com Kant, esta aproximação se adensa na afirmação de que a natureza é bela se ao mesmo tempo parece ser arte, e de que a arte somente pode ser denominada bela se, embora se tenha consciência de que ela é arte, ela pareça ser natureza, paradigma que ganha corpo com o pensamento romântico, e a partir do qual Pareyson orienta principalmente sua reflexão sobre o tema. ${ }^{14}$

Esta breve digressão histórica é relevante, uma vez que a teoria da formatividade recupera não poucos elementos deste desenvolvimento, admitindo influências clássicas, modernas e contemporâneas. Pareyson buscará conciliar uma concepção abrangente de arte com a ideia de uma arte esteticamente

${ }^{12} \mathrm{O}$ artigo em questão, "Breve historia de um concepto perene", consta apenas da edição espanhola da obra Conversazioni di estetica. (ver PAREYSON, L., Conversaciones de estética, pp. 217-232).

${ }^{13}$ Cf. PAREYSON, L., Conversaciones de estética, pp. 220-221.

${ }^{14}$ Cf. PAREYSON, L., Conversaciones de estética, pp. 227-229; ver também KANT, I., Crítica da faculdade do juízo, p. 162 et seq. 
orientada. E, constatando que "o significado antigo da arte como contraponto ou análogo à natureza ainda está em vigor, embora se prefira exprimir a distinção com os termos 'artificial' e "natural", 15 há de contemplar doravante o lugar da natureza face à criação artística. A teoria da formatividade salienta aí o sentido em que o fazer humano mimetiza um fazer natural, o paralelismo entre as obras forjadas pelo homem e as coisas meramente existentes da natureza e o organicismo que de algum modo se verifica no surgimento de ambas. É a valência "naturalista" que - com base em Kant e, principalmente, em Goethe - Pareyson imprime à sua reflexão estética, retomando a ideia de uma confluência entre os dois domínios.

Por este motivo, a compreensão do lugar da natureza nesta estética passa necessariamente pelos momentos da criação e da fruição da arte. Há um fundamento comum à imitação da natureza pela arte e à possibilidade do belo natural. A questão que mobiliza este estudo, então, é aquela acerca do sentido de que a natureza pode se revestir numa estética de raiz personalista e ontológica, que sustenta a contemplabilidade estética num paradigma formal e entende a pessoa humana como produtora de formas, ao mesmo tempo em que reconhece uma dimensão fundacional que a ultrapassa e solicita, e que acolhe ainda um solidário liame entre natureza e arte. Pergunta-se em que sentido uma teoria da formatividade (entendida como uma atividade humana dentre outras, e conhecida por via de uma análise da experiência) pode chegar a abordar o problema da esteticidade (e da formatividade) da própria natureza.

Posta a questão nestes termos, pode-se retornar à hipótese proposta. Como dito, ancora-se este trabalho num movimento duplo. Parte-se do pressuposto que, a despeito da consideração relativamente pequena que a questão da natureza tem recebido nos estudos da estética pareysoniana e do caráter relativamente descontínuo das referências a ela feitas nas próprias obras do autor, esta é uma dimensão inescapável para uma teoria estética que proponha uma "esteticidade difusa". Contra uma possível consideração da mesma como mero apêndice um tanto incongruente a uma filosofia da "arte" (ainda que muito abrangente), sustenta-se que ela assume importância decisiva para se compreender como a nossa experiência inteira esteja, como o diz Pareyson, "constelada de momentos

\footnotetext{
${ }^{15}$ PAREYSON, L., Conversaciones de estética, p. 224.
} 
estéticos". ${ }^{16}$ E que este tema, por conseguinte, merece um tratamento específico, que o traga ao centro da discussão.

E, uma vez de posse deste norte teórico, pretende-se demonstrar que a compreensão desta "esteticidade da natureza", em meio à discussão dos presumidos elementos "naturalistas" do pensamento do autor, radica-se efetivamente em sua filosofia da pessoa. E que em última análise, portanto, uma formatividade natural deve ser compreendida à luz da formatividade humana. Será o fazer do homem - cujos traços distintivos Pareyson examina em detalhe - a instância paradigmática em analogia à qual se pensará e compreenderá a formatividade da natureza, afirmada categoricamente, mas conhecida apenas indiretamente. Nesse sentido, o "fazer" da natureza se entende por meio da percebida similitude com o fazer do homem, mas contrasta com este enquanto só se conhece enquanto se mostra em certa medida análogo ao que neste se dá de modo evidente. E que, portanto, longe de uma "metafísica da natureza" de sabor clássico, o discurso de Pareyson sobre o formar natural encontra acolhida embora não sem tensões - no seio de seu personalismo ontológico, com uma consequente redução do naturalismo e da fundamentação metafísica que esta face de sua estética, segundo alguns comentadores, pareceria exigir. A imitação da natureza e o belo natural se mostrarão, então, suficientemente coerentes com seu existencialismo personalista e a ele subordinados.

O desenvolvimento das questões tratadas foi estruturado em três capítulos e uma conclusão, cujo teor se descreve em seguida.

O primeiro capítulo, de caráter introdutório, divide-se em dois segmentos. Apresenta de início, em breve esboço, alguns conceitos fundamentais do pensamento de Pareyson, úteis ao entendimento da teoria da formatividade. Em seu segundo segmento, o foco recai especificamente sobre seu pensamento estético. Aí, expõem-se em linhas gerais sua concepção sobre o escopo e os limites da disciplina, bem como algumas notas sobre a influente estética de Benedetto Croce, em diálogo e em resposta à qual se desenvolve em grande medida a reflexão pareysoniana.

O segundo capítulo adentra efetivamente a estética da formatividade, apresentando de início seus conceitos essenciais, no que toca ao fazer artístico. A

\footnotetext{
${ }^{16}$ PAREYSON, L., Estética: teoria da formatividade, p. 196.
} 
definição pareysoniana da arte em sua generalidade e em sua especificação, sua correspondente concepção da obra como forma, bem como sua descrição do processo produtivo são aí examinadas e, posteriormente, relidas à luz da relação que mantêm com a esfera natural. Particularmente, enfatiza-se a recuperação, por Pareyson, da noção clássica da arte como imitação e do papel desempenhado pelo conceito de organismo no que concerne à compreensão da obra de arte e do atuar que a traz à existência, enquanto emulação de um esforço formador da própria natureza.

O terceiro capítulo, por seu turno, opera uma mudança de foco, discutindo a experiência estética da perspectiva do apreciador. Esta se alicerça no conceito de interpretação, o qual é analisado desde suas bases. Do exame das características da interpretação e de seu exercício na arte, passa-se à consideração da mesma como condição de apreensão do belo natural, salientando o relevo, para a compreensão do potencial estético da natureza em Pareyson, de sua reinterpretação de elementos da estética kantiana. Buscam-se aí as bases de uma fundamentação do mesmo esforço formador natural antes referido à produção artística. Analisada a estética sob este duplo aspecto, propõe-se - ao fim do mesmo capítulo - a questão acerca dos fundamentos últimos da relação de solidariedade estética entre natureza e arte, com a discussão dos contributos de Pareyson nesse sentido.

$\mathrm{Na}$ conclusão, por fim, recuperando alguns pontos tratados previamente, discute-se a valência naturalista da estética de Pareyson e sua relação com as dimensões personalista e ontológica de seu pensamento, com o fim de atestar a precedência da consideração pessoal e operativa da formatividade frente a sua extensão ao mundo natural.

O pensamento de Pareyson ainda é pouco conhecido fora da Europa (ou mesmo da Itália) e pretende-se aqui contribuir a um esforço, já em curso há algum tempo, de ampliar sua discussão no Brasil. Isto é feito com base na convicção de que seu valor ultrapassa o contexto espaço-temporal em que surgiu, e de que, quanto ao tema de que este escrito se ocupa, este pode contribuir a uma compreensão mais rica de nossa apreciação - inescapavelmente pessoal - da natureza. Na pesquisa prévia a este trabalho, não se encontraram muitas referências sobre este problema na estética pareysoniana, embora ele seja ocasionalmente contemplado em parte da bibliografia sobre o autor, mesmo 
quando votada a outras searas de seu pensamento. Tendo consciência de que este tema se presta a mais aprofundamentos e clarificações do que os que aqui se puderam fazer, este estudo reconhece seus modestos limites e se propõe como não mais que uma primeira aproximação a uma questão bastante complexa. 


\section{Da filosofia à estética como filosofia}

\section{1.}

\section{Pareyson e a filosofia}

Luigi Pareyson (1918-1991) é um dos mais importantes filósofos italianos do séc. XX. Considerado - junto a Abbagnano, Bobbio e Fabro - um dos introdutores do existencialismo em terras italianas, é tido também como um dos expoentes da hermenêutica, tendo dado seus primeiros contributos a esta disciplina antes ainda das incursões de Gadamer e Ricoeur. Como professor, no contexto da chamada Escola de Turim, foi decisivo na formação de pensadores de prol, como Gianni Vattimo e Umberto Eco, entre outros. Fundou e dirigiu diversos periódicos e coleções filosóficas, colaborou em edições críticas, e principalmente, legou uma copiosa obra escrita (atualmente em curso de publicação, suas obras completas totalizam vinte volumes). ${ }^{17}$ Em seus escritos comparecem, a um só tempo, um pensador original, ocupado com algumas questões filosóficas fundamentais e com os problemas próprios ao seu tempo; e um intérprete e pesquisador minucioso, autor de obras crítico-historiográficas que versam sobre uma ampla gama de temas filosóficos e abarcam ideias e autores da antiguidade ao século XX.

Identificando-se à corrente filosófica existencialista, o pensamento de Pareyson apresenta duas vertentes fundamentais: uma filosofia "sem genitivo", esforço levado a cabo ao longo de toda a vida, e a dedicação específica, por um par de décadas, ao campo da estética. Nesta seara, publicou diversas obras, entre estudos críticos (sobre autores e temas cruciais da história da disciplina) e suas teorizações pessoais, consubstanciadas numa teoria estética própria, a teoria da formatividade.

O presente trabalho, na medida em que se propõe investigar as relações entre arte e natureza no interior da estética da formatividade, apela a um recorte

\footnotetext{
${ }^{17}$ Cf. BLANCO SARTO, P. Hacer arte, interpretar el arte: Estética y hermenéutica en Luigi Pareyson, p. 2; OLIVEIRA, R. G. A obra de arte como um fato hermenêutico-ontológico: a visão de Luigi Pareyson, p. 17.
} 
não só de parte da filosofia de Pareyson, mas a um subsequente recorte de sua estética mesma, relegando a um segundo plano ou mesmo omitindo alguns de seus aspectos indubitavelmente importantes. Apesar disso, de modo a situar esta questão principal no interior do pensamento de Pareyson, e de sua estética em particular, faz-se mister uma exposição prévia de alguns elementos destes, restritos ao mínimo necessário aos propósitos aqui visados.

O próprio Pareyson reconhecia em sua filosofia três períodos distintos. Segundo esta divisão, seu pensamento de juventude se podia caracterizar como um "existencialismo personalista" ou "personalismo ontológico", o qual seria seguido na maturidade por uma "ontologia do inexaurível", marcada por uma visão hermenêutica da relação com a verdade e com o ser tomados sob o signo da inesgotabilidade. Por fim, a última fase de seu pensamento assumiria a feição de uma "ontologia da liberdade", fundada na perquirição da liberdade originária do ser, na experiência religiosa e na experiência do mal. ${ }^{18}$

Esta divisão em períodos é significativa, pois aponta inflexões importantes em seu percurso intelectual. Não obstante, estas etapas se caracterizam mais por diferentes ênfases, mais por aprofundamentos em aspectos distintos das questões norteadoras de seu pensamento, do que por rupturas radicais quanto às posições teóricas gerais e temas tratados. Algumas questões fundamentais alimentarão sua reflexão ao longo de toda a vida, e mesmo sua estética será atravessada pelas questões que de forma mais notável lhe marcaram o labor filosófico. Saliente-se, pois, que a despeito da conveniente periodização, o pensamento de Pareyson é notório pela unidade de seu fio condutor, o qual, segundo Pineri, é

a tentativa de pensar a existência enquanto ela não se reduz ao fechamento no evento singular e particular, mas está exposta à prova da abertura ao ser, e como esta abertura permanece a possibilidade mais própria da existência singular. A fonte de germinação de todo seu percurso filosófico é a explicação do vínculo originário entre existência e transcendência. ${ }^{19}$

Tomatis, no mesmo diapasão, afirma que em todos os momentos o filósofo não fez senão aprofundar uma questão fundamental, qual seja "a da existência como paradoxal coincidência de autorrelação e heterorrelação ou a indivisibilidade de

\footnotetext{
${ }^{18}$ Cf. TOMATIS, F., Pareyson: vita, filosofia, bibliografia, p. 37.

${ }^{19}$ PINERI, R., Une pensée de l'ouverture. Luigi Pareyson, p. 544.
} 
liberdade humana e liberdade divina". ${ }^{20}$ Também delimitando questões fundamentais do pensamento de Pareyson, Ciglia elege a teoria da interpretação e a reflexão sobre a liberdade como dois eixos "absolutamente centrais nas diversas fases da meditação pareysoniana, que desempenham, de todo modo, o papel de elementos de polarização de quase todas as outras temáticas e componentes desta mesma meditação". ${ }^{21}$ Por fim, uma síntese da filosofia de Pareyson se pode obter caso se atente, na mesma, à ênfase posta

na pessoa e na verdade, na liberdade e no ser: surgindo de uma determinada situação pessoal e histórica, a pessoa se dispõe a alcançar o ser e a verdade que estão na origem da realidade. E assim, a filosofia pareysoniana tentará ser a um só tempo concreta e abstrata, prática e teórica. Além disso, ao tratar-se de uma autêntica filosofia existencialista, nela aparecerá de modo contínuo um caráter de risco e incerteza, já que - aparte o poder alcançar a verdade - a pessoa poderia também cair no erro.

Uma breve exposição de alguns temas até aqui perfilados ajuda a contextualizar de modo suficiente o panorama filosófico mais amplo no qual nasce e se insere a estética de Pareyson. $^{23}$

\subsection{1.}

\section{Existencialismo e personalismo}

$\mathrm{O}$ cenário intelectual italiano das primeiras décadas do século XX era dominado pelas filosofias chamadas "neo-idealistas", de ascendência hegeliana, no qual despontavam particularmente as figuras de Benedetto Croce e Giovanni Gentile. Insatisfações e limitações de tal hegemonia já se faziam sentir quando o jovem Pareyson, em meados dos anos 30, inicia seus contatos com a filosofia da existência. Tendo sido formado num contexto espiritualista, o qual já buscava fazer frente a certas tendências idealistas, particularmente gentilianas, de dissolução do singular no interior da vida do espírito, o pensador se aproxima do existencialismo à luz da preocupação de resguardar o finito em sua

\footnotetext{
${ }^{20}$ TOMATIS, F., Pareyson: vita, filosofia, bibliografia, p. 37.

${ }^{21}$ CIGLIA, F. P., Ermeneutica e libertà: l'itinerario filosofico di Luigi Pareyson, p. 11.

${ }^{22}$ BLANCO SARTO, P., Hacer arte, interpretar el arte, pp. 291-292 (grifos do autor).

${ }^{23}$ A exposição que se segue se restringe aos dois primeiros momentos da reflexão pareysoniana, sendo desconsiderada a sua terceira fase (a "ontologia da liberdade"), uma vez que esta sucede temporalmente seu envolvimento com a estética e não se mostra imprescindível à compreensão do tema aqui tratado.
} 
irredutibilidade e dignidade. Como aponta Coppolino, a questão do finito constitui um dos eixos problemáticos da reflexão existencialista - aquele finito, de cuja infinitude o hegelianismo busca "de uma parte apresentar-se como a mais potente e vigorosa exaltação, enquanto de outra representa sua negação ao considerá-lo instrumental em relação à ideia". ${ }^{24} \mathrm{O}$ existencialismo aparece nesse contexto como filosofia da crise do hegelianismo, embora de início propondo soluções que oscilam, para o jovem Pareyson, entre afirmações do finito face ao infinito e considerações do próprio finito em sua suficiência. Ambos os caminhos redundariam, no entanto, numa consideração do finito em termos de negatividade, ainda num quadro de fundo hegeliano. ${ }^{25}$ Pareyson busca uma concepção do finito que, mais que mera revalorização do momento do individual, rejeite sua consideração como mero momento na vida do espírito. Por outro lado, julga insuficientes a consideração da pessoa proposta pelo existencialismo e sua ênfase no caráter absoluto do singular:

Segundo Pareyson, a filosofia da existência, em sua polêmica contra a generalidade idealista, fecha o singular na cegueira da associabilidade e da incomunicabilidade, não realizando o conceito de universalidade inerente ao singular, que é responsável pela sua validade onirreconhecível. Em contrapartida, a filosofia do espírito se volta ao valor universal da pessoa, sem atribuir-lhe, ao mesmo tempo, o caráter de totalidade que lhe compete, enquanto singularidade irrepetível e autônoma. ${ }^{26}$

Por conseguinte, desenvolve seu personalismo como tentativa de superação das insuficiências existencialistas e idealistas, esforço que tem sua primeira culminação com a publicação da obra Esistenza e Persona, na qual

Uma série de problemas, próprios de um personalismo atual, foram atacados (...) mas aqueles sobre os quais mais se demorará a reflexão serão: o homem como existente e situado, o homem como tarefa a si mesmo, como obra da própria atividade, como responsável não só por aquilo que consegue fazer de si mesmo, mas também daquilo que ele é sem que de si dependa, o finito como insuficiente mas não negativo e como positivo mas não suficiente, a distinção e a possível relação de conceitos tão diversos como pessoa, indivíduo e sujeito. ${ }^{27}$

\footnotetext{
${ }^{24}$ COPPOLINO, S., Estetica ed ermeneutica di Luigi Pareyson, p. 21.

${ }^{25}$ Cf. COPPOLINO, S., Estetica ed ermeneutica di Luigi Pareyson, p. 21.

${ }^{26}$ OLIVEIRA, R. G., A obra de arte como um fato hermenêutico-ontológico, p. 68.

${ }^{27}$ CANEVA, C., Bellezza e persona: l'esperienza estetica come epifania dell'umano in Luigi Pareyson, p. 39.
} 


\subsection{2. \\ O conceito de pessoa}

Todos estes temas se articulam em torno do conceito fundamental de pessoa. Este - recorda Caneva - embora tenha admitido historicamente sentidos diversos, manteve sempre uma valência geral como "sujeito de relações". Este aspecto relacional do mesmo ganhou relevo a partir da reflexão cartesiana (enquanto gradualmente se esfumava sua dimensão substancial herdada do medievo), mas então se frisava antes o caráter de relação consigo mesmo - donde a identificação com a ideia do Eu como consciência. Posteriormente, no hegelianismo esta ênfase na consciência seria radicalizada, mas também contraposta pela afirmação, por parte da esquerda hegeliana e do marxismo, de sua relação com os outros e com a natureza. Este aspecto heterorrelacional seria reafirmado e ganharia grande relevo, mais adiante, com a corrente fenomenológica. Pareyson, por seu turno, busca unir as duas instâncias do conceito, entendendo a pessoa - numa perspectiva que remonta a Kierkegaard - como coincidência de relação consigo e com aquilo que a transcende. ${ }^{28}$

Neste sentido, a pessoa se descortina para Pareyson como concreção dialética entre a situação na qual se encontra e a inciativa que ela própria é. Iniciativa e situação são irredutíveis uma à outra, mas ambas determinam-se mutuamente: a iniciativa ajuíza a situação transcendendo-a e a situação é qualificada pela iniciativa que sobre ela opera. Logo, mostram-se como inseparáveis, incindíveis e irmanadas num nexo de unidade e dualidade. Do mesmo modo, a pessoa se revela como união indissolúvel de pólos dialéticos como definitividade e infinidade, necessidade e liberdade, totalidade e insuficiência, dentre outros. ${ }^{29}$

Dá-se a mesma relação, por exemplo, na dinâmica de receptividade e atividade, de particular relevância aqui. Esta oposição corrige e supera a falsa dicotomia - vigente, segundo Pareyson, no racionalismo metafísico - entre passividade e criatividade (uma, a pura atividade sem elementos receptivos, e a outra uma receptividade sem elementos ativos). Se criatividade e passividade se excluem, atividade e receptividade se implicam: deve-se ver, naturalmente,

\footnotetext{
${ }^{28}$ Cf. CANEVA, C., Bellezza e persona, pp. 129-130.

${ }^{29}$ Cf. PAREYSON, L., Esistenza e persona, p. 197 et seq..
} 
passividade na situação (como contexto) e atividade na iniciativa (como decisão e ação). Mas o autor ressalta que toda passividade se resolve em atividade, na medida em que acolhida na iniciativa que a elabora numa realização própria. Ao mesmo tempo, toda iniciativa se mostra como necessidade imposta - exigência em face de uma situação perante a qual a pessoa não pode não agir. Esta distinção se relaciona intimamente a sua compreensão da liberdade, o bem maior da pessoa, que Pareyson entende como "espontaneidade inventiva na exigência: aquela exigência que conduz a pessoa em todo instante da sua história, interpretando aquilo que deve ser a sua singularíssima tarefa, a encontrar os caminhos que a cada vez será conveniente seguir". ${ }^{30}$ Meditando sobre a condição da pessoa, o filósofo atesta que esta "é, sim, liberdade, mas que na base da sua liberdade há uma necessidade inicial, pela qual ela age e decide não podendo não agir e não decidir; o que é signo do seu ser principiado: o homem é iniciativa, mas iniciativa que é, por sua vez, iniciada". ${ }^{31}$ Pareyson julga, enfim, que a pessoa resulta totalmente caracterizada se se a considera como existência, como tarefa, como obra, e como eu:

\begin{abstract}
A pessoa é ao mesmo tempo existência, isto é, história concreta do corporificar-se da iniciativa; tarefa, isto é, coincidência de ideal e dever em uma vocação que é a coerência buscada na vida inteira; obra, isto é, forma vivente e irrepetível dotada de validade absoluta e originalidade exemplar; eu, isto é, substância histórica qualificada por uma responsabilidade essencial, e exercício pessoal da razão universal. $^{32}$
\end{abstract}

Este peculiar conceito de pessoa traz a reboque alguns desdobramentos. De início, ressalte-se que em Pareyson a pessoa afasta qualquer caráter subjetivista ou intimista: contra uma concepção do sujeito que tudo resolve em sua interioridade, a pessoa é inexoravelmente abertura ao outro, um outro que ela mantém em sua independência no ato mesmo em que dele se apropria. ${ }^{33}$ Do mesmo modo, a indivisibilidade da pessoa garante uma presença unânime de todos os seus aspectos. As atividades humanas deixam de ser consideradas de modo estanque e abstrato, em prol de uma visão unitária, segundo a qual é a iniciativa que confere

\footnotetext{
${ }^{30}$ CANEVA, C., Bellezza e persona, p. 36 (grifos da autora).

${ }^{31}$ PAREYSON, L., Esistenza e persona, p. 214

${ }^{32}$ PAREYSON, L., Esistenza e persona, p. 201.

${ }^{33}$ Cf. PAREYSON, L., Verdade e interpretação, p. 73.
} 
ao atuar e ao agir seu direcionamento próprio a cada caso, no que Pareyson chama a unitotalidade da pessoa. ${ }^{34}$

\subsection{3.}

\section{A hermenêutica}

O reconhecimento do caráter interpretativo de toda a sorte de relações entre homem e mundo concede particular importância à hermenêutica na filosofia contemporânea, admitindo várias abordagens segundo diversos pensadores. Como afirma Coppolino, a questão da interpretação põe em relevo a condição humana como situação sempre hermenêutica e, supõe, como premissas de seu processo, duas condições paralelas: de um lado, a autonomia e irredutibilidade do evento ou forma em seu oferecimento como fonte de possibilidades significativas; do outro, a necessária dimensão de finitude e limitação da existência do homem, pois só a um pensamento absoluto seria factível abranger a totalidade do ser. ${ }^{35}$ Os dois aspectos são particularmente enfatizados por Pareyson, pois a interpretação será conhecimento de teor revelativo ao mesmo tempo em que manifestação pessoal, patenteando a limitação de perspectiva irmanada à autonomia do interpretado.

A dimensão hermenêutica é uma constante do pensamento de Pareyson, retornado sempre em novas e mais densas formulações. O filósofo desenvolve, segundo Ciglia, três versões de sua teoria da interpretação. A primeira delas, na virada dos anos 50, parte da exigência, de origem hegeliana, de pensar a filosofia enquanto passível de alcançar a verdade absoluta ao mesmo tempo em que se afirma como historicamente condicionada. Sustentar-se-á na afirmação da posse possível da verdade enquanto exclusivamente aplicável a uma dada situação histórica particular. Mas reconhecendo, no entanto, no caráter universal e na estrutura essencial da pessoa e do âmbito de problemas que esta descortina, um princípio de unificação daquelas situações particulares como instâncias de um problema humano perene. A pessoa é, aí, o fator de articulação entre os aspectos especulativo e condicionado da filosofia, e a interpretação, como dimensão pessoal, aparece juntamente às dimensões veritativa e histórica como um dos elementos essenciais do pensamento e como mediação entre as outras duas.

\footnotetext{
${ }^{34}$ Cf. PAREYSON, L., Esistenza e persona, pp. 213-214.

${ }^{35}$ Cf. COPPOLINO, S., Estetica ed ermeneutica di Luigi Pareyson, pp. 65-66.
} 
Posteriormente ganhará relevo tal, ao ponto de assimilar as demais e identificar-se com o pensamento em sua totalidade. ${ }^{36}$

A segunda elaboração da hermenêutica pareysoniana, desenvolvida no campo da reflexão estética e partindo da noção de intuição, afirmará a comensurabilidade e adequação mútua dos polos da relação de conhecimento sob a égide da noção de forma - entendida como totalidade orgânica que responde tanto pelo caráter do objeto conhecido quanto da pessoa cognoscente - e será, a partir daí, estendida de modo a englobar o conhecimento das formas históricas, sociais, naturais, culminando numa abrangente "gnoseologia da interpretação". Porém, com o prosseguimento deste processo de ampliação e universalização, pôr-se-á a questão se, abandonadas as realidades marcadas por um definindo perfil entitativo - e que se apresentam, logo, como "forma" -, a interpretação poderia, sob o mesmo paradigma conceitual, dar conta do conhecimento das realidades últimas, a saber, da relação primordial da pessoa com a verdade e o ser. ${ }^{37}$

A partir desta exigência, desenha-se a derradeira versão da teoria da interpretação, tal como formulada na obra Verdade e Interpretação: a noção de forma - embora sendo, segundo Pareyson, um finito que inclui um infinito - se mostra problemática para circunscrever a verdade do ser. Paralelamente à crescente presença, no pensamento do autor, de elementos teóricos afins às ideias de transcendência abissal e de diferença ontológica (e patenteando um aporte renovado das influências de Jaspers, Kierkegaard e Heidegger), o polo "objetivo" perde em delimitação. Marcando a cada vez mais ubíqua presença do ser na especulação de Pareyson, o estatuto formal permanece somente no âmbito do intérprete, marcando o abismo que o separa deste interpretado extremo. À homogeneidade da relação forma-forma na concepção prévia da interpretação dá lugar uma heterogênea relação verdade-formulação - ressalvando-se que esta diferença nunca é tão radical a ponto de impedir a relação solidária entre as duas instâncias. ${ }^{38}$ É sobretudo a partir desta concepção de interpretação que se pode

\footnotetext{
${ }^{36}$ Cf. CIGLIA, F. P. Ermeneutica e libertà, pp. 107 et. seq.

${ }^{37}$ Cf. CIGLIA, F. P. Ermeneutica e libertà, pp. 11; 199-200; 204. Há uma unificação entre as noções de verdade e ser em Pareyson, podendo-se entender a verdade como o ser enquanto dado a conhecer (Cf. OLIVEIRA, R. G. A obra de arte como um fato hermenêutico-ontológico, p. 115).

${ }^{38}$ Cf. CIGLIA, F. P. Ermeneutica e libertà, pp. 206. Nesta introdução geral ter-se-á em vista sempre esta última teoria da interpretação, a mais abrangente e mais marcadamente ontológica.
} 
entender o predomínio da especulação ontológica no período maduro da filosofia de Pareyson.

\subsection{4.}

\section{O ser e a verdade}

A pessoa institui-se, como visto acima, em termos de relação consigo e com a transcendência. Com a crescente ênfase posta em seu caráter heterorrelativo, a situação na qual a iniciativa pessoal se insere passa a se mostrar cada vez mais como abertura, como presença estimulante que independe do homem e que este deve saber auscultar e acolher. Como já afirmara o pensador, a situação (como contraposta à iniciativa) nunca é colocação meramente histórica, mas só o é por ser, antes e fundamentalmente, colocação metafísica - a abertura ao outro é relação com o ser, de modo que "a atividade do homem contém o exercício de sua liberdade e ao mesmo tempo a presença operosa e fecunda de uma atividade ulterior". ${ }^{39}$ Aprofundando esta relação, e sinalizando o gradual relevo que então adquirem os elementos hermenêutico-ontológicos, especifica-se a dimensão da pessoa como "perspectiva sobre a verdade" e "relação com o ser", relação que não se confunde com uma faculdade, habilidade ou propriedade do homem, mas que constitui intimamente o seu ser mesmo. Fabris, remontando à distinção entre irrelatividade e relatividade encontrável nas primeiras obras de Pareyson recorda que

Um termo - a pessoa - está na relação só enquanto "é" esta mesma relação. E pode sê-lo porque sua estrutura consiste precisamente na existência: como coincidência de autorrelação e heterorrelação, de relação com si e relação com outro. $O$ outro termo - a verdade, o ser - está na relação, por outro lado, só na medida em que

\footnotetext{
Nos capítulos subsequentes, dedicados à formação e à interpretação na arte e na natureza, nos quais o paradigma formal se coloca como elemento fundamental dos problemas tratados, a atenção recairá, na maior parte do tempo, sobre a segunda formulação da hermenêutica pareysoniana, na qual o problema estético encontra sua ambiência própria. Ressalte-se que não há contradição entre as versões, mas continuidade e aprofundamento, uma vez que o paradigma formal permanece válido em seus justos limites. A nova mirada pareysoniana desemboca numa ontologia "que transcende os limites da forma sem anulá-la, senão potencializando-a ontologicamente em sua vocação formal" (GIMÉNEZ-SALINAS, C., Las principales cuestiones hermenéuticas de Luigi Pareyson, p. 115).

${ }^{39}$ PAREYSON, L., Esistenza e persona, p. 235.
} 
"põe" esta mesma relação. Este então é não-relativo e inobjetivável enquanto não pode ser reduzido a tal relação nem pode jamais ser resolvido nesta. ${ }^{40}$

O ser, aqui, não será jamais hipostasiado, mas entendido como radicação fundamental do pensamento e da ação do homem, como uma "presença sem figura" que, contudo, exerce aquele estímulo à operosidade própria da pessoa, um reclamo "tão profundo que é inseparável dos atos que suscita e indissociável da resposta que desperta" e ao mesmo tempo "tão peremptório que é irredutível à atividade humana e a ela bem presente, como seu início e sua norma". ${ }^{41}$ Donde a representação metafórica do mesmo em termos de "fonte" "nascente" e termos correlatos.

Esta concepção ontológica não deve impedir, porém, um discurso sobre o ser, que deve ser admitido, na filosofia, como

não-objetivável no nosso discurso objetivante; podemos falar do ser com um discurso, com uma filosofia que não seja mais construção conceitual, que não seja mais construção subjetivista de entidades abstratas, mas que seja ao invés uma filosofia hermenêutica, uma filosofia que escute, que ponha na palavra através da escuta aquilo que é o outro de si, aquilo que ela mesma não determina e não constrói, mas somente pode acolher, quase a posteriori. ${ }^{42}$

Evidencia-se, deste modo, em que sentido uma ontologia do inexaurível implica uma filosofia da interpretação e como esta pode aspirar à verdade. Sendo a relação ontológica originária, igualmente o será a interpretação, de modo que esta terá necessariamente relevo ontológico na mesma medida em que a relação ontológica será sempre hermenêutica. Igualmente, e por sua própria radicação ontológica, a interpretação estará intrinsecamente ligada à verdade. É o que leva o filósofo a afirmar que "da verdade não existe senão interpretação e que não existe interpretação senão da verdade". ${ }^{43}$ Mas recorde-se que a verdade deve ser entendida como fonte, e não como meta, como a instância a partir da qual se erige o pensar e que se colhe em todo atuar humano que lhe seja sensível. ${ }^{44}$

\footnotetext{
${ }^{40}$ FABRIS, A. apud GIMÉNEZ-SALINAS, C., Las principales cuestiones hermenéuticas de Luigi Pareyson, pp. 119-120.

${ }^{41}$ PAREYSON, L., Verdade e interpretação, p. 38.

${ }^{42}$ TOMATIS, F. Pareyson: vita, filosofia, bibliografia, p. 46.

${ }^{43}$ PAREYSON, L., Verdade e interpretação, p. 51 (grifos do autor).

${ }^{44}$ Não só o esforço especificamente teorético se liga à verdade, mas também se a pode alcançar na arte, na moralidade, desde que em cada uma dessas dimensões se respeite o liame originário entre pessoa e verdade - inclusive porque, como vínculo originário, a verdade precede a distinção entre
} 
A verdade para Pareyson é "nascente e origem" mais que objeto de busca e exclui seja a total explicitação de tipo racionalista e hegeliano, seja o ocultamento e o silêncio próprios da ontologia negativa e do inefabilismo místico de tipo heideggeriano. A verdade se concede à sua formulação, mas sempre reservando-se, enquanto é assim presente no interior daquela insubstituível relação pessoal da qual não prescinde, mas se oferece sempre na sua inobjetivabilidade e ulterioridade. ${ }^{45}$

Deste modo, Pareyson busca unificar as visões antitéticas de um caráter especulativo e veritativo do pensamento e a condicionalidade pessoal e histórica do pensar. Este, para além de seu inescapável condicionamento (seu elemento expressivo), é também formulação singular da verdade do ser (seu aspecto revelativo). Esta possibilidade do pensamento é pródiga em consequências, estando na base, por exemplo, da veemente apologia pareysoniana da filosofia, que tem aí seu potencial especulativo afirmado e protegido contra certo historicismo que redundaria em relativismo. ${ }^{46}$ Pois a perspectiva inevitável a partir da qual se erige uma interpretação não macula necessariamente o que há de veritativo da mesma:

$\mathrm{Na}$ interpretação, a originalidade, que deriva da novidade da pessoa e do tempo, e a originariedade, que provém da primitiva relação ontológica, são indivisíveis e coessenciais. A interpretação é aquela forma de conhecimento que é ao mesmo tempo e inseparavelmente veritativa e histórica, ontológica e pessoal, revelativa e expressiva. ${ }^{47}$

A verdade se dá no interior das inúmeras formulações interpretativas que dela se propõem. Se "o único modo de colher toda a verdade é o de possuí-la como inexaurível", 48 a verdade estará inteira em cada formulação, embora permitindo (e solicitando) um aprofundamento infinito. Não estará detrás do discurso ou cifrada, ou nele enigmaticamente entremeada, mas se descortinará integralmente a partir daquele ângulo sob o qual é captada, enquanto se entrega sob aquele particular modo de ver. Estará inteira na formulação sem jamais, porém, reduzir-se a ela. Será a um só tempo sempre presente e sempre ulterior. ${ }^{49}$

as várias modalidades de atividades humanas (cf. PAREYSON, L., Verdade e interpretação, p. 116).

${ }^{45}$ CANEVA, C., Bellezza e persona, p. 48.

${ }^{46}$ Cf. PAREYSON, L., Verdade e interpretação, pp. 7-9.

${ }^{47}$ PAREYSON, L., Verdade e interpretação, pp. 51-52 (grifos do autor).

${ }^{48}$ PAREYSON, L., Verdade e interpretação, p. 79 (grifos do autor).

${ }^{49}$ Cf. PAREYSON, L., Verdade e interpretação, p. 71. 
Naturalmente, partindo-se da liberdade humana assaz prezada pelo filósofo, deve-se lembrar que este conúbio com a verdade não é de modo algum necessário ou garantido, e que Pareyson admite os perigos inerentes à empreitada. Se se desconhece ou rejeita aquela solidariedade originária entre pessoa e ser, dois riscos se imiscuem, a saber: o da insolente sobreposição da pessoa sobre a verdade, com o consequente obscurecimento do tempo e de nós a nós mesmos; ou, no polo oposto, a falaz descoberta de uma pretensa verdade independente e descolada da situação concreta, o que se dá quando se considera essa mesma situação como um obstáculo à busca da verdade e não como o seu único caminho possível, o único órgão de acesso à mesma. ${ }^{50}$

\section{2.}

\section{Pareyson e a estética}

A reflexão original de Luigi Pareyson no terreno da estética se encontra em sua teoria da formatividade, a qual recebeu sua formulação mais completa e abrangente na obra de mesmo nome vinda a lume em 1954, e que seria objeto de inúmeros aprofundamentos e clarificações em obras subsequentes do autor, por cerca de vinte anos. ${ }^{51}$ Algumas breves notas acerca da compreensão pareysoniana quanto ao objetivo e natureza da estética, bem como algumas breves linhas acerca da estética crociana serão de proveito, porque permitem enquadrar de modo mais coerente o escopo da teoria da formatividade.

\footnotetext{
${ }^{50}$ Cf. FINAMORE, R. Il discorso sull'essere di Luigi Pareyson, p. 3.

${ }^{51}$ Estética: teoria da formatividade é constituída, como, aliás, a maior parte das obras de Pareyson, de uma série de artigos originalmente aparecidos separadamente em periódicos especializados. No caso da obra em questão, compunham-na escritos que vinham sendo publicados já desde 1950. A obra seria republicada numa segunda edição, revista, em 1960. As outras obras em que desenvolveu sua teoria estética foram Teoria dell'arte (1965), I problemi dell'estetica (1966) e Conversazioni di estetica (1966), esta última unindo breves exposições teóricas a artigos de cunho crítico-historiográfico. A obra Teoria dell'arte aparece neste trabalho citada a partir de sua republicação, juntamente a I problemi dell'estetica, no volume 10 das obras completas de Pareyson (Problemi dell'estetica I. Teoria, Milano, Mursia, 2009). Ver referências bibliográficas.
} 


\subsection{1.}

\section{A estética como filosofia inteira}

Num período entendido por Pareyson como pródigo em iniciativas tendentes a deslegitimar a abordagem propriamente filosófica sobre a arte em prol de "estéticas empíricas", a rejeitá-la em benefício de discursos concorrentes sobre o fenômeno artístico - de caráter historiográfico, sociológico ou programático, por exemplo -, a tarefa de justificar o próprio empreendimento não se mostrava excessiva. ${ }^{52}$ Ademais, como o próprio Pareyson ressalta, "o primeiro problema da estética é o que diz respeito à própria estética: sua natureza, seus limites, suas incumbências, seu método". 53

Pareyson defende a especificidade e irredutibilidade do discurso estético em relação aos demais discursos referentes à arte. A estética, assim, se não se pode pretender o único discurso acerca do fenômeno artístico, não se pode igualmente subtrair em benefício daqueles discursos aos quais falta o elemento especulativo que por sua vez a define e singulariza. O elemento especulativo, por outro lado, não se pode absolutizar e autonomizar, esquecido de que não há especulação sem referência ao concreto: é sempre ao caráter problemático do real que o pensamento deve fazer frente. A estética só encontra sua razão de ser, portanto, como especulação que busca o contato com a experiência concreta com vistas a penetrar-lhe o sentido.

Defender o pendor simultaneamente especulativo e concreto (ou seja, tendente à universalidade e aderido à experiência) da estética é afirmar seu caráter estritamente filosófico, dado que, no entender de Pareyson, é próprio do esforço filosófico haurir, a partir do contato com a experiência, conclusões universais que por sua vez retornem à experiência, de modo a iluminá-la e esclarecê-la. Por seu método e olhar, por sua atenção à universalidade, a estética não será uma seção ou capítulo da filosofia, de menor alcance ou exigência, mas "a filosofia inteira concentrada sobre os problemas da beleza e da arte". ${ }^{54}$ Assim sendo, a estética jamais se poderia resumir à mecânica dedução de seus conteúdos a partir de uma filosofia pressuposta ou à mera catalogação, avaliação ou descrição empírica de

\footnotetext{
${ }^{52}$ Cf. PAREYSON, L. Conversaciones de Estética, pp. 121-123.

${ }^{53}$ PAREYSON, L., Os problemas da estética, p. 1.

${ }^{54}$ PAREYSON, L., Estética: teoria da formatividade, p. 17.
} 
seus objetos. A história da arte e das técnicas, a sociologia ou a psicologia da arte não podem, pois, se travestir em estética (logo, em filosofia), constituindo-se antes em aspectos da mesma experiência estética que fornece material e estímulo à reflexão filosófica. ${ }^{55}$

Do mesmo modo, as poéticas e a crítica devem ser distinguidas da estética, na medida em que ambos discursos trazem um caráter normativo: uma poética consiste num determinado gosto pessoal ou epocal convertido em programa de arte; a crítica, por sua vez, enquanto discurso sobre experiências artísticas particulares, supõe a própria normatividade particular segundo a qual tais experiências se constituíram. Poética e crítica são para Pareyson, não só importantes, mas essenciais para a prática artística e sua difusão e compreensão, mas não alcançam - por sua natureza mesma - o grau de universalidade que se requer da estética. Incluem-se ambas como aspectos daquela mesma experiência sobre a qual se debruça o filósofo. Assim, a estética entretém, com todos esses saberes particulares sobre a arte, relações análogas às que mantém com a própria arte. $^{56}$

Para além do advogado contato com a experiência, a estética de Pareyson se volta também ao diálogo com a tradição filosófica, salientando a importância da história da estética para sua especulação teórica, patente em seus escritos críticos sobre a matéria. ${ }^{57}$ Também se verifica, em seu método expositivo, o interesse em enquadrar suas propostas no quadro mais amplo das discussões em curso, muitas vezes estruturando sua argumentação em face às posições extremadas e antitéticas a que um dado problema estético deu margem, buscando a seguir uma via de mediação entre estas. ${ }^{58}$

${ }^{55}$ Cf. PAREYSON, L., Os problemas da estética, pp. 4-6; Estética: teoria da formatividade, pp. 17-20.

${ }^{56}$ Cf. PAREYSON, L., Os problemas da estética, pp. 11-13.

${ }^{57}$ Cf. BLANCO SARTO, P., Hacer arte, interpretar el arte, p. 41. Recorde-se que Luigi Pareyson foi professor de estética na Universidade de Turim a partir de 1945, e ao longo de cerca de vinte anos. Esse período marca também o de seu envolvimento crítico e criativo com a estética filosófica, à qual praticamente não mais se dedicou depois (cf. D'ANGELO, Il ruolo di Luigi Pareyson nell'estetica italiana del Novecento, p. 73).

${ }^{58}$ Este procedimento, que se poderia confundir com um ecletismo conciliatório, aponta em verdade, segundo Carchia, para o caráter agonístico da estética pareysoniana, radicado em seu existencialismo: "em Pareyson, a constante evidenciação dos extremos através dos quais a 
Antes de se adentrar a teoria de Pareyson, no entanto, deve-se examinar, ainda que brevemente, a estética de Benedetto Croce, solo sobre o qual se desenvolveu quase toda a estética italiana (e em grande medida a europeia) na primeira metade do século XX.

\subsection{2.}

\section{O pano de fundo: a estética de Croce}

A reflexão estética de Pareyson se desenvolve tendo como alicerces as exigências teoréticas impostas pelos resultados de seus esforços paralelos no âmbito de uma filosofia "geral”, cujo desenvolvimento se esboçou no início deste capítulo. Daí a relevância particular que na sua estética vão assumir noções como as de pessoa, iniciativa, ou o binômio receptividade/atividade, dentre outras, inscrevendo a teoria da formatividade no seio do personalismo ontológico pareysoniano. Mas, igualmente, seu pensamento nesta seara dialoga e responde em grande medida às exigências oriundas da estética de Benedetto Croce - a qual, segundo o próprio Pareyson, ainda no imediato pós-guerra (período de suas primeiras incursões no campo da estética) constituía o paradigma e a referência fundamental no ambiente intelectual italiano, a despeito das suas carências e limitações que, a seu ver, já se faziam então sentir. ${ }^{59}$

A estética de Pareyson assume papel de destaque, assim, na renovação da estética italiana do século XX, especialmente por se constituir, no entender de D’Angelo, como a primeira estética sistemática formulada em oposição ao

argumentação se desenreda visa, antes que à sua confutação, a apropriar-se da justa exigência que está no fundo de cada um. Nasce daqui toda a riqueza, a fecundidade, a tensão do seu discurso" (CARCHIA, G., Esperienza e metafisica dell'arte: l'estetica di Luigi Pareyson, pp. 76-77).

${ }^{59}$ Cf. PAREYSON, L., Estética: teoria da formatividade, p. 9. A citação em questão consta de um novo prefácio para a obra, escrito por Pareyson para uma sua reedição em 1988. Paolo D’Angelo ressalta que esta referência explícita ao domínio crociano, muito posterior à publicação original da obra, marca um distanciamento temporal que permitia ao autor, de modo menos problemático, situar historicamente sua estética em relação à de Croce, enquanto no corpo de seu tratado, em verdade, as referências a este pensador são raras, destacando-se a abordagem pareysoniana mais pela reproposição das questões em nova clave que pela polêmica direta (ver D'ANGELO, P. Il ruolo di Luigi Pareyson nell'estetica italiana del Novecento, p. 61). A primeira aproximação de Pareyson aos temas de estética, intitulada Arte e persona, discurso inaugural ao seu primeiro curso de estética, data de 1946 (Cf. TOMATIS, F., Pareyson: vita, filosofia, bibliografia, pp. 21; 69). 
pensamento crociano: sistemática por, assim como a de Croce, abraçar organicamente todos os principais problemas da disciplina; opositiva por romper com a continuidade da estética crociana, afastando-se desta não somente nas soluções alcançadas, mas também nos pontos de partida e nas próprias questões que se tomam em seu interior como mais relevantes. ${ }^{60}$

Nesse sentido, tanto para a melhor compreensão das linhas gerais da estética da formatividade, quanto para a discussão de aspectos particulares da mesma (como o de que se ocupa este estudo) faz-se mister o confronto com alguns temas afins na estética crociana. A seguir serão expostos alguns princípios fundamentais da estética de Croce, reservando-se a discussão de outros de seus aspectos para os capítulos subsequentes, quando da abordagem dos temas da estética pareysoniana que lhes correspondem ou se lhes opõem.

\subsubsection{1. \\ Arte e intuição}

O neo-idealismo crociano afirma a realidade única do espírito, para além do qual nada existe, dado que nada resta se, àquilo que lhe parece exterior, se subtraem as determinações estéticas e lógicas que se lhe apõem. A filosofia é, enquanto ciência do espírito, o mais concreto dos saberes, pois se debruça sobre o todo da realidade tal qual se dá, enquanto as demais "ciências" (como as naturais, por exemplo) operam com base em abstrações desta realidade unitária, convenientes a seus

\footnotetext{
${ }^{60}$ Cf. D’ANGELO, P. Il ruolo di Luigi Pareyson nell'estetica italiana del Novecento, pp. 59;61, e a nota anterior. Em relação ao caráter "anti-crociano" da estética de Pareyson, ao qual D'Angelo faz referência, seu parecer não é compartilhado por outros comentadores. Muitos salientam, por exemplo, os elementos comuns a ambas e os pontos de possível conciliação. Givone, por exemplo, pensa-a mais como pós-crociana que anti-crociana e Ferraris enxerga mesmo em instâncias polêmicas algumas possibilidades de conciliação (ver GIVONE, S., Historia de la estética, p. 151; FERRARIS, M., Un'estetica senza opere, p. 88). Sainati vê na estética de Pareyson uma "adesão distante" à herança crociana (ver SAINATI, V., Discorso critico sulla teoria della formatività, $\mathrm{p}$. 343). Deve-se recordar que, para além do esforço de revisão, a estética de Pareyson tem na de Croce um constante ponto de referência e estímulo de desenvolvimentos, e que o próprio autor afirma que "a filosofia crociana disse sobre a essência da arte palavras tão verdadeiras, que para além dessas é muito difícil proceder e para antes destas não é possível retornar" (PAREYSON, L., Problemi dell'estetica I. Teoria, p. 101).
} 
propósitos particulares. ${ }^{61}$ A estética, no entanto, aparece em tal sistema como filosofia, na medida em que se volta, como se verá, sobre um dos momentos da vida do espírito; neste sentido, ela é a filosofia toda e da filosofia não se pode nunca separar, o que salienta também a importância absolutamente crucial de que a arte gozará para Croce. ${ }^{62}$

A ideia dominante da estética de Croce consiste na afirmação da arte como intuição, entendida como produção de imagens dissociada de juízos de realidade e, portanto, anterior à percepção (que suporia tal juízo). A intuição seria também anterior ao conceito, pois é "forma auroral do espírito", e se reduz à imagem em sua autossuficiência:

Intuição significa, precisamente, indistinção de realidade e irrealidade, a imagem em seu valor de mera imagem, a idealidade pura da imagem; e ao contrapor o conhecimento intuitivo ou sensível ao conhecimento conceitual ou inteligível, a estética à noética, visa-se a reivindicar a autonomia desta forma de conhecimento, mais simples e elementar, que foi comparada ao sonho (ao sonho, bem entendido, não ao sono) da vida teorética, relativamente ao qual a filosofia seria a vigília. ${ }^{63}$

A arte (intuição) é, pois, conhecimento (embora pré-conceitual). Mas é também expressão, pois, no entender do filósofo, intuição e expressão são inseparáveis. Contra a compreensão do fazer artístico em termos de um momento de "concepção" e de outro momento "técnico", Croce sustenta que a autêntica intuição é imagem e, portanto, expressão: “um pensamento é para nós um pensamento se for formulável em palavras; uma fantasia musical só quando se concretiza em sons; uma imagem pictórica quando for colorida". ${ }^{64}$ A figuração interior é sempre já expressiva. Se um poeta ainda busca as palavras de seu poema, é porque ainda não o intuiu; a intuição é imagem e, logo, conteúdo expresso. Exatamente por isso, aliás, Croce nega que a arte seja, em qualquer medida, um fenômeno físico, já que se resolve inteira na interioridade do espírito.

Contra o que considera a falsa oposição entre classicismo (e sua ênfase na adequada representação) e romantismo (e seu foco na efusão sentimental), Croce afirma que "o que dá coerência e unidade à intuição é o sentimento: a intuição é

\footnotetext{
${ }^{61}$ Cf. CARR, H. W. The philosophy of Benedetto Croce: the problem of art and history, pp. 12-13.

${ }^{62}$ Cf. CROCE, B. Breviário de Estética; Aesthetica in nuce, p. 166.

${ }^{63}$ CROCE, B. Breviário de Estética; Aesthetica in nuce, p. 41.

${ }^{64}$ CROCE, B. Breviário de Estética; Aesthetica in nuce, p. 58.
} 
verdadeiramente intuição porque representa um sentimento, e só dele e sobre ele pode surgir". ${ }^{65}$ A gênese da obra de arte se dá como sentimento feito imagem, e por esta razão se pode dizer - embora incorrendo numa tautologia ou num pleonasmo - que a arte consiste numa intuição lírica. A "síntese a priori estética" que o autor põe no surgimento da obra de arte corresponde à síntese de sentimento e imagem na intuição, e leva-o a afirmar, parafraseando Kant, que "o sentimento sem imagem é cego e a imagem sem o sentimento é vazia". 66

\subsubsection{2.}

\section{A arte no sistema do espírito}

Como aludido acima, a arte é para Croce uma das categorias da vida do espírito, e a estética um ramo da filosofia. Esta se resolve em ciência da intuição pura, e fazse a primeira etapa de uma ciência integral da realidade. Tal sistematização das atividades do espírito - e propriamente atividades, pois mesmo o conhecimento não se resume nunca a simples contemplação passiva - compartimenta o todo em uma esfera teorética e em uma esfera prática. A esfera teorética divide-se em intuição (arte, conhecimento do particular) e conceito (filosofia, conhecimento do universal) e a esfera prática na vontade particular (economia, desejo do particular) e vontade geral (ética, desejo do universal). Conhecer e agir, cada qual com suas duas subdivisões, legam os quatro conceitos puros (beleza, verdade, utilidade, bondade) que esgotam o real. ${ }^{67}$

Estas formas se põem numa relação gradual. Se o domínio lógico depende do estético (como o conceito supõe a imagem), o estético dele não depende; o domínio econômico supõe o estético e o lógico e assim sucessivamente, no que Croce chama o "sistema do espírito". ${ }^{68}$ Tem-se, na verdade, um círculo (ou antes:

\footnotetext{
${ }^{65}$ CROCE, B. Breviário de Estética; Aesthetica in nuce, p. 50.

${ }^{66}$ CROCE, B. apud CANEVA, C. Bellezza e persona, p. 60.

${ }^{67}$ Cf. CARR, H. W. The philosophy of Benedetto Croce: the problem of art and history, p. 8; GIVONE, S., Historia de la estética, p. 142. Esta divisão espelha a estruturação das obras capitais em que se expõe o sistema crociano: Estetica come scienza dell'espressione e linguistica generale (1902), Logica come scienza del concetto puro (1905) e Filosofia della pratica (1909), que engloba os domínios econômico e ético (cf. ibidem).

${ }^{68} \mathrm{Cf}$. CROCE, B. Estetica come scienza dell'espressione e linguistica generale, p. 71.
} 
uma espécie de espiral) das formas do espírito, mutuamente implicadas: a imagem, elaborada em percepção alcança o patamar lógico e histórico do conhecimento intelectivo, o qual suscita o pendor à ação que se traduz na vida econômica e moral. Estas, por seu turno, enquanto transformam a realidade, constituem-na em novo estímulo e matéria a ulteriores intuições. Das formas do espírito pode-se dizer que

nenhuma é real, porque só é real a atividade de todas aquelas atividades, que não está em nenhuma delas em particular: das várias sínteses que fomos sucessivamente distinguindo - síntese estética, síntese lógica, síntese prática -, a única real é a síntese das sínteses, o Espírito que é o verdadeiro Absoluto, o actus purus. Mas de outro ângulo e pela mesma razão, todas são reais, na unidade do espírito, no eterno curso e recurso, que é a sua eterna constância e realidade. ${ }^{69}$

Da identificação radical de arte e intuição, e do destaque desta como forma particular do espírito decorrem algumas particularidades da estética de Croce. Por um lado, afirma-se o caráter artístico de toda intuição, não havendo diferenças qualitativas entre quaisquer delas. $\mathrm{O}$ que distingue - apenas quantitativamente as que comumente chamamos artísticas é sua extensão e complexidade, embora se reduzam à mesma expressão de impressões:

No exprimir plenamente certos estados de ânimo complexos, há os de maior aptidão, mais frequente disposição, (...) aos quais chamamos, na linguagem corrente, artistas; algumas expressões assaz complicadas e difíceis são conseguidas mais raramente e a estas chamamos obras de arte. ${ }^{70}$

Daí decorre também a identificação que se dá entre artístico e estético: a beleza para Croce se identifica com a expressão ao ponto da sinonímia dos termos, sendo apanágio exclusivo da arte. Por isso, o filósofo restringe sua possível atribuição aos demais âmbitos ao papel de metáforas a indicar seu eventual caráter de sucesso ou valor. ${ }^{71}$ Depreende-se também do exposto a rigorosa afirmação crociana da autonomia da arte, sua distância em relação a outras manifestações espirituais. A arte só pode ser avaliada segundo seus próprios termos e toda consideração a partir de outro ponto de vista descura o elemento artístico. Donde a exclusão, na abordagem da arte, da técnica material (relegada à esfera prática), da crítica (atribuída ao conhecimento intelectual que ultrapassa o momento estético),

\footnotetext{
${ }^{69}$ CROCE, B. Breviário de Estética; Aesthetica in nuce, p. 78.

${ }^{70}$ CROCE, B. Estetica come scienza dell'espressione e linguistica generale, pp. 16-17

${ }^{71}$ Cf. CROCE, B. Estetica come scienza dell'espressione e linguistica generale, pp. 91-92.
} 
das categorizações, classificações, formas fixas, gêneros e tipologias artísticas (tomados como exteriores ao fato estético e apenas úteis a sua ordenação ou comparação exterior - para fins didáticos, por exemplo).

Se as normas, estilos e classificações são sempre exteriores à arte, se as intuições como tais são sempre irredutíveis, pois sintetizam um estado de ânimo individual, resta a questão acerca das possibilidades de relação e ligação entre as obras frente à aparente atomização insular das mesmas. Se não é possível compartimentar verdadeiramente as obras em escolas ou gêneros, dado que "entre o universal e o particular não se interpõe filosoficamente nenhum elemento intermediário" de modo que "uma pintura se distingue de outra pintura não menos que de uma poesia", 72 deve-se buscar um distinto fator de unificação. Para Croce o único liame concreto entre as obras de arte é a história, na qual cada uma assume o seu lugar próprio enquanto momento singular e autônomo:

\begin{abstract}
Na história, que vai ficando cada vez mais rica e determinada, e não nas pirâmides de conceitos empíricos, que vão ficando mais e mais vazias quanto mais se elevam e estreitam, acha-se a ligação de todas as obras de arte ou de todas as intuições, porque na história elas aparecem organicamente conexas, como etapas sucessivas e necessárias do desenvolvimento do espírito, notas cada qual do eterno poema que harmoniza em si todos os poemas singulares. ${ }^{73}$
\end{abstract}

\title{
1.2.2.3.
}

\section{Arte e natureza em Croce}

As relações entre arte e natureza na estética de Croce assumem conotação negativa. O filósofo rejeita qualquer dimensão naturalista em sua doutrina da arte e da beleza como intuição, tomando por absurda a ideia de uma beleza física. Assim, na arte, por exemplo, a justaposição da dimensão prática à estética no ato de dar corpo à obra não confere dignidade estética àquela dimensão, sendo a obra puramente espiritual. O que se chama, ainda que impropriamente, beleza física na arte ou na natureza é a realidade físico-material do mero estímulo à produção ou reprodução estética.

O filósofo napolitano denuncia o que toma como um falso dualismo entre espírito e natureza, como duas ordens de realidade distintas, bem como a posterior tentativa de, por meio de uma espiritualização da natureza, reintegrá-la a uma

\footnotetext{
${ }^{72}$ CROCE, B. Breviário de Estética; Aesthetica in nuce, p. 67.

${ }^{73}$ CROCE, B. Breviário de Estética; Aesthetica in nuce, p. 69.
} 
visão unificada. Alternativamente, considera que a realidade é una, e se reduz ao espírito. E se se pode efetivamente pensá-la caso a caso, segundo os modos quer do espírito e da vida, quer sob os de matéria e mecanismo, esta segunda consideração responde não ao cerne do real, mas a uma sua consideração de ordem unicamente prático-econômica. ${ }^{74}$

Para o filósofo napolitano, a experiência da natureza não seria comparável ou aproximável daquela da arte, a experiência estética por antonomásia. Se nesta trata-se de recriar em si o processo expressivo do artista, na natureza não haveria gesto produtivo a recriar:

A natureza de que nos falam as ciências naturais não é atividade no sentido rigoroso do termo, se por atividade da natureza devemos entender uma atividade não espiritual. (...) [A] natureza é, para o Croce da Estética, o meramente passivo, inerte, mecânico, material. E toda atribuição de atividade à natureza assim entendida outra coisa não é, para Croce, que uma via impropriamente antropomórfica, adequada sem dúvida às fábulas, mas não à filosofia. ${ }^{75}$

Perante a experiência usual do belo natural, Croce julgava que esta se tratava, muitas vezes, de uma mera confusão, havendo ali na verdade apenas uma má interpretação de juízos práticos sobre o agradável ou prazeroso. Não obstante, aceitava a possibilidade de experiências genuinamente estéticas. Nestes casos, porém, seus pretensos objetos mais não eram que convites à recriação de uma intuição dada:

A beleza natural é simplesmente um estímulo para a reprodução estética, o que pressupõe uma produção prévia. Sem precedentes intuições estéticas da imaginação, a natureza não pode provocar absolutamente nenhuma. No que toca à beleza natural, o homem é como o mítico Narciso junto à fonte. ${ }^{76}$

A natureza aqui aparece como materialidade à qual somente o espírito pode conferir significado, donde a concepção, por exemplo, do caráter histórico - e não natural - da paisagem e das belas vistas, na medida em que são sempre consideradas sob as lentes de uma dada sensibilidade cultural. Em última análise, a experiência do belo natural como intuição termina por se identificar à criação

\footnotetext{
${ }^{74}$ Cf. CROCE, B., Breviário de Estética; Aesthetica in nuce, pp. 146-147.

${ }^{75}$ RUSSO, R. La natura come forma elementare dello spirito: Benedetto Croce e il diritto al paesaggio, p. 5 (grifo do autor).

${ }^{76}$ CROCE, B. Estetica come scienza dell'espressione e linguística generale, pp. 116-117.
} 
artística, a qual tem, no entanto, a vantagem de fornecer, nos produtos físicos dela oriundos, bases muito mais coesas e eficazes para a reprodução estética. ${ }^{77}$

Croce rejeita também, coerentemente, a perspectiva da arte como imitação da natureza. Tendo em vista a dimensão "representacional" da arte, alega que esta não imita nem idealiza a natureza, opiniões que a seu ver falseiam a ordem própria da gênese da arte. O artista, afirma, não parte da realidade dada para aproximá-la a um ideal ou copiá-la mas, antes, "procede da impressão da natureza externa à expressão, quer dizer, ao seu ideal, e deste passa para o fato natural, o qual reduz a instrumento da reprodução do fato ideal". ${ }^{78}$ Neste sentido poder-se-ia dizer que é a natureza que obedece ao artista.

Findo este exame da filosofia geral de Pareyson, de sua concepção da estética e da estética de Croce, tem-se os subsídios mínimos necessários para que se adentre o território mesmo da pesquisa aqui proposta, a partir de um exame da estética da formatividade.

\footnotetext{
${ }^{77}$ Cf. RUSSO, R. La natura come forma elementare dello spirito, pp. $2 ; 4$.
}

${ }^{78}$ CROCE, B. Estetica come scienza dell'espressione e linguística generale, pp. 127. 


\section{2 \\ Formatividade e natureza}

\section{1.}

\section{Arte e formatividade}

A estética de Luigi Pareyson não pode ser compreendida, segundo afirma Finamore, somente como uma fenomenologia da arte, pois nasce do interior de seu existencialismo de cariz personalista e se ancora aos compromissos ontológicos do mesmo. Assim, seu conceito fundamental, o de formatividade, marcará não somente a filosofia da arte pareysoniana, mas igualmente sua filosofia da pessoa. ${ }^{79}$ Aprofundando tais liames, assinale-se, com Ciglia, que o esforço de Pareyson em campo estético se propõe

individuar e delimitar exatamente o lugar específico da arte no interior do âmbito mais vasto da experiência humana, considerada em toda a sua extensão. Mas esta individuação e esta delimitação não são certamente possíveis sem uma prévia interpretação filosófica compreensiva do inteiro universo da experiência humana que serve de fundo à experiência artística, e sem uma consequente focalização, seja da conexão orgânica e originária que subsiste entre experiência artística e experiência humana em geral, seja da diferenciação específica que se vem a instaurar entre uma e outra. ${ }^{80}$

Trata-se aqui, com efeito, de uma fundamentação existencial da arte, ou seja, de um esforço de compreensão da possibilidade do fenômeno artístico em suas várias modalidades, tendo a pessoa como ponto de partida. Nesse sentido, Pareyson esclarece que, por sua adesão à experiência, sua estética, embora se dedique a fornecer uma concepção geral da arte, não é "uma metafísica da arte, mas uma análise da experiência estética: não uma definição da arte considerada abstratamente em si mesma, mas um estudo do homem enquanto autor da arte e no ato de fazer arte". ${ }^{81}$

\footnotetext{
${ }^{79}$ Cf. FINAMORE, R. Arte e formatività, p. 13.

${ }^{80}$ CIGLIA, F. P. Ermeneutica e libertà, p. 122 (grifos do autor).

${ }^{81}$ PAREYSON, L. Estética: teoria da formatividade, p. 11 (grifos do autor). É, pois, à luz desta ênfase existencial que se deve interpretar a tentativa pareysoniana de uma definição geral da arte. Posto abarque em certa medida compromissos "essencialistas", não se deve confundi-la, como
} 
O conceito de formatividade, como afirmado acima, é o fundamento da estética pareysoniana. Ao valer-se do termo para batizar sua teoria (a despeito da pouca elegância que o próprio autor reconhecia no mesmo) em detrimento do usual termo forma, respondia o pensador a uma dupla exigência. Por um lado, embora mantendo a referência à forma, evitar as possíveis ambiguidades advindas do uso do termo, dentre os mais semanticamente carregados no contexto dos discursos sobre a arte. Mas também - e principalmente - por se explicitar no termo formatividade o caráter eminentemente dinâmico e ativo que singulariza a visão pareysoniana sobre a arte. A sua será antes uma estética da formatividade (como atividade produtora de formas) do que da forma - se esta for entendida como estaticidade inerte, isolada de sua gênese e de sua vida. Com efeito, o pensador afirmará que tanto a forma como o contato efetivo com a mesma somente serão possíveis se esta for compreendida em seu dinamismo, como resultado ou culminação de um processo. ${ }^{82}$

Assim, no conceito de formatividade se manifesta aquele sentido fundamental de atividade, de um fazer, no qual o autor buscará o caráter próprio da arte, em oposição às inúmeras concepções filosóficas que a consideravam, antes, sob a égide quer do conhecer, quer do exprimir. Nestas três abordagens, aliás, Pareyson reconhecia os modos tradicionais segundo os quais a arte veio a ser compreendida historicamente, e aos quais, a despeito de suas matizações e acentos particulares, as diferentes concepções filosóficas sobre ela se podiam

afirma o próprio filósofo, com o esforço de esgotar a arte numa eventual conceituação totalizante e definitiva. Tem-se em vista, antes, "um conceito por assim dizer operativo: um conceito que longe de pretender encerrar e esgotar de uma vez por todas a essência da arte, servisse como princípio regulador e orientador na experiência artística" (ibid., p. 11, grifos do autor). Deste modo, apesar de muito abrangente (com aparente negligência da multiplicidade dos objetos artísticos, dos gêneros e dos conceitos de arte em suas existências e aplicações históricas concretas), pode-se defender a solução pareysoniana como uma definição relativamente aberta e consciente de seu caráter problemático, limitado e historicamente condicionado. A teoria em questão não busca mais que um "mínimo denominador comum" para se pensar a arte; e, por isso, naturalmente "generaliza, por comodidade de discurso comum, uma série de fenômenos concretos que possuem uma vivacidade de determinações que na definição se perdem necessariamente" (ECO, U., A definição da arte, p. 143).

${ }^{82}$ Cf. PAREYSON, L., Estética: teoria da formatividade, p. 9. 
enfim reduzir. ${ }^{83}$ Nessa ênfase no fazer já se anuncia, também, uma primeira divergência de base em relação à estética crociana, notoriamente marcada, por um lado, pela íntima associação e relevo das dimensões cognitiva e expressiva e, por outro, pela considerável negligência em relação a tudo quanto remetesse ao efetivo processo de produção da obra de arte. ${ }^{84}$

\subsection{1.}

\section{A formatividade}

Pareyson entende por formatividade a atividade que consiste em um "'fazer' que, enquanto faz, vai inventando o modo de fazer". ${ }^{85}$ Dessa definição depreende-se o caráter organizador, executivo, ordenador e construtivo da formatividade, seu cunho de esforço dirigido a um resultado, mas também - e simultaneamente - o seu aspecto de busca e incerteza (sendo invenção). O formar implica um fazer que não se resume à realização de um projeto preestabelecido, cujos passos, etapas e procedimentos fossem todos prescritos rigorosamente de antemão, e os quais bastaria então executar, mas antes exige a constante invenção/descoberta dos modos segundo os quais pode vir a ser bem-sucedido.

${ }^{83}$ Cf. PAREYSON, L., Os problemas da estética, pp. 21-22. Conforme esclarece um comentador: "De modo sucinto, pode-se dizer que no mundo arcaico a techné estava associada à habilidade de fazer, a um certo desenvolvimento, e ela era pois vista segundo o prisma da atividade produtiva utilizada em sua construção. No horizonte clássico, ela é vista essencialmente como mimesis, como imitação ou cópia, como representação de uma realidade anterior e exterior à obra ela mesma, achando-se assim associada a uma forma de conhecimento. E, desde o Romantismo, ela é vista como expressão de uma subjetividade, como uma forma de manifestação que será basicamente colorida pelos afetos, pela dimensão emocional da condição humana" (VALVERDE, M. Les limites du jeux poétique, p. 49). Enfatize-se, para além das necessárias esquematizações, que não se trata de afirmar um dos elementos enquanto concomitantemente se nega os demais, mas de reconhecer a maior prevalência de uma ou outra dessas dimensões segundo tais ou quais pensadores ou épocas históricas. É nesse sentido que Pareyson afirma, por exemplo, a predominância, na Antiguidade, da concepção da arte como um fazer e, no período romântico, como um exprimir. São muito variados os modos segundo os quais estas concepções se combinaram historicamente. E o próprio Pareyson, com efeito, ressaltará as valências expressiva e cognitiva da arte entendida como um fazer.

${ }^{84}$ Cf. D'ANGELO, P. Estetica, p. 64; Idem, L'opera d'arte come ricerca e come riuscita: la considerazione dinamica del processo artistico in tre estetiche post-crociane, p. 52;

${ }^{85}$ PAREYSON, L., Estética: teoria da formatividade, p. 20. 
Intimamente relacionado à formatividade está o caráter de êxito, que constitui o seu critério. Ao tratar deste outro conceito fundamental de sua estética, Pareyson explica que "o êxito é tal que somente quando completamente realizado mostra claramente a própria lei”, ${ }^{86}$ ou seja, é um resultado que só se pode mostrar ex post facto como aquele que se intencionava, e que, enquanto se busca, é adivinhado antes que conhecido. Uma operação é formativa, pois, quando tem em vista tal resultado, quando "da obra resultante se pode afirmar que está bem feita não enquanto 'obedeceu às regras' mas enquanto é um 'sucesso', um 'êxito', ou seja, quando descobriu as próprias regras ao invés de aplicar regras prefixadas". ${ }^{87}$

Não se pode, pois, adentrar o sentido do formar senão a partir da relação que se institui entre o fazer e o tentar. Um fazer que invente o modo de fazer exige que se proceda através de tentativas: “o formar, portanto, é essencialmente um tentar, porque consiste em uma inventividade capaz de figurar múltiplas possibilidades e ao mesmo tempo encontrar entre elas a melhor, a que é exigida pela própria operação para o bom sucesso". ${ }^{88}$

Esse nexo formativo entre fazer e tentar, longe de se encontrar somente na arte, é próprio a toda a vida espiritual. Em todos os âmbitos o homem deve atuar descobrindo, inventando, tentando. Assim, antes que se estabeleça a formatividade como fundamento da arte, é preciso reconhecer a dimensão formativa já presente em toda a experiência humana. A formatividade possui uma abrangência que não só ultrapassa o domínio da arte stricto sensu, mas em última instância o possibilita.

\subsubsection{1.}

\section{Atividades e operações}

Como visto, a formatividade se institui como uma atividade entre as demais. No entanto, recorda o autor que "as atividades humanas não podem ser exercidas a não ser concretizando-se em operações, i. é, em movimentos destinados a culminar em obras". ${ }^{89}$ Ou seja, é propriamente por meio de operações que as

\footnotetext{
${ }^{86}$ PAREYSON, L., Estética: teoria da formatividade, p. 60.

${ }^{87}$ PAREYSON, L., Estética: teoria da formatividade, p. 59-60.

${ }^{88}$ PAREYSON, L., Estética: teoria da formatividade, p. 61

${ }^{89}$ PAREYSON, L., Estética: teoria da formatividade, p. 20.
} 
atividades, quer sejam intelectuais, morais, artísticas, se podem efetivamente realizar.

A operosidade própria da pessoa ocupa papel de destaque na fundamentação da estética de Pareyson. A compreensão do inteiro âmbito da experiência humana vem marcada, no contexto teorético em que o autor formulou a teoria da formatividade, pela ênfase posta sobre o caráter positivo de dita experiência - ou seja, nos aspectos produtivos, construtivos e inventivos da pessoa. Não obstante, é importante salientar que esta operosidade não é jamais absoluta, pois que a pessoa se inscreve sempre no interior de uma situação já dada previamente, com a qual se deve confrontar, e a qual lhe impõe uma margem à atuação. ${ }^{90}$ Os dados da situação são oferecidos inapelavelmente à pessoa e dela independentes, devendo esta operar sobre aqueles, os quais se personalizam exatamente na medida em que não se podem separar da iniciativa que lhes responde. ${ }^{91}$ Tem-se aqui o nexo incindível de atividade-receptividade, que, sob vários aspectos e em vários níveis, comparece nas teorizações pareysonianas sobre a pessoa e a arte. Assim,

no operar humano não há receptividade sem atividade. Pressupõe, na verdade, uma ocasião, um estímulo: toda iniciativa é sempre iniciada, sugerida, posta em movimento; mas isto só acontece no interior do arco de um processo ativo que permite e garante o acolhimento da sugestão, pois de outro modo o estímulo e a sugestão não seriam tais nem deles haveria recepção. Daí deriva a necessidade de afirmar como receptividade somente aquela que se atualiza através da atividade e nesta se prolonga. ${ }^{92}$

Considerando-se este caráter de iniciativa iniciada inerente à pessoa, entende-se também que as noções de criatividade e criação só podem ser aplicadas à formatividade - mesmo quando essas assumem, na arte, seu papel mais inovador - apenas impropriamente, em razão de seu caráter relativo. ${ }^{93}$

\footnotetext{
${ }^{90}$ Cf. CIGLIA, F. P., Ermeneutica e libertà, p. 127. O mesmo Ciglia salienta que os aspectos mais propriamente negativos desta experiência, conquanto jamais de todo ausentes da reflexão de Pareyson, virão a ser aprofundados e trazidos ao primeiro plano apenas na última fase de seu pensamento.

${ }^{91}$ Cf. PAREYSON, L. Esistenza e persona, p. 197.

${ }^{92}$ MURA, A. La concezione estetica in Luigi Pareyson, p. 28.

${ }^{93}$ Cf. PAREYSON, L., Conversaciones de estética, p. 36. D’Angelo aproxima o conceito de formatividade à noção corrente de criatividade, e atribui ao professo cristianismo de Pareyson sua
} 


\subsubsection{2.}

\section{Leis e regras}

A formatividade se inscreve no interior de uma dinâmica tensional. Como esclarece Pareyson, toda operação tem suas regras e fins, e os procedimentos adotados para cumpri-los se lhes devem adequar, dado que o critério para aferição do sucesso é o alcance do fim pela conformidade às leis. ${ }^{94} \mathrm{O}$ agir orientado por uma finalidade supõe o alcance desta, como coroamento do processo, aquilo que permite dizê-lo bem-sucedido. Não obstante, essas lei e finalidade não diluem a operação numa total determinação heterônoma, a exigir apenas uma resposta mecânica e prefixada, pois o resultado da operação, como obra, será individual, singular como a pessoa que aí opera. ${ }^{95}$

Estabelece-se, pois, uma tensão entre a necessidade de uma resposta singular e pessoal a um reclamo de ordem genérico: "entre a generalidade da finalidade a alcançar e da legalidade a respeitar, todavia, e a pontual individualidade da obra a realizar, existe (...) sempre um hiato considerável, que a operação formativa é chamada a preencher". ${ }^{96}$ Isto porque só por meio da formatividade, deste fazer inventivo, que se move por tentativas, se pode alcançar a regra individual que resulta no êxito da operação, ou seja, o modo particular segundo o qual se deve operar visando ao sucesso. Como sintetiza o autor, "é mister que no curso da operação essa legalidade ou essa finalidade se tornem regra individual da obra a fazer, o que sem dúvida exige um ato de invenção". ${ }^{97}$ Tem-se aqui uma estreita relação entre lei (geral) e regra (individual), as quais são mediadas pelo esforço formativo.

recusa do uso deste segundo termo. Mas se este é o caso, tal se dá exatamente para melhor distinguir entre uma produtividade que se poderia tomar como absoluta e aquela da pessoa, sempre condicionada. (ver D'ANGELO, P. Il ruolo di Luigi Pareyson nell'estetica italiana del Novecento, p. 63). Ressalte-se também que Pareyson se vale por vezes do termo criatividade e seus correlatos em seus escritos de estética, mas em contextos que permitem entendê-lo em seu caráter "pessoal", logo limitado e relativo.

${ }^{94}$ Cf. PAREYSON, L., Estética: teoria da formatividade, p. 62.

${ }^{95}$ Cf. PAREYSON, L., Estética: teoria da formatividade, p. 60.

${ }^{96}$ CIGLIA, F. P., Ermeneutica e libertà, p. 128.

${ }^{97}$ PAREYSON, L., Estética: teoria da formatividade, p. 63 
Uma operação admite assim um duplo caráter. Como se exige um esforço formativo para que se invente o modo de levá-la a cabo e atingir seus fins, ela se constitui, por um lado, como adequação ao fim determinado e submissão a suas leis; por outro, como dotada de uma regra individual, a qual a faz um êxito. Toda operação admite então uma dimensão "estético-formativa" (enquanto é um êxito inventivo) e uma dimensão própria à sua adequação a um fim e a uma legalidade de ordem geral. Porém, "nem leis separadas das regras, nem regras separadas das leis podem conduzir ao êxito; este reclama leis e fins, mas estes não agem antes que seja encontrada a regra". 98

Com base no exposto, pode-se compreender que não somente aquelas operações que redundam na produção de objetos concretos e exteriores ao homem (nas quais o elemento produtivo é flagrante), mas também seus próprios atos e sua vida interior são atravessados pela dimensão formativa, pois também ali se institui a necessidade de mediação entre lei geral e regra particular. Nessa perspectiva teórica, mesmo os aspectos aparentemente mais contemplativos da experiência humana passam a ser abordados e compreendidos processualmente, como resultado ou conclusão de operações eivadas de formatividade. ${ }^{99}$

\subsection{2. \\ O conceito de forma}

Uma vez discutido o caráter da formatividade no seu aspecto de atividade, deve-se passar à consideração do seu outro elemento constitutivo, a noção de forma. Pareyson ressalta que as atividades se concretizam em operações destinadas a resultar em obras, mas que, por outro lado, "só fazendo-se forma a obra chega a ser tal (...). Nenhuma atividade é operar se não for também formar, e não há obra acabada que não seja forma". ${ }^{100}$

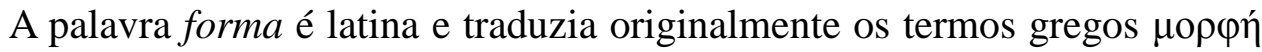

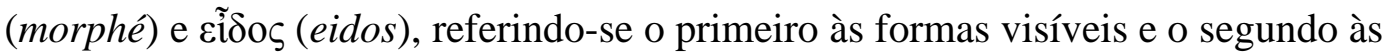
conceptuais, ideais, acenando já à polissemia que o constituiria ulteriormente.

\footnotetext{
${ }^{98}$ FINAMORE, R. Arte e formatività, p. 39.

${ }^{99}$ Cf. CIGLIA, F. P., Ermeneutica e libertà, p. 127.

${ }^{100}$ PAREYSON, L. Estética: teoria da formatividade, p. 20.
} 
Historicamente o termo adquiriu diversos significados, que se identificam especialmente quando consideramos os termos que em cada caso lhe são contrapostos. Assim, forma pode se opor a conteúdo, elemento, matéria, assumindo acepções peculiares. ${ }^{101} \mathrm{Um}$ dos intentos teóricos de Pareyson é de evitar as contraposições usuais entre forma e conteúdo e entre forma e matéria. Rejeitará, assim, as disjunções extremas que em âmbito geral se manifestam entre materialismo e espiritualismo, ao propor uma concepção de forma que congrega os aspectos espirituais e materiais da realidade. ${ }^{102}$ Do mesmo modo, rejeitará a disjunção, atuante em âmbito propriamente estético, entre propostas conteudistas e formalistas no tratamento da arte.

O termo forma admite, segundo Tatarkiewicz, cinco sentidos relevantes para o domínio estético. A forma pode ser compreendida como disposição das partes de um todo, isto é, o arranjo segundo o qual estas se organizam (a noção aqui é entendida abstratamente, pois se refere apenas a uma disposição de partes e não à coisa que apresenta tal disposição). Outra acepção (e aqui a forma é contraposta ao conteúdo) é a daquilo que se dá aos sentidos, enquanto modo de apresentação, admitido já aí o aspecto material - uma forma que organiza e apresenta de certa maneira um conteúdo. Um terceiro sentido se obtém por uma restrição do precedente, e forma passa a referir unicamente o limite ou contorno de um dado objeto e não a totalidade de seus aspectos presentativos, isto é, apenas a figura exterior. $\mathrm{O}$ quarto sentido é uma ancestral contribuição aristotélica: a forma é entendida como a essência conceptual de um objeto, seu princípio organizador intrínseco, em oposição a seus acidentes. Por fim, uma ulterior acepção é proposta por Kant, que entende a forma como o aporte do entendimento àquilo que se percebe (os dados brutos da experiência). ${ }^{103}$

\footnotetext{
${ }^{101}$ Cf. TATARKIEWICZ, W. História de seis ideas, p. 253.

${ }^{102}$ Cf. BLANCO SARTO, P. Hacer arte, interpretar el arte, p. 302.

${ }^{103}$ Cf. TATARKIEWICZ, W. História de seis ideas, pp. 254-255.
} 


\subsubsection{1.}

\section{A forma como organismo, resultado e modelo}

O exame da concepção pareysoniana da forma a contextualiza em relação a esses sentidos vigentes. Pareyson esclarece o sentido em que se a deve conceber ao afirmar que

aqui se compreende a forma como organismo, que goza de vida própria e tem sua própria legalidade intrínseca: totalidade irrepetível em sua singularidade, independente em sua autonomia, exemplar em seu valor, fechada e aberta ao mesmo tempo, finita e ao mesmo tempo encerrando um infinito, perfeita na harmonia e unidade de sua lei de coerência, inteira na adequação recíproca entre as partes e o todo. Em segundo lugar (...) o caráter dinâmico da forma a qual é essencial o ser um resultado, ou melhor a resultante de um "processo" de formação, pois a forma não pode ser vista como tal se não se vê no ato de concluir e ao mesmo tempo incluir o movimento de produção que lhe dá nascimento e aí encontra o próprio sucesso. ${ }^{104}$

Esta descrição arrola uma série de traços característicos da forma, que contribuem a perfazer seu perfil. Três são suas determinações fundamentais: a forma é um êxito, é um modelo exemplar e é um organismo. Ressalte-se de início a consideração desta como um êxito: este é tal por ser um resultado de um processo fundado em tentativas. Toda forma é resultante de um processo de formação, e só se a pode compreender se ela é considerada enquanto uma conclusão ou um acabamento que contém e abrange todos os momentos formativos que a configuraram como tal. ${ }^{105}$ Paralelamente, a consideração como resultado implica o reconhecimento de um risco, o de que a obra não saísse a contento, falhasse. A forma se impõe como êxito não só porque é, mas igualmente porque se reconhece que poderia não ter sido, sendo todo tentar passível de malogro. É esta condição

\footnotetext{
${ }^{104}$ PAREYSON, L. Estética: teoria da formatividade, pp. 9-10.

${ }^{105}$ Ressalte-se que captar a forma como resultado não implica uma consideração "genética" da mesma. Diferentemente de uma abordagem genética, empenhada em reconstruir documentalmente as etapas do processo de formação e seus antecedentes, uma consideração dinâmica se volta para a forma já conclusa, na qual recupera o processo enquanto incluído na própria forma. Aceder ao caráter de resultado não se confunde, pois, com apreender e reconstruir uma ordem "temporal", seja em termos históricos ou mesmo psicológicos (cf. D'ANGELO, P., L'opera d'arte come ricerca e come riuscita, pp. 63-64).
} 
de algo que parece escapar à contingência que lhe permite demandar atenção e reconhecimento. ${ }^{106}$

A forma é igualmente passível de interpretação e contemplação, e, por isso, a despeito de fechada em seu caráter de conclusão, é igualmente aberta em seu oferecer-se ao esforço de penetração, donde se poder ver como simultaneamente finita e infinita. Daí decorre, por sua vez, seu caráter exemplar, modelar, o qual pode suscitar emulações visando a novas formas. ${ }^{107}$ Diante de análogas circunstâncias ou problemas, uma solução que se mostrou bem-sucedida se torna sugestão de um novo, embora semelhante, desenvolvimento. É próprio da "vida" da forma este convidar a ulteriores prolongamentos que a tomem por paradigma. $^{108}$

Estas características se congregam e unificam, no entanto, na consideração da forma como organismo, tomada de empréstimo a Aristóteles. O estagirita formulou a noção de organismo - e cunhou o termo pata designá-lo - referindo-o à natureza, não à arte. Não obstante, no entender de Pareyson, a adequada compreensão da dimensão artística revela sua particular pertinência também nesse âmbito. ${ }^{109}$ Um organismo, segundo Aristóteles, tem por seu traço essencial o ter o seu fim em si mesmo - em oposição à matéria inorgânica que tem seu fim exteriormente a si. Por esta razão, sua operação deve ser a atualização de suas potencialidades inerentes, um manifestar-se, uma explicitação do que nele é implícito, tal como no desenvolvimento gradual de todos os seres orgânicos, nos quais o crescimento não é, como na matéria inerte, mera adição de elementos heterogêneos, mas um desdobramento coeso e orientado de modo finalístico. ${ }^{110}$

Ao afirmar a organicidade da forma, Pareyson salienta que esta tem uma "vida" própria, com o que tem em vista a sua independência quer em relação ao seu autor, quer em relação a circunstâncias externas. É totalmente adequada a si mesma e encontrou na conclusão de seu processo de produção seu verdadeiro cumprimento. Preside-a uma lei "orgânica” que garante sua coerência interna, de

\footnotetext{
${ }^{106}$ Cf. PAREYSON, L., Problemi dell'estetica I. Teoria, p. 126.

${ }^{107}$ Cf. BLANCO SARTO, P. Hacer arte, interpretar el arte, p. 62.

${ }^{108}$ Cf. PAREYSON, L., Problemi dell'estetica I. Teoria, p. 127.

${ }^{109}$ Cf. PAREYSON, L., Conversaciones de estética, p. 85.

${ }^{110}$ Cf. STACE, W. T. A critical history of greek philosophy, pp. 324-326; ARISTÓTELES, Partes dos animais I, V, 644b-645b.
} 
modo que mais que uma relação parte/todo, nela se manifesta um caráter de unitotalidade. Este caráter de unitotalidade compreensiva e autônoma permite que se aplique à forma, em sentido obviamente analógico, figurado, noções biológicas como as de vida e organismo. ${ }^{111}$ Igualmente essencial a esta consideração é a ideia do desenvolvimento peculiar à forma, a ser abordado posteriormente.

Em confronto com os supracitados sentidos históricos de que o termo forma se revestiu, compreende-se que a forma pareysoniana não pode ser identificada com aqueles que referem apenas aspectos puramente exteriores, como a disposição material das partes, ou que a reduzem à figura exterior e sensória, já que combina os aspectos físico e espiritual. Também se distancia de uma concepção metafísica hilemórfica, que a contrapõe à matéria, visto que nela se afirma a forma como o organismo em sua totalidade e não apenas um de seus princípios estruturantes. Igualmente, recusam-se in limine compreensões aparentadas à kantiana, dada a idealidade que a caracteriza. ${ }^{112}$ Blanco Sarto aproxima a forma pareysoniana, dentre as listadas por Tatarkiewicz, à concepção de forma como estrutura, mas com bastantes ressalvas, pois ao caráter abstrato e mecânico que esta revela como "disposição das partes", se deve contrapor a forma como organismo vivente. Mais ainda, poder-se-ia dizer que, mais que a disposição das partes, tomada em si mesma, Pareyson entende a forma, concretamente, como a coisa mesma que apresenta tal disposição: “a forma é todo o organismo, e não só uma parte ou um de seus co-princípios. A forma é todo o ente, o que implica que esta seja toda a "matéria formada". ${ }^{113}$

\footnotetext{
${ }^{111}$ Cf. PAREYSON, L., Problemi dell'estetica I. Teoria, p. 126; BLANCO SARTO, P. Hacer arte, interpretar el arte, p. 61.

${ }^{112}$ Ao tratar da concepção kantiana de forma, Tatarkiewicz tem em vista, antes de tudo, a ideia desta como estrutura a priori, como condição de possibilidade da cognição humana. No contexto da estética kantiana, a questão da forma sem dúvida adquire mais relevância para o pensamento de Pareyson, enquanto põe em cena os problemas da finalidade (objetiva e subjetiva), perfeição etc. No entanto, ainda aí é oportuno distinguir que, em Kant, permanece uma oposição da forma a alguma "matéria" (como quer que se a conceba), numa relação de tipo determinante-determinável (ver, por exemplo, KALAR, B., The demands of taste in Kant's aesthetics, pp. 67-71) enquanto matéria e conteúdo são, na visão de Pareyson, constituintes da forma que, longe de designar algum tipo de determinação, designa a coisa enquanto determinada.

${ }^{113}$ BLANCO SARTO, P. Hacer arte, interpretar el arte, p. 64.
} 


\title{
2.1.2.2.
}

\section{Vida como produção de formas}

Como correlato da formatividade, as formas se espraiam igualmente por todo o campo da experiência. Ao admitir sempre o concurso da formatividade, a pessoa é produtora de formas todo o tempo. Como salienta Eco:

Toda a vida humana é, para Pareyson, invenção, produção de formas; toda a atividade humana, tanto, no campo moral como no do pensamento e da arte, origina formas, criações orgânicas e perfeitas, dotadas de compreensibilidade e autonomia próprias: são formas produzidas pela ação humana os edifícios teoréticos ou as instituições civis, as realizações quotidianas ou os empreendimentos técnicos, um quadro e uma poesia. ${ }^{114^{3}}$

Mesmo a pessoa, enfim, se pode assimilar a esta compreensão da forma, pois nela se encontram os aspectos de totalidade e de desenvolvimento. À sua totalidade, em cada momento conclusa em si, se associa o caráter definido, limitado e circunscrito da forma. Ao mesmo tempo, a pessoa é um esforço de autoconstrução e afirmação. Tomada num qualquer de seus momentos, a pessoa é forma, como totalidade fechada; em seu devir, é incessante operar, e como tal, artífice de novas formas - da própria forma que é e das que produz para além de si. Da realidade desta forma que suscita formas Pareyson conclui que

\begin{abstract}
tudo é forma, forma viva, e definida, com um centro que, por lei de coerência, mantém unidas as partes, com vida própria e autônoma (...). se uma filosofia do homem é sempre uma filosofia da pessoa (...) é necessário concluir que não há filosofia da pessoa que não seja ao mesmo tempo uma filosofia das formas. A mobilidade indefinida e a histórica desenvolvibilidade do homem não passam de plasticidade, que tende a plasmar-se em formas e a plasmar formas. ${ }^{115}$
\end{abstract}

Sendo a pessoa também forma num mundo de formas oriundas de um empenho pessoal, instaura-se um nexo entre filosofia da pessoa e filosofia da forma, a partir do qual também a forma, por sua origem, tem a independência e singularidade próprias ao caráter de personalidade, de sorte que "a inspiração personalista (...) se faz mais intensa e assume quase o caráter da unanimidade. Tudo é personalizado e tudo se eleva a uma sacralidade axiológica. Tudo é forma

\footnotetext{
${ }^{114}$ ECO, U. A definição da arte, p. 15.

${ }^{115}$ PAREYSON, L. Estética: teoria da formatividade, p. 177.
} 
e a forma tem uma dignidade pessoal porque é sempre em algum modo pessoa". 116

\subsection{3.}

\section{Formatividade e especificação}

Segundo Pareyson, não somente a formatividade comparece em toda a vida espiritual, mas nesta se manifesta uma imbricação mútua de todas as atividades, em razão da unitotalidade própria à pessoa. Nesse sentido, quer se trate de uma demonstração matemática, de um agir moral pessoal, da fabricação de utensílios, ou de obras esteticamente orientadas, e quer os resultados dessas operações se exteriorizem fisicamente ou não, a pessoa sempre comparece em sua completude, pois "as atividades humanas não só não são isoladas entre si, mas, cada uma, para que seja ela própria, tem necessidade de todas as outras". ${ }^{117}$

Mas, se todas as atividades estão igualmente dadas em toda operação, a simples distinção cotidiana entre os diferentes âmbitos de operação passa a exigir, uma explicação. Pareyson esclarece que

Toda operação humana é sempre ou especulativa ou prática $o u$ formativa mas, seja qual for a sua especificação, é sempre ao mesmo tempo tanto pensamento, como moralidade $e$ formatividade. Uma operação não se determina a não ser especificando uma atividade entre as outras, mas não pode fazê-lo a não ser concentrando em si todas as outras simultaneamente. Em toda operação existe, ao mesmo tempo, especificação de uma atividade e concentração de todas as atividades: esta é a estrutura do operar. ${ }^{118}$

É, por sua vez, exatamente sobre as noções de especificação e concentração das atividades que repousa a possibilidade, por um lado, da eclosão da arte como fenômeno autônomo no mundo humano e, por outro, da participação do elemento artístico em todas as esferas deste mesmo mundo. Constate-se de início o que se compreende por especificação:

A especificação consiste no acentuar uma atividade a ponto de torná-la predominante sobre as outras e intencional em uma operação. As atividades remanescentes se subordinam àquela que desse modo se especificou e conspiram

\footnotetext{
${ }^{116}$ MURA, A. La concezione estetica in Luigi Pareyson, p. 31.

${ }^{117}$ FINAMORE, R. Arte e formatività, p. 42.

${ }^{118}$ PAREYSON, L., Estética: teoria da formatividade, p. 24 (grifos do autor).
} 
em sua intenção (...). Nenhuma das atividades humanas consegue especificar-se em uma operação sem a conspiração, a contribuição, o apoio e o controle de todas as outras, cada uma das quais, no mesmo ato de subordinar-se a ela, continua todavia agindo em seu caráter próprio. ${ }^{119}$

Esta distinção esclarece a possibilidade, por um lado, de sempre se reencontrar a formatividade em todos os afazeres humanos, independentemente das atividades que em cada caso se especifiquem e, por outro, de afirmar também a operação na qual é a própria formatividade a se especificar, concentrando as demais. Nessa especificação Pareyson encontra o caráter próprio da arte, a qual será formatividade específica e intencional. Tem-se assim fundada uma "artisticidade" difusa na vida e uma efetiva artisticidade própria à arte. Os dois campos se veem como distintos e ao mesmo tempo indissoluvelmente unidos. ${ }^{120}$

A artisticidade relativa que perpassa toda a vida humana se manifesta pelo esforço, em qualquer âmbito, de fazer o que quer que seja de modo exitoso, adequado. Conforme esclarece Pareyson: "isso explica como pode haver arte em toda atividade humana, ou melhor, como há a arte de toda atividade humana, no sentido de que, em qualquer circunstância, trata-se de fazer com arte". ${ }^{121}$ Tem-se aqui, portanto, uma gradual passagem desde as manifestações mais modestas e inconspícuas da formatividade até a culminação que esta encontra na arte. O modo próprio de considerar a experiência artística é contra o fundo de empenhos formativos que a prepara e possibilita. Pareyson dá grande ênfase à solidariedade existente entre estes campos, asseverando que não há saltos, soluções de continuidade, mas antes matizações entre a difusa artisticidade da experiência e aquela da arte. $^{122}$

É possível conceber, assim ocasionais indistinções e hibridismos, como a possibilidade aventada pelo pensador de, em dados contextos, certas realizações

\footnotetext{
${ }^{119}$ PAREYSON, L., Estética: teoria da formatividade, p. 24.

${ }^{120}$ Neste sentido, Pareyson propõe uma distinção entre o estético (como pertinente a toda a vida espiritual) e o artístico (como atribuição própria da arte em sua especificação). Esta distinção, conquanto fluida, é importante enquanto afirma um princípio de diferenciação entre as duas experiências, diferenciação que era negada pela estética crociana (Cf. PAREYSON, L., Problemi dell'estetica I. Teoria, p. 123).

${ }^{121}$ PAREYSON, L., Os problemas da estética, p.31 (grifos do autor).

${ }^{122}$ Cf. PAREYSON, L., Os problemas da estética, pp. 33-34.
} 
culturais só concretizarem seu fim particular quando igualmente constituem um êxito plenamente artístico, ou vice-versa - realizações nas quais a mútua interpenetração de seus valores concorrentes, ali de todo unificados, impede que delas se faça uma consideração unilateral, quer do ponto de vista de seu êxito formativo, quer de seus eventuais fins declarados ou implícitos. ${ }^{123}$

\subsubsection{1. \\ Dimensão artística da experiência em geral}

A estética de Pareyson, conquanto ainda enfatizando a culminação formativa que se encontra na arte (e a cuja detida análise, em suas características e potencialidades, devota a maior parte de seus esforços), deixa em aberto um vasto campo de possibilidades filosóficas, na medida em que convida a reconhecer o teor estético da experiência comum. No âmbito da vida intelectual, pode-se reconhecer, à luz dessa ideia, que a dinâmica própria à execução de atos de pensamento envolve o encadeamento de juízos, raciocínios, deduções, hipóteses, devendo a cada vez o modo próprio de realizar tais movimentos ser produzido e inventado segundo as eventuais necessidades em questão. Igualmente, a vida moral se pauta pela invenção do melhor modo de levar a cabo atos que satisfaçam os ditames em jogo e as circunstâncias específicas de cada caso. ${ }^{124}$

Do mesmo modo se deve considerar a penetração da dimensão estética e do pendor artístico que se fazem notórios nas mais variadas esferas, encampando a vida social e os costumes, o entretenimento, os processos industriais e as vidas civil, política e religiosa. ${ }^{125}$ Opera-se, igualmente, uma revalorização das "artes e ofícios" e consigo, dos demais misteres marcados pelo caráter técnico e de subsunção a um projeto, neles sobressaindo o elemento de empenho humano e de “criatividade" pessoal. ${ }^{126}$ E mais: conquanto este caráter de onipresente

\footnotetext{
${ }^{123}$ Cf. PAREYSON, L., Os problemas da estética, p. 37. É o que o autor parece ter em mente ao se referir, por exemplo, àquelas "civilizações de alto sentido artístico, como a grega e a humanística, onde em cada atividade se persegue, juntamente com o valor específico daquela atividade determinada, também o valor artístico, e não se consegue conceber nenhuma atividade que não tenha um êxito artístico" (Ibidem, p. 30).

${ }^{124}$ Cf. PAREYSON, L. Estética: teoria da formatividade, p. 25.

${ }^{125}$ Cf. PAREYSON, L., Os problemas da estética, p. 30.

${ }^{126}$ Cf. FINAMORE, R. Arte e formatività, p. 42.
} 
artisticidade fosse atestado ao longo de toda a história, Pareyson julgava que a sua época era particularmente propícia a salientá-lo. Profundas mudanças sociais e tecnológicas (o progresso da técnica, as comunicações de massa, o design industrial) impunham reconhecer, por exemplo, "certa presença da arte na funcionalidade de um protótipo mecanicamente repetível ao infinito". ${ }^{127}$

A consideração em tela repõe em jogo, por fim, a própria extensão e delimitação do conceito e do termo arte, acenando à sua amplitude semântica e a seus diferentes usos históricos. Assim, a renovada compreensão da arte recupera, em termos de formatividade geral,

aquelas que uma longa tradição sempre considerou "artes" e que são todas, na realidade, "poesias de certo modo reais", como as artes da guerra, do governo, da cirurgia, e as artes de demonstrar, convencer, persuadir, até às já lembradas artes de viver e pensar. ${ }^{128}$

Verifica-se no pensamento de Pareyson, indubitavelmente, uma aproximação entre arte e vida, calcada em uma concepção existencial unitária do atuar do homem, a qual contrasta com a ênfase crociana na distinção e na autonomia - mesmo que não absolutas - da arte em relação aos demais empreendimentos do homem. ${ }^{129}$

\subsubsection{2.}

\section{Arte como formatividade específica: realização e inovação}

Enquanto as demais operações não podem ser senão constitutivamente formativas, na arte a formatividade é intencionalmente formação, na qual a formatividade busca a forma por si mesma. Trata-se de um exercício de pura formatividade. ${ }^{130} \mathrm{~A}$

\footnotetext{
${ }^{127}$ PAREYSON, Conversaciones de estética, p. 13.

${ }^{128}$ PAREYSON, L. Estética: teoria da formatividade, p. 65.

${ }^{129}$ Em Croce, conquanto não se propusesse uma separação absoluta entre o domínio estético e as outras formas do espírito, a ênfase era posta antes na sua distinção, de modo a salvaguardar a autonomia da arte. Pareyson, sem rejeitar a autonomia, funda-a na noção de especificação, que permite uma maior integração entre os domínios pela afirmação de um princípio de unidade das atividades, juntamente ao de sua distinção, já salientado por Croce (cf. CANEVA, C. Bellezza e persona, pp. 57-58).

${ }^{130}$ PAREYSON, L., Estética: teoria da formatividade, pp. 25-26. Ressalte-se que a expressão "formatividade pura", repetidamente usada por Pareyson para se referir à arte, não supõe,
} 
especificação da formatividade implica, por seu turno, a recusa de quaisquer regras ou finalidades exteriores que possam constranger o formar, agora autônomo. O exercício da pura formatividade, ausente toda restrição externa ao ato formativo mesmo, só não recai na arbitrariedade se ele mesmo se constitui em lei de seu próprio exercício. Deste modo, a arte, como formatividade especificada, rejeita quaisquer critérios heterônomos sob cuja determinação se julgue seu sucesso.

Se nas demais operações, é sempre possível julgar os resultados também à luz do aspecto formativo - por este se conjugar inexoravelmente com o intento particular que se persegue em cada caso e que constitui seu efetivo critério de julgamento - na arte a resultante passa a ter em si o seu próprio e único critério. Da obra de arte não será requerido preencher um hiato entre lei geral e regra individual, mas "constituir inteiramente regra e lei, uma regra e uma lei que são, contemporaneamente, absolutamente individuais, embora dotadas de um valor universal". ${ }^{131}$ Daí que, se se tem em vista a inventividade inerente à experiência, a arte deva aparecer como invenção radical:

Nas outras operações, ao menos uma coisa não tem que ser inventada, e é a ratificação das possibilidades inventadas por parte de certas leis ou certos fins. $\mathrm{Na}$ arte quando se trata da obra, tudo tem que ser inventado e, sobretudo, aquilo que institui a sua regra como tal, i. é, a adequação da obra consigo mesma. ${ }^{132}$

$\grave{A}$ arte entendida como formatividade especificada corresponde, como seu produto, a forma que busca validade somente sob seu ser forma - o puro formar engendra a pura forma. A forma artística configura, pois, um incremento da realidade, na medida em que é nova, irrepetível, e, uma vez trazida à existência,

obviamente, a não-participação das esferas intelectual e moral em seu exercício, pelas mesmas razões aduzidas pouco acima. Nesse sentido, Eco recorda que "a filosofia idealista crociana, ao definir a arte como intuição do sentimento, afirmou claramente, por conseguinte, que ela não era moral nem conhecimento: Pareyson parte, pelo contrário, de um conceito pessoalista de unitotalidade da pessoa (...). Assim, tal como numa atividade especulativa existe empenhamento ético, (...) também na operação artística intervém uma moralidade (...) intervém o sentimento (...) e intervém a inteligência” (ECO, U. A definição da arte, pp. 15-16; ver também PAREYSON, L. Estética: teoria da formatividade, pp. 27-28).

${ }^{131}$ CIGLIA, F. P. Ermeneutica e libertà, p. 141 (grifos do autor).

${ }^{132}$ PAREYSON, L. Estética: teoria da formatividade, p. 67. 
goza da autonomia de uma coisa entre outras coisas, de pleno direito. Nesse sentido, a arte enquanto formatividade especificada é, em grau máximo, poiesis, produção ou "criação" - não ex nihilo, mas sim o trabalho formativo e construtivo que, admitindo uma matéria preexistente, elabora-a e conforma-a, nela desvelando potencialidades apenas latentes antes do início do esforço poiético. É, portanto, no sentido clássico do termo, "um produzir que dá forma, um fabricar que engendra, uma criação que organiza, ordena e instaura uma realidade nova, um ser". ${ }^{133}$ A arte se dá como um trazer a lume algo de peremptório e intrinsecamente válido, sendo uma efetiva realização, pois realizar quer dizer "não tanto existenciar um valor, singularizar um universal, concentrar um infinito, mas antes produzir uma existência válida, algo singular e ao mesmo tempo reconhecível por todos, exemplar, um ser definido, e ao mesmo tempo inexaurível e infinito". 134

\subsubsection{3.}

\section{Conteúdo e estilo}

Como exposto acima um dos móveis da concepção pareysoniana da forma artística é o esforço de recusa e superação da disjunção entre conteudismo e formalismo. Nesse sentido, Pareyson sustenta a tese, no que toca ao conteúdo, de que este, na arte, vem a ser o próprio artista: “certamente, o conteúdo da arte é a própria pessoa do artista, sua concreta experiência, sua vida interior, sua irrepetível espiritualidade, sua reação pessoal ao ambiente histórico em que vive, seus pensamentos, costumes, sentimentos, ideais, crenças e aspirações". ${ }^{135}$

Esse posicionamento pretende obter uma compreensão da arte que a insira no cerne da humanidade que a caracteriza. Também evita que a obra se encastele em uma impossível e abstrata autonomia, como se para se constituir como puro êxito devesse necessariamente excluir quaisquer finalidades e determinações outras. Do mesmo modo como a arte está presente em toda operação humana e está umbilicalmente ligada à vida, também a vida pode penetrar a arte, desde que quaisquer determinações nela compareçam enquanto motivo e ocasião de uma

\footnotetext{
${ }^{133}$ NUNES, B. Introdução à filosofia da arte, p. 20.

${ }^{134}$ PAREYSON, L. Estética: teoria da formatividade, p. 265.

${ }^{135}$ PAREYSON, L. Estética: teoria da formatividade, p. 30.
} 
vontade de arte. ${ }^{136}$ Deste modo, a autonomia da arte se resguarda mesmo quando a ela se mesclam direcionamentos outros. Do mesmo modo como atividades extraartísticas, movidas por um profundo sentido formativo, podem se impor à consideração de seu cumprimento também como um êxito artístico, também na arte se pode visar a outros fins, no interior da formatividade especificada e fazendo a justiça à espiritualidade que ali empenha todo seu mundo pessoal. Pareyson recorda que

a própria suficiência da arte implica uma funcionalidade sua: na arte, precisamente através do ato que a especifica, derrama-se a vida inteira, com todos os seus valores e todas as suas atividades, cada uma das quais mantém intacta sua própria natureza, muito vivas as próprias pretensões, ativos os próprios significados. Se a obra de arte não aceita valer senão como forma, isto não significa que ela se reduz a ser somente forma: ela é, ao mesmo tempo, uma forma e um mundo; uma forma que não exige valer senão como pura forma e um mundo espiritual que é um modo pessoal de ver o universo. ${ }^{137}$

Assim, tem-se que, ao mesmo tempo em que pura forma,

a arte é concebida como manifestação de pensamentos, atos de fé, aspiração política, ato prático, utilidade espiritual e material, visto que ao fazer arte, o artista introduz (direta ou indiretamente) sua concepção de mundo e suas próprias ideias morais e vitais na obra. ${ }^{138}$

Diretamente ligado a esta questão está o peculiar conceito pareysoniano de estilo. No formar do artista se empenha toda sua espiritualidade. É sua inteira personalidade, sua visão da realidade, valores, conhecimentos, inclinações que se põem em marcha na prática artística, consubstanciando-se num modo particular e concreto de formar, num estilo. Este outra coisa não é que a uma espiritualidade singular e irrepetível enquanto se faz um modo igualmente singular e irrepetível de formar. Logo, não se trata de escolha ou de mera invenção: "uma determinada

\footnotetext{
${ }^{136}$ PAREYSON, L. Por "vontade de arte", não se deve entender a vontade prática, o desejo deliberado e consciente, o qual pode mesmo faltar ao artista, sem que por isso se possa dizer que ali falte uma intencionalidade formativa. A expressão deve ser entendida no sentido de que, ao assumir uma intenção formativa, a espiritualidade da pessoa orienta todos os seus atos segundo esta intenção. Trata-se de um ato "profundo e total" que se reflete em toda a espiritualidade em questão (cf. PAREYSON, L, Estética: teoria da formatividade, p. 26).

${ }^{137}$ PAREYSON, L. Os problemas da estética, p. 44 (grifos do autor).

${ }^{138}$ OLIVEIRA, R. G. A obra de arte como um fato hermenêutico-ontológico, p. 43. Ver também PAREYSON, L. Problemi dell'estetica I. Teoria, pp. 134-136.
} 
espiritualidade é o seu estilo, porque basta que essa assuma direção formativa e se torne vontade de arte para que subitamente reclame o estilo que lhe é congenial, antes, torne-se esta mesma este estilo particular". ${ }^{139}$

\subsubsection{4.}

\section{A matéria na arte}

Igualmente essencial à compreensão da forma artística, a matéria assume contornos particulares à luz da formatividade, sendo entendida na arte como fisicidade sensível. Segundo Pareyson, a "extrinsecação" física é essencial à arte e toda obra de arte apresenta uma sua necessária dimensão material. ${ }^{140}$ A matéria é o substrato sobre o qual o ímpeto formativo opera, transformando-o, e é inerente a toda obra de arte, mesmo às que não se confundem com seu suporte físico, como as literárias e musicais: os sons de que um compositor dispõe e que organiza segundo um sentido musical, as palavras da língua que o poeta ou romancista combina, são, nesse sentido elementos materiais. ${ }^{141}$

Segundo Pareyson, a fisicidade se exige porque é só por meio da apropriação de uma matéria física que ela se pode especificar e distinguir da artisticidade em geral. Uma obra de pensamento, por exemplo, constitui-se indubitavelmente como forma, mas não poderia ter nesse aspecto formal o critério

\footnotetext{
${ }^{139}$ PAREYSON, L. Problemi dell'estetica I. Teoria, p. 133.

${ }^{140}$ Acompanha-se aqui a tradução de extrinsecazione por "extrinsecação", proposta na tradução brasileira de Os problemas da estética, em oposição ao uso de "exteriorização" (ver PAREYSON, L. Os problemas da estética, p. 149, nota do tradutor).

${ }^{141} \mathrm{Na}$ questão da fisicidade da arte, a teoria da formatividade se põe em franca oposição à perspectiva crociana, na qual a noção de figuração meramente interior se aplicava a todas as artes. O filósofo napolitano afirma que "a arte é visão ou intuição. $\mathrm{O}$ artista produz uma imagem ou fantasma; e quem aprecia a arte dirige o olhar para o ponto que o artista lhe apontou, olha pela fresta que ele the abriu e reproduz em si aquela imagem" (CROCE, B. Breviário de estética; Aesthetica in nuce, p. 35). Nessa concepção idealista e "mentalista", o elemento material não era necessariamente desconsiderado, mas as determinações materiais eram admitidas no âmbito da própria figuração interior, e assim tomadas em separado em relação ao ato de "dar corpo" à obra, exatamente o momento processual ou "técnico" que Pareyson privilegia e que unifica com a figuração. Assim, a despeito da admissão por Croce dos aspectos "físicos" resulta que, nele, "o momento da execução é totalmente secundário e inessencial, não possui outra missão que a de fixar algo que de outro modo a memória não poderia conservar" (GIVONE, S., Historia de la estética, p. 144; ver também CROCE, B. Breviário de estética; Aesthetica in nuce, p. 60).
} 
último de sua consideração, visto que responde a outras exigências. ${ }^{142} \mathrm{~A}$ arte exige uma matéria física porque somente esta pode constituir um valor artístico puro, sem que outros valores lhe disputem a primazia. Isto se dá porque a matéria não possui, em si mesma, significado humano, podendo ser formada pelo mero formar. ${ }^{143}$ A adoção de uma matéria se impõe pelo fato de que falta à arte a "matéria" que, na formatividade em geral, é dada pela atividade determinada em cada caso, com seu conteúdo e finalidade próprios, e que é aqui substituída pelo formar abandonado à sua pura estrutura inventiva. ${ }^{144}$

Matéria e conteúdo se põem assim como condições inelimináveis da formatividade especificada, e nela mutuamente implicadas, dado que "só o materialismo extremo da obra de arte consegue garantir o igualmente extremo espiritualismo de uma formatividade absolutamente purificada de finalidades e leis estranhas ao seu próprio exercício". ${ }^{145}$ Na confluência de conteúdo e matéria na forma artística se assenta a afirmação de que, nesta, espírito e corpo são um e o mesmo. ${ }^{146}$

${ }^{142} \mathrm{Ou}$, ao menos, não poderia tê-lo legitimamente como critério último. Para Pareyson, a consideração como "pura forma" de formas oriundas de atividades voltadas originalmente para outros fins (teóricos ou práticos) é a definição mesma do esteticismo (cf. PAREYSON, L., Os problemas da estética, p. 35).

${ }^{143}$ Cf. PAREYSON, L. Os problemas da estética, pp. 153-154.

${ }^{144}$ Cf. COPPOLINO, S. Estetica ed ermeneutica di Luigi Pareyson, p. 50. A matéria surge assim como o obstáculo sobre o qual se exerce a intenção formativa, como o substrato com o qual o artista se deve haver de modo a formar a obra. Saliente-se que, embora enfatize a componente material da obra tomada em sua corporeidade - as palavras do poema, o mármore da escultura - o conceito pareysoniano de matéria revela maior abrangência. Este acolhe as "diversas realidades que se chocam e se intersectam no mundo da produção artística: o conjunto dos 'meios expressivos', as técnicas de transmissão, os preceitos codificados, as várias 'linguagens' tradicionais, os próprios instrumentos da arte. Tudo isto está contido na categoria geral de 'matéria', realidade externa sobre a qual o artista trabalha" (ECO, U. A definição da arte, p. 18).

${ }^{145}$ CIGLIA, F. P. Ermeneutica e libertà, p. 137.

${ }^{146}$ Cf. PAREYSON, L. Estética: teoria da formatividade, p. 116. A realidade da arte como formação de uma matéria, em lugar de um conteúdo, e a consequente realidade da obra como "matéria formada", afastam-nas da concepção crociana, na medida em que a realidade espiritual do artista, que em Croce - como sentimento - é objeto de expressão, em Pareyson se constitui em sujeito da formação (cf. D'ANGELO, P., Il ruolo di Luigi Pareyson nell'estetica italiana del Novecento, p. 64). 


\section{2.}

\section{Arte e natureza}

O elemento inventivo próprio à arte, de inovação ontológica e produção de puras formas, confere à obra um caráter de necessidade, ou mais propriamente, de realidade "dada", de irrevogabilidade. A obra de arte se impõe como se houvesse estado sempre lá. ${ }^{147}$ Sua face de pura existência se assemelha à de um "ato sem ator" na expressão de F. Tomatis:

a pura existência é um ato sem ator. É, parafraseando Kant, a exibição de uma ideia da razão sem que a imaginação possa sintetizá-la ao entendimento. O mistério da obra é o abismo que escancara uma forma sem autor, uma ideia inconcebível, uma existência totalmente atual e sem palavras. ${ }^{148}$

Com base neste seu caráter, permite-se uma primeira aproximação da compreensão formativa da arte ao domínio da natureza. A obra de arte se assemelha a um ente natural na condição de gratuidade e aparente necessidade com que se dá. É o que leva Pareyson a indicar um "estreito parentesco" entre as obras de arte e as coisas da natureza:

Como as coisas da natureza, assim também as obras de arte possuem o traço de serem puras existências, que se dão inteiramente em sua presença física, simbolizando apenas a si mesmas, e nas quais tudo reside na semelhança sensível, sem remeter a profundezas escondidas e misteriosas. Mistério é sim a sua própria presença, profundidade e aspecto, e sua figura tem um rosto tanto mais impenetrável e distante quanto mais irrevogável e óbvia for a sua realidade. ${ }^{149}$

A consideração da atividade artística como produção de novas formas únicas e autônomas enseja assim, em Pareyson, uma reconsideração da bimilenar doutrina da arte como imitação da natureza. As duas noções em jogo nesta expressão demandam esclarecimentos de modo a que se capte o sentido que admitem na teoria da formatividade.

\footnotetext{
${ }^{147}$ FERRARIS, M. Un'estetica senza opere, p.101.

${ }^{148}$ TOMATIS, F. Pareyson: vita, filosofia, bibliografia, p. 51.

${ }^{149}$ PAREYSON, L. Estética: teoria da formatividade, p. 117.
} 


\subsection{1.}

\section{Arte e imitação}

Uma primeira e mais trivial afirmação de um princípio de imitação da natureza seria aquela calcada na ideia de reprodução, segundo a qual o artista produz um objeto em algum sentido semelhante ao real tomado por modelo. Perante esta questão, é útil a distinção proposta por Pareyson entre conteúdo, tema e assunto na obra de arte. O conteúdo, conforme tratado acima, é a própria personalidade do artista constituída enquanto modo pessoal de formar. $\mathrm{O}$ assunto é o argumento tratado, o objeto a ser narrado, descrito ou representado, enquanto o tema é o motivo, modo de ver ou sentimento inspirador do processo de formação. ${ }^{150}$ Assim, qualquer consideração da natureza ao nível de tema ou assunto, conquanto de todo legítima, não se pode considerar uma afirmação de caráter filosófico e de valor especulativo, mas somente programático ou crítico. As inúmeras possibilidades de “imitação da natureza" aí abertas não permitem uma compreensão da mesma como concepção geral de arte. Do mesmo modo, Pareyson reconhece no desenvolvimento histórico da ideia de que a lei da arte era a imitação da natureza uma progressiva apropriação que fez com que à expressão se fosse dando "o significado pretendido por uma poética, recomendando ora uma representação realista, ora uma figuração idealizadora, ora uma invenção fantástica, acabando logo por reduzi-la mais a programa de arte do que a lei estética". ${ }^{151}$ Deve-se perquirir, portanto, o eventual sentido filosófico de tal concepção, remontando ao conceito de imitação.

Pareyson dedica considerável atenção às vicissitudes históricas pelas quais passou o conceito de imitação - e sua contraparte, o conceito de criação - em sua aplicação à arte. Os dois conceitos se desdobram, à luz da consciência estética moderna, em adicionais pares antitéticos: a imitação, enquanto reprodução e passividade, seria própria a estética antiga; a criação, enquanto inovação e atividade, caracterizaria a modernidade. Do mesmo modo, tais conceitos

\footnotetext{
${ }^{150}$ Cf. PAREYSON, L. Os problemas da estética, pp 69-70. Toda obra de arte tem um conteúdo (a pessoa e espiritualidade do artista), mas os demais elementos podem faltar segundo diferentes poéticas animem o processo formativo em curso. Pareyson chama obras representativas àquelas que possuem assunto, tema e conteúdo; líricas àquelas em que o próprio tema é o assunto e abstratas aquelas em que só há o conteúdo (cf. ibidem, p. 70).

${ }^{151}$ PAREYSON, L. Os problemas da estética, p. 181.
} 
forneceriam os polos fundamentais da oposição literário/poética entre classicismo e romantismo e reproduziriam, em seu âmbito particular, a oposição filosófica entre realismo e idealismo, sendo assim consolidados como pontos extremos de uma oposição insanável, mas no entender de Pareyson igualmente insuficiente e artificiosa. É uma oposição de tal ordem que uma revisão histórico-conceitual poderia equacionar, buscando os justos limites de aplicação e a mútua implicação de cada conceito ao longo da história da estética (desvelando inclusive a gradual transmutação do conceito de imitação naquele de criação), e abrindo a possibilidade de uma renovada compreensão do fenômeno artístico. ${ }^{152}$

Analisando o conceito de imitação, Pareyson conclui que, a despeito de sua multifacetada onipresença histórica, seus sentidos fundamentais se resumem a três: no primeiro deles, a imitação é produção de imagens semelhantes à realidade tomada como modelo, e, pois, uma representação da natureza; no segundo, a imitação é produção sem um direto correlato real, mas calcada na noção de verossimilhança, e logo, tem por fito prolongar a natureza; por fim, no terceiro caso, a imitação é reprodução de um modelo ideal, ou idealização da natureza. Quanto ao elemento enfatizado em cada qual, o autor esclarece que

o primeiro conceito põe em foco, sobretudo, a relação entre a imagem e o modelo, e a concebe como relação extrínseca de semelhança; o segundo conceito se refere sobretudo à obra de arte em si, encontrando seu valor em sua intrínseca verossimilhança; o terceiro conceito concerne sobretudo ao modelo entendido como modelo ideal ou norma transcendente de beleza. ${ }^{153}$

Pareyson indica que no decurso histórico da imitação/criação estão simultaneamente presentes e implicados os elementos de uma autonomia e transcendência do mundo da arte face à realidade e uma necessária referência daquela a esta. Deve-se afirmar uma mediação entre imitação (como nexo entre arte e mundo) e inovação (como autônoma instauração de uma nova e distinta realidade), no sentido de uma "imitação-invenção" como a de que, segundo Pareyson, o pensamento de Vico dá exemplo. Tal mediação se impõe pela própria unicidade da estética, que deve dar conta das justas exigências de cada perspectiva. Assim, mais que no conceito de semelhança, é numa recuperação do conceito de verossimilhança, que considera a obra em si, ligada de modo menos

\footnotetext{
${ }^{152}$ Cf. PAREYSON, L., Problemi dell'estetica I. Teoria, pp. 28-30.

${ }^{153}$ PAREYSON, L., Problemi dell'estetica I. Teoria, p. 30.
} 
extrínseco ao mundo, que se deve encontrar o caráter de coerência interna e heterocosmicidade (como criação "poética" de um novo mundo, da arte como um “outro mundo"), tal qual se verifica na experiência artística. ${ }^{154}$

Logo, segundo Pareyson, o traço distintivo da arte não reside no tipo de relação que esta guarda com a realidade externa. A atenção ao modo particular, positivo ou negativo, segundo o qual uma forma artística se liga à realidade é essencial para o seu significado, e logo para sua interpretação, mantendo grande importância ao nível poético/crítico. Não obstante, nada tem a dizer quanto ao seu valor de arte, ao seu "ser-arte" propriamente dito. É o que suscita a afirmação pareysoniana de "que a arte copie ou transfigure, o essencial é que ela 'figure'; que a arte deforme ou transforme, o essencial é que ela 'forme'. (...) O essencial da obra de arte não consiste no ser imagem ou sinal, mas no ser uma coisa, um objeto, uma realidade". ${ }^{155}$

\subsubsection{1.}

\section{A arte imita a natureza}

Ao prover ao mundo novas formas, a arte apresenta aquele liame com a natureza cuja formulação remonta a Aristóteles, segundo o qual "em alguns casos, a arte completa o que a natureza não pode levar a termo, em outros imita a natureza". ${ }^{156}$ Nessa perspectiva a arte "é uma espécie de duplo da natureza; a operação artística se deve conceber como um prolongamento ou consumação da atividade natural". ${ }^{157}$ É nesse sentido que se deve compreender a orgânica continuidade que Pareyson assinala, por exemplo, entre as edificações humanas e sua instalação harmônica em meio e por sobre a paisagem natural quando, por exemplo,

as pedras da cidade edificada sobre o monte parecem prolongar as escarpas e a rocha, (...) e as igrejas, as torres, os campanários e os palácios habitam na paisagem, resplandecendo ali sem se destacar da paisagem, lançando aí suas raízes e prolongando as suas linhas, agregando a si o ambiente e animando-o ao mesmo tempo, em um feliz conúbio. ${ }^{158}$

\footnotetext{
${ }^{154}$ Cf. PAREYSON, L., Problemi dell'estetica I. Teoria, pp. 65 et seq.

${ }^{155}$ PAREYSON, L. Os problemas da estética, pp. 78-79.

${ }^{156}$ ARISTÓTELES, Física II, 8, 199a.

${ }^{157}$ PLAZAOLA, J. Introducción a la estética: historia, teoria, textos, p. 18.

${ }^{158}$ PAREYSON, L. Estética: teoria da formatividade, p. 119.
} 
O sentido genérico de que a noção de arte aí se reveste é de todo condizente com a inspiração profunda da teoria da formatividade; porém, aqui a noção de especificação permite uma compreensão mais precisa:

Aristóteles não se propôs o problema da "essência da arte", e, portanto, se era consciente da diferença entre objetos artificiais e produtos naturais, não se preocupou de constatar ulteriores diferenças no imenso universo dos objetos artificiais. Caso contrário, teria visto que o pintor plasma a forma do quadro na matéria de um modo muito mais profundo do que o faz um carpinteiro quando dá à madeira a forma de leito: o segundo constrói um objeto por adição e pela correlativa disposição das partes entre si, enquanto que o primeiro não se limita a construir um objeto inerte, mas produz um verdadeiro e genuíno corpo orgânico. ${ }^{159}$

Depreende-se do exposto, que é na arte, enquanto formatividade especificada, que a imitação da natureza se manifesta em sua plenitude, em que as formas adquirem o efetivo estatuto de organismos autotélicos e independentes, embora a formatividade institua um vínculo entre seus produtos e aqueles da natureza já desde suas mais modestas manifestações. Os produtos da técnica, por exemplo, imergem entre as coisas como as obras de arte, exercícios formativos que são, mas sua relação com estas e - por extensão - com o mundo natural se dá sob a égide antes do domínio que da solidariedade. A utilidade neles se antepõe à realidade de modo que não se podem dar como presença física tão-somente. ${ }^{160}$

Pode-se, enfim, afirmar categoricamente o estatuto da arte como imitação da natureza, não por qualquer referência representativa à realidade, mas porque nela se impõe como inovação, "seja porque acrescenta ao mundo natural um mundo imaginário ou heterocósmico, seja porque no mundo natural acrescenta, às

159 PAREYSON, L. Conversaciones de estética, p. 89. Esta afirmação é feita no contexto da exposição e análise que faz Pareyson de algumas ideias estéticas de Étienne Gilson.

${ }^{160}$ PAREYSON, L. Estética: teoria da formatividade, p. 269. Prossegue o autor: "é bem verdade que um utensílio, na sua nua e essencial conformidade ao fim, pode se tornar objeto de contemplação, e que as formas se podem sujeitar a instrumentos ou bens úteis, mas então no primeiro a mera utilidade é ultrapassada e incluída na consideração da perfeição estrutural e, no segundo, a utilização pressupõe ao menos a possibilidade de uma valoração estética, pois a forma só pode ser útil como forma, e não de outro modo, a menos que seja reduzida a matéria informe." (Em razão de imprecisões na tradução brasileira até aqui citada, proponho nova tradução deste trecho a partir do original italiano. Ver PAREYSON, L. Estetica: teoria della formatività, p. 281). 
formas que já existem, formas novas que, propriamente, constituem um verdadeiro aumento da realidade". ${ }^{161}$

\subsubsection{2.}

\section{Formatividade natural}

O paralelismo entre os dois domínios parece, por outro lado, supor que à formatividade que se manifesta em todo operar humano corresponde uma formatividade da própria natureza. Pareyson não discute diretamente, ao caracterizar a noção de formatividade, uma sua manifestação no âmbito do mundo natural, mas sem dúvidas a reconhece e dá por pressuposta. ${ }^{162}$ Alguns esclarecimentos podem contribuir a estabelecer-lhe o sentido.

Pareyson atribui a J. W. Goethe a mais fecunda meditação sobre os liames entre natureza e arte. No pensador e poeta alemão, destaca-se a constância de uma visão progressiva que ao longo de toda uma vida acentua o paralelismo entre os dois domínios. Em seus inícios românticos, Goethe tematiza a natureza como vitalidade orgiástica e incontida, imersa no processo de diuturna criação e destruição de seus produtos - formas incessantemente mutáveis - em que vida e morte se alternam eternamente. A arte recusa então qualquer regramento, em benefício da infinita e inconsciente espontaneidade do gênio. Já em sua fase "clássica", maior atenção passa a ser conferida aos aspectos regulares e constantes do operar da natureza, no caráter concluso e perfeito de suas formas, donde a arte passar a ser vista não mais como expressão de uma vitalidade caprichosa aparentada à de uma natureza caótica, mas como o esforço de reproduzir a legalidade que então se reconhece na natureza. ${ }^{163}$

Pareyson recorda que a mudança de abordagem dos liames entre arte e natureza em Goethe resulta de sua célebre viagem à Itália e de seu estudo científico da natureza. Ao tomar a consideração da natureza menos sob a égide da subjetividade e do sentimento em prol de uma abordagem de caráter científico e

\footnotetext{
${ }^{161}$ PAREYSON, L. Os problemas da estética, p. 81.

${ }^{162}$ Cf. MURA, A. La concezione estetica in Luigi Pareyson, p. 38. O sentido exato e a fundamentação filosófica de tal "pressuposição" e o porquê de a mesma dever ser apenas uma pressuposição e, logo, de Pareyson não tematizar diretamente o formar natural ao conceituar a formatividade, serão temas do capítulo seguinte.

${ }^{163}$ Cf. PAREYSON, L. Conversaciones de estética, pp. 143-145.
} 
cognitivo, a natureza principia a aparecer, na reflexão de Goethe, segundo os caracteres de imutabilidade essencial subjacente à mudança, sublimidade, eternidade e - de máxima importância neste contexto - legalidade. ${ }^{164}$ É a partir desses desenvolvimentos que Pareyson assinala em Goethe a percepção de uma efetiva formatividade da natureza. Esta se funda na intuição de uma "mão da natureza", manifestação operativa da força criadora da qual o poeta se sente partícipe. Trata-se de atestar o caráter operativo e dinâmico da natureza: uma força eternamente criadora que move e anima todas as coisas a partir de seu interior. Esta sua eternidade decorre, por sua vez, a um só tempo do caráter incessante de seu atuar e de seu operar segundo leis eternas. Percebe-se aqui o caráter regrado que se supõe e reconhece também na natureza, e é o que permite tomá-la à luz da formatividade. ${ }^{165}$ Ainda detendo-se sobre a visão de Goethe, Pareyson resume-a ao concluir que este

na natureza sente sobretudo a eternidade e a imutabilidade, acentuando-as ao ponto de senti-las como divindade e sublimidade, e que ainda quando participa na criatividade da natureza, a associa à sua legalidade, isto é, a concebe como uma formatividade que age segundo leis eternas e imutáveis. ${ }^{166}$

Tem-se aqui aquele nisus formativus de que tratava Goethe e o qual Pareyson convictamente acolhe. ${ }^{167}$ Diante deste poder formante da natureza, instaura-se a visão dinâmica de uma formatividade universal, a qual permite considerar toda a realidade enquanto produção de formas e onde, juntamente aos produtos humanos, "as formas naturais que contemplamos não são, em verdade, senão resultados de processos naturais de figuração". ${ }^{168}$

\footnotetext{
${ }^{164}$ Cf. PAREYSON, L. Estetica dell'idealismo tedesco III. Goethe e Schelling, p. 159.

${ }^{165}$ Cf. PAREYSON, L. Estetica dell'idealismo tedesco III. Goethe e Schelling, pp. 170-171.

${ }^{166}$ PAREYSON, L. Estetica dell'idealismo tedesco III. Goethe e Schelling, p. 171 (grifos do autor).

${ }^{167}$ Cf. PAREYSON, L. La natura tra estetica e ontologia, p. 10.

${ }^{168}$ MURA, A. La concezione estetica in Luigi Pareyson, p. 19. A formatividade em âmbito natural é aqui apenas afirmada, de modo a justificar a analogia entre arte e natureza do ponto de vista operativo, visível particularmente no processo artístico, como se discute a seguir. Uma efetiva fundamentação dessa afirmação, por seu turno, só é possível do ponto de vista de uma gnoseologia da interpretação, como a proposta por Pareyson, e que será tratada subsequentemente.
} 


\subsubsection{3.}

\section{Caráter não natural da arte}

A solidariedade verificada entre arte e natureza não deve, entretanto, dissimular as grandes diferenças existentes entre ambos os domínios. O vínculo entre produtividade na arte e na natureza, como salienta Ferraris, se instaura na mesma clave analógica que se manifesta também em outros pontos da estética pareysoniana, o que explica a paradoxal afirmação de que "a natureza é formatividade dispersa, a obra é formatividade concentrada; a sua máxima naturalidade coincide com a hipérbole da inaturalidade". ${ }^{169}$ As diferenças entre natureza e arte são, portanto, relevantes para o equacionamento do paralelismo em tela.

As obras de arte, por exemplo, alcançam um ponto de conclusão, um acabamento durável e, salvo circunstâncias particulares, definitivo, que falta por completo aos produtos da natureza, imersos num fluxo transformativo incessante em que a frustração da forma é um evento comum, e em que a dissolução é inevitável. A arte por sua vez, como esforço presidido por uma intenção pessoal, produz novas realidades, e como esforço humano, uma segunda realidade completamente nova em relação à realidade natural. Se, consoante à afirmação de Goethe, na natureza a criatura por vezes não chega a ser o que "devia" ser, mas resigna-se ao que "pôde" ser, a arte, voltada à culminação do seu processo, pode atuar sob a égide do "dever", em detrimento do "poder". ${ }^{170}$ No mesmo sentido, deve-se pensar a discrepância verificada no sentido de realidade de ambas. Contra a realidade "real" da natureza, a arte propõe uma realidade imaginária, fantástica, e que se põe, pois, num nível distinto, sem competição ou confusão entre ambas. É nesse sentido que se pode, em aparente reversão paradoxal da perspectiva ora exposta, afirmar que arte e natureza estão muito afastadas, pois

precisamente porque atua como a natureza, por isto justamente [a arte] não imita a natureza (...) porque a arte prolonga a natureza, precisamente por isto não fica fixada à vida real, mas antes cria uma nova realidade que vive por si mesma e segundo suas próprias leis. ${ }^{171}$

\footnotetext{
${ }^{169}$ FERRARIS, M., Un'estetica senza opere, p. 102.

${ }^{170}$ Cf. PAREYSON, L. Conversaciones de estética, pp. 146-147.

${ }^{171}$ PAREYSON, L. Conversaciones de estética, p. 145.
} 
Em verdade, o paradoxo se resolve atentando-se à complementaridade de suas opostas exigências, como faz o autor ao afirmar que

a natureza não é arte nem a arte é natureza; a criação artística é inatural precisamente porque é natureza condensada, e a natureza condensada não pode mostrar-se senão através da inaturalidade da forma artística. Mas, em outro sentido, a arte prolonga a natureza: sua lei é a harmonia que governa a criatividade cósmica. É a mesma força criadora da natureza vista na imutabilidade e necessidade de sua lei. ${ }^{172}$

Por isso, o elo entre arte e natureza é proposto por Pareyson como um jogo de oposições em que se institui entre ambas uma relação que é, a um só tempo, de unidade e de separação, de distinção e de continuidade, e de solidariedade e oposição. Se a arte remonta à natureza, a continuação da criatividade natural na formatividade humana atesta que a culminância da natureza é algo dela diverso. ${ }^{173}$ Pois a obra de arte é fruto do espírito e, nesse sentido, ultrapassa a natureza e dela se distingue. O espírito, no entanto, só produz e exerce seu poder formante se em algum grau se apropria do poder formante da natureza e o toma por modelo. ${ }^{174}$

O relevo que tais formulações de ascendência goethiana assumem, por um exercício de congenialidade, no interior da teoria da formatividade, se faz notar na análise pareysoniana da dinâmica da efetiva realização artística. ${ }^{175}$ Trata-se de inquirir em que sentido a noção de imitação do poder formante da natureza na produção de "puras formas" se faz realidade na processualidade ínsita a toda formação, e como natureza e pessoa se assemelham num exercício de formatividade que redunda na "novidade ontológica" que caracteriza a arte.

\subsection{2.}

\section{O processo artístico}

A realidade da arte revela "o poder do espírito humano, o qual, capaz de fazer com que haja produtos orgânicos e realidades vivas, pode também estender os confins do reino das formas acrescentando (...) às formas naturais as inventadas pelo

\footnotetext{
${ }^{172}$ PAREYSON, L. Conversaciones de estética, p. 149.

${ }^{173}$ Cf. PAREYSON, L. La natura tra estetica e ontologia, p. 12.

${ }^{174}$ PAREYSON, L. Conversaciones de estética, p. 148.

${ }^{175}$ A noção de congenialidade, como condição da aproximação às formas, será vista em mais detalhe ao se discutir a concepção pareysoniana da interpretação.
} 
próprio homem". ${ }^{176}$ Resta por esclarecer como a pessoa singular chega a instituir meras formas, simples presenças, e como isto se dá, uma vez que a obra não surge instantaneamente, mas ao fim de um longo processo calcado em tentativas e sob o risco de fracasso. Esta constatação do elemento pessoal e processual da arte convida a uma compreensão "fenomenológica" do processo artístico, dos meios, etapas e circunstâncias que envolvem o aparecer da obra. É Tomatis a salientar que em Pareyson a perquirição filosófica do processo artístico não se detém apenas sobre o momento "técnico" - embora também o contemple -, isto é, nos procedimentos empíricos de que o artista se vale na produção da obra. Antes, trata-se de perscrutar o processo interpretativo por meio do qual uma ideia em princípio informe e vaga assume uma forma definida no decorrer do processo, de como a forma se instaura no real, quando antes não existia. ${ }^{177}$

A forma artística se instaura como resultante de um processo formativo levado a cabo em seus próprios termos. Ausentes as finalidades externas e as leis gerais que subordinam a formatividade nas demais atividades, na obra de arte a própria regra individual se transmuta em lei, de modo que

a lei universal da arte é que na arte não há outra lei senão a regra individual. Isto quer dizer que a obra é lei daquela mesma atividade de que é produto; que ela governa e rege aquelas mesmas operações das quais resultará; em suma, que a única lei da arte é o critério do êxito. Em todas as outras atividades uma operação é bem sucedida enquanto é conforme à lei universal (...) Em arte, por outro lado, a obra triunfa porque triunfa. ${ }^{178}$

A obra de arte é um puro êxito, e como tal, deve dar a partir de si mesma a regra de seu fazer-se, provendo a própria lei que presidirá seu resultado. Isto implica alguma determinação oriunda da própria forma enquanto tal. Seu caráter de necessidade impede que sua produção seja um cego tatear e seu caráter de contingência exclui a possibilidade de uma determinação prévia absoluta. Neste sentido, é possível dizer que a obra de arte se faz por si mesma e, no entanto, o artista a faz. Trata-se de um processo em que

o descobrimento surge somente através dos ensaios e a obra acabada é uma maturação que pressupõe um processo de germinação e incubação, através do qual, mediante uma continuada sucessão de retificações, correções, reinícios, seleções,

\footnotetext{
${ }^{176}$ PAREYSON, L. Estética: teoria da formatividade, p. 117.

${ }^{177}$ Cf. TOMATIS, F. Pareyson: vita, filosofia, bibliografia, p. 47.

${ }^{178}$ PAREYSON, L. Os problemas da estética, p. 184 (grifos do autor).
} 
refazimentos, abandonos e substituições, a obra se define enquanto se vai decantando. ${ }^{179}$

O uso de expressões como incubação, germinação, maturação, evocativas do mundo natural e do domínio orgânico, não é casual, o que se patenteia na obsedante recorrência de analogias deste jaez no texto pareysoniano. Assim, à precedente concepção da forma como organismo se associa, de modo coerente, a consideração de seu devir em termos de desenvolvimento orgânico. É o que permite a Blanco Sarto afirmar que se está perante uma espécie de "biologia da obra de arte" e concluir que "a aproximação entre arte e natureza, obra de arte e organismo, era para explicar o caráter dinâmico da atividade artística, pois nenhuma das duas realidades, arte e natureza, se pode entender a fundo sem fazer referência a seu nascimento e a seu processo de formação". ${ }^{180}$ A mesma passagem anteriormente citada, no entanto, assinala igualmente o caráter de trabalho pessoal, bem como as hesitações, os rearranjos e os abandonos que podem acometer o desenvolvimento da forma e que em muito se afastam da visão de um desenvolvimento linear.

\subsubsection{1. \\ Esforço tentativo e desenvolvimento orgânico}

Uma tensão fundamental se instala na reflexão pareysoniana sobre o fazer do artista. Como ressalta D'Angelo, Pareyson critica no romantismo a recusa ou dificuldade em reconhecer o caráter processual e tentativo da prática artística, seu incessante recurso às faculdades críticas e intelectuais e a vígil consciência que se exige do artista em seu atuar. No entanto, é sem dúvida da herança romântica que Pareyson se vale ao afirmar o caráter orgânico do nascimento e desenvolvimento da obra. Na simultânea recusa e acolhida de instâncias peculiares ao romantismo se inscreve o paradoxo de compreender a obra a um só tempo como desenvolvimento orgânico e produção construtiva. ${ }^{181}$ A articulação entre os dois polos, - não apesar de seu paradoxo, mas em razão mesmo dele - é, no entanto, imprescindível à compreensão da gênese da obra. Esta articulação, do ponto de vista do influxo teorético de concepções alheias sobre a teoria da formatividade,

\footnotetext{
${ }^{179}$ PAREYSON, L. Conversaciones de estética, p. 111.

${ }^{180}$ BLANCO SARTO, P. Hacer arte, interpretar el arte, p. 91.
} 
pode-se ilustrar pelas figuras de Goethe (reiterando a herança romântica e o peculiar espírito de congenialidade com que Pareyson examina suas ideias) e de Paul Valéry. ${ }^{182}$

Pareyson retorna a Goethe de modo a examinar a ideia de um desenvolvimento "vegetal" da obra de arte, ou seja, como um processo que, dotado de uma enteléquia própria, admite uma teleologia interna, como o amadurecimento de um fruto ou o desenvolvimento de uma planta ou animal. Nesta leitura, o artista aparece como um simples meio, sede inconsciente de um processo que lhe escapa e ultrapassa. Este é "como o jardineiro, que não produz flores, mas as faz crescer belas e luxuriosas, com cuidado álacre e solerte", ${ }^{183} \mathrm{o}$ que supõe a paciência e a esperança como virtudes primordiais do artista, que se resigna a reduzir os obstáculos à eclosão da obra, sem que verdadeiramente a produza. A despeito do crescente valor atribuído pelo autor alemão ao exercício, apontado por Pareyson, e ao trabalho e ao esforço pessoal na arte, a primazia seria ainda de um elemento mais profundo e fundamental, a originária vitalidade da natureza. $^{184}$

A teorização de Valéry, por seu turno, é valorizada por Pareyson em razão da ênfase posta na dimensão operativa da arte, na acentuação das ações levadas a cabo pelo artista. A arte, para o poeta francês, aparece como um exercício, uma série de atos particulares, executados segundo uma ordem e um ritmo que rejeitam qualquer arbítrio, e que ganham relevo tal ao ponto de elevar o labor produtivo ao estatuto de uma obra de arte em si mesma, uma "poesia geral da ação", em detrimento até da própria obra resultante de tal esforço. ${ }^{185}$ Desta concepção decorre também um significativo apreço pelas regras, obstáculos e resistências impostas ao artista, as quais lhe constrangem e limitam as ações pelo rigor com

\footnotetext{
${ }^{181}$ Cf. D'ANGELO, P. Il ruolo di Luigi Pareyson nell'estetica italiana del Novecento, p. 68.

${ }^{182}$ Tanto Goethe como Valéry, mas também Flaubert e Poe, por exemplo, são tidos por Pareyson como "artistas-filósofos", os quais legaram contribuições teoréticas que, "além de atestarem uma experiência concreta de arte tal como dificilmente os filósofos teriam tido à sua disposição nos séculos precedentes, têm elas mesmas um caráter estritamente especulativo, que as torna preciosíssimas para indagar filosoficamente esta importante região da experiência artística" (PAREYSON, L. Os problemas da estética, p. 185).

${ }^{183}$ PAREYSON, L. Estetica dell'idealismo tedesco III. Goethe e Schelling, p. 194.

${ }^{184}$ Cf. PAREYSON, L. Estetica dell'idealismo tedesco III. Goethe e Schelling, pp. 193-196.

${ }^{185}$ Cf. PAREYSON, L. Problemi dell'estetica II. Storia, p. 57.
} 
que exigem obediência, e que negam ao fazer artístico qualquer facilidade ou espontaneidade, capricho ou arbitrariedade. Põe-se em relevo a dificuldade inerente à arte, ao mesmo tempo em que se minimiza o papel da inspiração e do abandono em benefício de uma concepção de arte como empenho voluntário a autoconsciente. Aqui, à impetuosa e incônscia genialidade se antepõe a laboriosa humildade do esforço alerta e constante, no qual o artista se reconhece efetivamente um autor, o responsável pela obra vinda a lume. ${ }^{186}$

Ambos os autores comparecem conjuntamente em um parágrafo esclarecedor, no qual o filósofo insiste na via de mediação que se devia buscar entre as dimensões do livre desenvolvimento orgânico e do esforço tentativo e construtivo:

\begin{abstract}
Quando era jovem fiquei fascinado com esta concepção goethiana (...) mas sentia que faltava alguma coisa, porque ela não levava em conta o fato de que a atividade humana é tentativa, e que a operação do artista é uma aventura que não se sabe como vai terminar, e que a obra começa a existir só quando foi feita. Não por isto o fazer do artista é isento de guia e de orientação (...). Procede, não propriamente segundo a lei do lírio, mas a descobre à medida em que vai fazendo: um fazer que inventa ao mesmo tempo o modo de fazer. É aquilo que Valéry vislumbrou num lampejo de gênio, mas não tematizou, une croissance naturelle d'une fleur artificielle - une fabrication artificielle qui a pris une sorte de devéloppement naturel. Busquei realizar esta ideia. ${ }^{187}$
\end{abstract}

Esta mediação é, recorde-se, mais que mera harmonização de instâncias teóricas opostas, uma exigência nascida da própria experiência de fazer arte, onde necessidade e liberdade se implicam mutuamente. $\mathrm{O}$ artista nunca age segundo um capricho cego, o que implicaria a impossibilidade de qualquer avaliação, de sua parte, do progresso e validade do esforço já executado; nem com plena posse da fisionomia da obra, o que reduziria seu trabalho a mera transposição, decalque material de uma forma previamente intuída em sua totalidade:

A característica de todo projeto não é nem a luz nem a obscuridade, nem a ordem nem o caos, nem a lei nem o acaso, nem a certeza nem a ignorância, mas uma mescla dessas duas ordens de coisas, com o que a aventura não é tão incerta que

\footnotetext{
${ }^{186}$ Cf. PAREYSON, L. Problemi dell'estetica II. Storia, pp. 40-45.

${ }^{187}$ PAREYSON, L. La natura tra estetica e ontologia, p. 12. A referência à "lei do lírio" evoca a afirmação de Goethe de que ao poeta não resta senão confiar-se "à lei segundo a qual florescem a rosa e o lírio" (ver PAREYSON, L. Estetica dell'idealismo tedesco III. Goethe e Schelling, p. 193).
} 
não tenha outra via que o acaso, nem a orientação é tão precisa que possa garantir antecipadamente o resultado. ${ }^{188}$

A prática artística se caracteriza por uma série de simultaneidades tensionais. Será invenção e execução, consistindo em seguir um projeto que se revela concomitantemente ao desenvolver-se da operação que o empreende. Será criação e descoberta, ao ter um verdadeiro e livre autor que, no entanto, procede rumo a um resultado que a ele se impõe e para o qual deve contribuir. Será, enfim, tentativa e organização, esforço contingente, dificultoso e acidentado para constituir uma forma que por sua vez supõe um desenvolvimento necessário, linear e orgânico. Esta "incerteza orientada" é a condição mesma do tentar, que institui assim uma "teleologia interna do êxito" em relação indissolúvel com a liberdade da iniciativa da pessoa. ${ }^{189}$

\subsubsection{2.}

\section{Spunto, forma formante e forma formada}

Cabendo ao artista "seguir a finalidade interna da mesma obra que ele ideou, como se fosse um germe que tende a se desenvolver em fruto maduro", ${ }^{190}$ põe-se a situação paradoxal de uma obra que só passa a existir uma vez completa, mas da qual alguma influência ou precedência operativa se deve afirmar, se se entende que a legalidade que por fim ostenta é sua própria regra de produção. Os conceitos de spunto, forma formante e forma formada buscam dar conta desta exigência.

Por spunto entende-se o ponto de partida, o "germe" ou "semente" do processo artístico e, nesse sentido, promessa e aviso da obra por vir. Trata-se de um estímulo, de natureza a mais variável, acolhido num ato já processual e votado ao formar. O spunto surge do encontro com a espiritualidade do artista e, com efeito, "o ato com o qual ele desperta a atenção do artista não se distingue do ato com que este aplica o seu poder na sua própria direção formativa". ${ }^{191}$ Isto explica

\footnotetext{
188 PAREYSON, L. Conversaciones de estética, p. 28. Pareyson recorda que para Croce "o processo artístico consiste no copiar uma imagem interna, invenção e produção, concepção e execução, são dois processos diversos e distintos no tempo" (PAREYSON, L. Os problemas da estética, p. 186).

${ }^{189}$ Cf. PAREYSON, L. Os problemas da estética, pp. 187-190.

${ }^{190}$ PAREYSON, L. Os problemas da estética, p. 190.

${ }^{191}$ PAREYSON, L. Estética: teoria da formatividade, p. 123.
} 
como o spunto nunca é anterior, mas se inscreve sempre já no interior de um processo formativo. Do mesmo modo, ele é a um tempo incompleto e completo, pois por um lado é muito menos que a obra futura; por outro, abriga a possibilidade do desenvolvimento que dele pode advir, desde que venha a ser inserido num processo de formação, processo este que ele próprio inaugura e promove. É, destarte, uma espécie de totalidade potencial.

A possibilidade de desenvolvimento que o spunto suscita, por seu turno, vem a ser aquela que institui a legalidade própria da obra. ${ }^{192}$ Como uma semente encerra, de modo latente, o desenvolvimento ulterior do organismo, assim o spunto guarda, incoativamente, o possível desdobramento futuro da forma. Mas assim como a semente não pode desenvolver-se senão num dado organismo, e não em outro, assim também o spunto não é mera sugestão de possibilidades dentre as quais o artista possa arbitrariamente escolher, mas supõe um caminho único e impositivo, o qual apenas se entrevê:

essa antecipação da forma não é propriamente um conhecimento preciso nem visão clara, pois a forma só existirá quando o processo se concluir e chegar a bom termo (...) Se essa é a natureza do processo artístico, urge dizer que a forma, além de existir como formada ao termo da produção, já age como formante no decurso da mesma. ${ }^{193}$

Destarte, a forma goza de um estatuto paradoxal, pois antes de existir concretamente como obra formada, já se anuncia como um "pressentimento dinâmico" que se apresenta ao artista, e ao termo da formação é o resultado que se torna o critério de seu julgamento. Atento à dificuldade de tal afirmação, Pareyson atesta, inobstante, que a forma age antes ainda de existir. Essa previsão e espera da forma é intraduzível em termos de conhecimento, não é um saber determinado, o que faria o processo incidir no rebaixamento, encontrável no neo-idealismo crociano, a mero esforço exterior e mecânico de transmissão ou transposição. O formador antecipa a forma, mas só conhece integralmente a norma que dirige seus atos quando dela não mais precisa, ao perceber que a seguira todo o tempo satisfatoriamente e a obra está feita. Este aspecto não-cogntivo da assim chamada forma formante é de fundamental importância. Como aponta Ciglia, o desafio em questão é o de dar conta de uma realidade "inconfigurável e inobjetivável, mas

\footnotetext{
${ }^{192}$ Cf. PAREYSON, L. Estética: teoria da formatividade, pp. 120; 123-124.

${ }^{193}$ PAREYSON, L. Estética: teoria da formatividade, p. 75.
} 
todavia real, (...) que pode ser somente aguardada e esperada pelo artista, pressagiada ou mesmo adivinhada" e que, não obstante, mostra-se como "uma presença bem viva, dotada, num certo sentido, de uma prepotente personalidade". ${ }^{194}$ É ainda Ciglia a esclarecer que

a eficácia operativa que esta [a forma formante] exerce sobre o artista que a acolhe se explica por um apelo e em um impulso à formação: a forma formante é tal, com efeito, exatamente porque reclama a alta voz ser formulada em uma precisa forma formada. ${ }^{195}$

Compreende-se que é este prenúncio da forma o que permite explicar a união indissolúvel entre procura e descoberta que se manifesta no tentar em geral, e no "puro tentar" da arte em particular: "O tender à descoberta, que está presente em todo buscar, se reduziria a mera confiança no acaso, se a busca procedesse por tateios, e se dispersaria em uma opaca certeza de posse, se a busca andasse com toda a segurança". ${ }^{196}$ Forma formante e forma formada guardam uma relação de unidade e distinção, na medida em que ambas são a mesma coisa, desdobrada nos momentos inicial e conclusivo de um processo que é a "progressiva verificação de sua identidade". ${ }^{197}$.

A teorização pareysoniana da forma formante evoca também a tensão atividade-receptividade, ou seja, o compromisso ontológico da meditação do autor, o que se nota pela inegável transcendência de que a forma formante goza em relação ao artista. É o que recorda Vattimo ao afirmar que "a transcendência da lei em relação à obra é indício do fato de que, na obra de arte, está em curso alguma coisa a mais que a simples atividade do artista". ${ }^{198}$ Eco, por sua vez, ao analisar a noção de forma formante, aponta as dificuldades metafísicas que parecem permeá-la: a ideia de uma obra que guie a própria produção, com o consequente risco da anulação do artista numa formação etérea. Afirma, nesse sentido, a necessidade de consideração unitária do processo: "a metafísica da figuração é equilibrada pela feição 'pessoalista' do pensamento de Pareyson (...): o ponto de partida apenas tem validade, assume todas as suas virtualidades e

\footnotetext{
${ }^{194}$ CIGLIA, F. P. Ermeneutica e libertà, p. 143 (grifos do autor).

${ }^{195}$ CIGLIA, F. P. Ermeneutica e libertà, p. 143 (grifos do autor).

${ }^{196}$ PAREYSON, L. Estética: teoria da formatividade, p. 74.

${ }^{197}$ PAREYSON, L. Conversaciones de estética, p. 94.

${ }^{198}$ VATTIMO, G. apud CIGLIA, F. P. Ermeneutica e libertà, p. 144.
} 
torna-se fecundo quando é cultivado, compreendido, feito por uma pessoa". ${ }^{199}$ A forma nada é sem a pessoa, a intenção formativa que dela se apropria. O artista não é mero espectador do fazer-se da obra, mas a faz e só ele pode fazê-la - e à sua maneira. Nesse sentido, o efetivo desenvolvimento orgânico da forma depende igualmente da pessoa. Os eventuais pressentimentos da forma

são pontos de partida de formação que, pelo simples fato de o serem e de consistirem numa espécie de premissas de uma possível figuração, pressupõem um crescimento orgânico segundo regras de coerência; mas estes pontos de partida só se tornam fecundos quando o artista os segura e os faz seus - e faz da coerência postulada pelo ponto de partida, a sua própria coerência, e, das várias direções a que pode aspirar, escolhe a que lhe é congenial e que, por isso, será a única realizável. ${ }^{200}$

Verifica-se assim em que sentido o fazer artístico se assemelha ao desenvolvimento orgânico em seu caráter semovente e autotélico. Do ponto de vista da forma, seu desenvolvimento prorrompe a partir do interior de si mesmo, por crescimento e maturação em lugar da adição de partes heterogêneas; seu desenvolvimento é linear, unívoco como o da semente ao fruto; do mesmo modo, ela permanece idêntica ao longo dos momentos de seu desdobramento. Afirmar, como faz Pareyson, que na formação "não há distinção entre projeto, operação e resultado"201 é afirmar uma forma que é princípio, meio e fim: simultaneamente impulso germinal, guia da produção e resultado acabado. Isto não impede, no entanto, que, do ponto de vista do artista, e com igual peso e relevância, este processo assuma a face tentativa, hesitante e problemática de todo empenho pessoal. ${ }^{202} \mathrm{~A}$ obra acabada se impõe, por fim, a seu próprio autor, e, ao colher-se aí sua autonomia e organicidade, percebe-se que

aquilo que no curso de sua produção era sugestão, projeto, tentativa, pressentimento, trabalho, construção, cálculo, êxito, aparece como germe, embrião, organização, finalidade, crescimento, desenvolvimento, espontaneidade, maturação: vê-se então que os esboços eram já a obra inteira em movimento e em condição de orientar o próprio artista que a estava fazendo, e que lá onde nada parecia estável e sólido vivia já um todo que reclamava o próprio acabamento. ${ }^{203}$

\footnotetext{
${ }^{199}$ ECO, U. A definição da arte, p. 19.

${ }^{200}$ ECO, U. A definição da arte, p. 19.

${ }^{201}$ PAREYSON, L, Estética: teoria da formatividade, p. 77.

${ }^{202}$ Cf. PAREYSON, L, Os problemas da estética, p. 191.

${ }^{203}$ PAREYSON, L, Problemi dell'estetica I. Teoria , p. 163.
} 


\subsubsection{3. \\ 0 artista e o gênio}

A dissociação entre as perspectivas da obra e do artista como uma dialética entre livre desenvolvimento e esforço produtivo dá azo, na estética de Pareyson, a uma reavaliação do lugar deste último, especialmente no que toca ao papel do "gênio criador" na arte, que é aqui revisitado. O ponto de referência pareysoniano aqui, como em outros momentos de sua reflexão, é a estética romântica alemã. Esta aprofundou e equilibrou a visão pré-romântica que entendia o gênio, sobretudo, à luz da ideia de irrupção da subjetividade, que, desconhecendo as regras clássicas, criaria por meio do entusiasmo e da emotividade antes do que pela vigilância reflexiva - valendo-se, pois, de forças em certa medida opacas ao próprio criador que as punha em marcha. Estavam em jogo, de uma parte, a rejeição do caráter regrado da arte, e de outro, a ausência de plena autoconsciência da parte do artista. $^{204}$ Tal discussão seria retomada, no contexto romântico, essencialmente a partir do diálogo com Kant, quem famosamente definiu o gênio como "inata disposição de ânimo pela qual a natureza dá a regra à arte" e, pois, como "um talento para produzir aquilo para o qual não se pode fornecer nenhuma regra determinada". 205

É notória a pertinência desta problemática à estética de Pareyson, estando a arte comprometida com a busca de uma regra particular, julgada sob o critério do êxito. Muitas teses oriundas de uma "estética da genialidade" encontram ressonância na estética da formatividade: por exemplo, o sentido infinito das obras, que em muito podem ultrapassar as intenções pessoais e conscientes do artista e a ausência de domínio absoluto deste sobre seu próprio atuar. ${ }^{206} \mathrm{E}$, contudo, alguns intérpretes salientam o que consideram um redimensionamento ou redução do gênio - como comunhão de arte e natureza - na estética de Pareyson, motivados por sua leitura de Valéry. ${ }^{207}$ Neste caso, são antes as ideias de uma exacerbada espontaneidade e de inconsciência e irreflexão que o filósofo

\footnotetext{
${ }^{204}$ Cf. DUARTE, P. Estio do tempo: romantismo e estética moderna, pp. 70-71.

${ }^{205}$ KANT, I., Crítica da faculdade do juízo, pp. 163-164.

${ }^{206}$ Cf. DUARTE, P. Estio do tempo: romantismo e estética moderna, pp. 78-79.

${ }^{207}$ Cf. FERRARIS, M., Un'estetica senza opere, p. 101.
} 
dissociará de sua visão operativa. Características de que a concepção goethiana do gênio dá claras mostras, segundo Pareyson. Para o poeta alemão

as operações do gênio são inconscientes e espontâneas: é a natureza mesma que fala através do canto do poeta e que opera através da mão do pintor. Há, na criatividade, um aspecto de inconsciência: um liame com as forças vivas e ocultas da natureza, tão profundo a ponto de não chegar à consciência, mas tão essencial a ponto de constituir aquela estimulação e orientação sem a qual o artista não chegaria a operar. Nisto consiste, propriamente, o gênio, que é, no artista, a natureza mesma que nele fala. ${ }^{208}$

O próprio Pareyson ressalta que tal concepção não impedia a valorização, por Goethe, do trabalho e da disciplina, do empenho e aprendizado técnico, bem como não lhe impediu o gradual reconhecimento da importância do exercício assíduo e pertinaz como alicerce dos grandes êxitos. Não obstante, tais elementos seriam em última instância secundários face àquela matriz inconsciente em que a arte continuaria a vitalidade natural. ${ }^{209}$ Pareyson julga que esta concepção calcada na afirmação de que na arte o espírito opera como a natureza e a natureza como espírito - visava a irmanar a contingência orgânica da produção à decisão e convicção do artista, com prejuízo da acidentalidade própria à arte e da limitação própria à pessoa. A dissociação entre estes âmbitos permite equacionar o problema. Por isso "os termos que importa conciliar não são a inconsciente espontaneidade e a consciência livre, mas, de modo mais operativo, o caráter tentativo da operação artística e a organização intrínseca ao bom resultado". 210

Resguarda-se, assim, uma dimensão cara ao personalismo pareysoniano, qual seja a da falibilidade e dificuldade próprias a todo empenho humano, sempre limitado e dependente. A seu ver, a visão romântica salientava na obra o seu parecer ter-se erigido sem dedicação, trabalho e fadigas, a qual redundaria, ao fim, na concepção vulgar que concebia o fazer arte como "o curso triunfal de uma criatividade absoluta e como o êxtase operativo de uma atividade ignara de

\footnotetext{
${ }^{208}$ PAREYSON, L., Estetica dell'idealismo tedesco III. Goethe e Schelling, p. 194, (grifos do autor).

${ }^{209}$ Cf. PAREYSON, L., Estetica dell'idealismo tedesco III. Goethe e Schelling, pp. 194-196. Ressalte-se, inclusive, que alguma forma de conjugação ou síntese entre os ímpetos inconscientes e espontâneos e a reflexão e a disciplina estão presentes nas principais doutrinas do gênio do primeiro romantismo alemão. Cf. DUARTE, P., Estio do tempo, pp. 80 et seq.

${ }^{210}$ PAREYSON, L, Estética: teoria da formatividade, p. 91.
} 
obstáculos e dificuldades, renovando no mito da inspiração e do gênio a ideia da $\theta$ cía $\mu \alpha v i ́ \alpha$ e do demônio". ${ }^{211}$ Para Pareyson, não há uma genialidade que se sirva do artista para criar, de uma natureza que crie através dele, mas é o próprio artista enquanto pessoa que, fazendo-se estilo, infunde toda a sua espiritualidade no ato de fazer arte, de formar, num processo que, longe de ser absolutamente livre, é marcado por uma "livre obediência" alerta, atenta e propositiva. É nessa perspectiva existencial que se encontra a genialidade como capacidade pessoal de não só viver autêntica e intensamente uma espiritualidade própria, mas de saber convertê-la num modo de formar, num estilo que a traduza, com todos os riscos inerentes ao processo. ${ }^{212} \mathrm{Em}$ suma, a visão de Pareyson acerca do artista se resume suficientemente se se tem em vista que:

contra a imagem do artista como gênio criador, Pareyson propõe a ideia do artista como formador, como um trabalhador da forma. Este não será um semideus ou um demiurgo, mas uma pessoa que intui, começa, corrige, rasura, tenta... e ao final, forma, acaba e - com um pouco de sorte - logra a obra de arte. ${ }^{213}$

Este capítulo buscou esclarecer o sentido em que a estética pareysoniana afirma uma solidariedade entre arte e natureza, a partir da concepção de que a arte (e logo, o artista) imita e continua certa "formatividade natural", a qual, no entanto, foi até aqui presumida antes que fundamentada. Uma justificação da mesma exigirá um exame da dimensão "receptiva" da estética da formatividade, exame que permitirá abordar questões ainda não tratadas, como a da beleza da natureza, e revisitar e reavaliar, sob alguns aspectos, a própria doutrina da imitação da natureza de que até aqui se tratou.

\footnotetext{
${ }^{211}$ PAREYSON, L., Os problemas da estética, p. 192.

${ }^{212}$ Cf. PAREYSON, L., Problemi dell'estetica I. Teoria, p. 135.

${ }^{213}$ BLANCO SARTO, P. Hacer arte, interpretar el arte, p. 114 (grifo do autor).
} 


\section{3 \\ Interpretação e natureza}

\section{1.}

\section{A teoria da interpretação}

Historicamente, a reflexão estética teria dado, segundo D'Angelo, mais ênfase à perspectiva do fruidor da obra de arte que ao ponto de vista do seu produtor. Por esta razão, salienta na estética de Pareyson o seu olhar dirigido aos aspectos produtivos da arte, sua ênfase no caráter dinâmico da obra e nos processos tentativos que lhe dão nascimento. ${ }^{214} \mathrm{O}$ que não impede, no entanto, que a teoria da formatividade dê considerável atenção ao contato e à apreciação das obras de arte, uma vez que Pareyson aborda a relação produção-fruição como composta de termos não só aparentados, mas contínuos, buscando irmanar os pontos de vista do artista e do leitor. ${ }^{215}$ Por isto mesmo, porém, e mantendo-se fiel a sua raiz operativa, sua concepção da experiência da forma será marcada também pela ótica do fazer, pelo dinamismo, o que leva Ferraris a observar que

é fácil reconhecer a singularidade desta estética hermenêutica, que aparece como um corpo estranho em respeito às outras teorias da interpretação que se orientam principalmente no sentido de uma estética da recepção. (...) Aquela de Pareyson permanece (...) o único caso de uma teoria da interpretação apoiada sobre a produção e não sobre a recepção. ${ }^{216}$

Os elementos de esforço construtivo, tentativa, e busca, constituirão igualmente o contato com a forma, e a interpretação assume, como via de acesso às obras em geral e à obra de arte em particular, papel tão importante quanto o da noção de formatividade para sua produção. Em verdade, é possível dizer, seguindo

\footnotetext{
${ }^{214}$ Cf. D'ANGELO, P., Il ruolo di Luigi Pareyson nell'estetica italiana del novecento, p. 68.

${ }^{215}$ Cf. BLANCO SARTO, P., Hacer arte, interpretar el arte, p. 173. Pareyson se vale do termo leitura para se referir ao acesso às obras de arte, independentemente de seu gênero ou matéria. Ler significa aqui "reconstruir a obra na plenitude de sua realidade sensível, de modo a que ela revele, a um só tempo, o seu significado espiritual e o seu valor artístico" (PAREYSON, L., Os problemas da estética, p. 201, grifos do autor).

${ }^{216}$ FERRARIS, M., Un'estetica senza opere, p. 98.
} 
D'Angelo uma vez mais, que estas são noções gêmeas, ou "faces de uma mesma moeda". Isto porque a interpretação mesma tem caráter formativo, enquanto reconstrói, da perspectiva do intérprete, o processo levado a cabo pelo formador. É, nesse sentido, o modo de conhecimento próprio aos objetos nascidos de empenhos formativos, como busca de adequação à forma. ${ }^{217}$ Ademais, assim como a noção de formatividade, inerente a uma filosofia geral da pessoa, mostra no domínio da arte sua máxima fecundidade, do mesmo modo a interpretação, no estudo da experiência artística, ganha particular relevo e evidência, de modo que Pareyson considera este um campo privilegiado para sua análise e para a verificação de seu valor, embora ela em muito o ultrapasse. ${ }^{218}$

Consoante essa visão, Ciglia nota que a questão da interpretação comparece a duplo título na estética pareysoniana: por um lado, e em caráter mais geral, no exame da raiz comum sobre a qual se apoiam as diversas dimensões da espiritualidade humana, em sua orgânica inter-relação e antes da sua especificação. Aí a interpretação estará associada ao todo da vida espiritual, com seu caráter formativo e sua abrangente esteticidade. Além disso, a mesma noção far-se-á notar na exploração, mais específica, da apreciação das obras de arte, desdobrando-se também numa análise do conceito de execução. ${ }^{219}$

\subsection{1. \\ Intuição e interpretação}

Uma primeira aproximação aos meandros da interpretação, patenteando já sua valência estética, se pode obter a partir do exame pareysoniano do conhecimento sensível, mais especificamente da noção de intuição. Ciglia destaca a relevância e oportunidade deste passo para a economia interna da teoria da formatividade - o mais importante, a seu ver, para a fundamentação da interpretação no seu trato com a arte, exatamente por voltar-se àquela esfera ainda pré-artística que a condiciona e possibilita. Assim,

para poder captar tanto a conexão quanto a diferenciação recíproca - para poder captar, isto é, o ponto de articulação - entre os diversos âmbitos da vida espiritual do homem (...) parece necessário remontar, como para trás, até o âmbito do

\footnotetext{
${ }^{217}$ Cf. D'ANGELO, P., Il ruolo di Luigi Pareyson nell 'estetica italiana del novecento, p. 70.

${ }^{218}$ Cf. PAREYSON, L., Verdade e interpretação, p. 70.

${ }^{219}$ Cf. CIGLIA, F. P. Ermeneutica e libertà, p. 145.
} 
conhecimento sensível, que representa, segundo uma tradição consolidada, o terreno de cultura originário e comum dentro do qual se radicam igualmente tanto a dimensão do conhecimento quanto a da arte. Neste contexto problemático, a noção de intuição desempenha, historicamente e teoreticamente, um papel absolutamente privilegiado pelo fato de possuir pleno direito de cidadania seja no âmbito gnosiológico, seja no estético, representando, melhor ainda, uma espécie de fundamental ponto de mediação entre um e outro. ${ }^{220}$

Ao considerar a noção de intuição, Pareyson privilegia duas linhagens teoréticas: uma alemã, que vai de Baumgarten a Kant, e uma italiana, que vai de Vico a Croce. Na primeira delas, tem-se em Baumgarten uma redução gnoseológica da sensibilidade (como conhecimento inferior), o qual engloba a título de conhecimento confuso também os elementos passionais. A inventividade própria à arte é, por sua vez, vista em termos metafísicos, de modo que produção e fruição encontram-se justapostas, mas sem um nexo orgânico. Kant por sua vez se vale da distinção - herdada da estética do século XVIII - entre sensibilidade (faculdade cognitiva) e sentimento (faculdade estética), mas mantendo-os separados e associando a arte e a beleza apenas ao último, de modo que no sistema kantiano o conhecimento não tem dimensão estética, nem o sentimento tem dimensão cognitiva. O sentimento mantém com a produção artística a mesma relação exterior que, em Baumgarten, mantinham produção e cognição sensível, e a estética kantiana da produção (gênio) não se liga à da contemplação. ${ }^{221}$

As dimensões que nos pensadores germânicos apareciam separadas são unificadas nos italianos. Vico, com a doutrina da "primeira operação da mente", afirma o sentimento como mediador entre invenção e sensibilidade. A sensibilidade é sempre, e ao mesmo tempo, sensação e sentimento (aporte cognitivo e resposta pessoal) e é indissolúvel da fantasia como poder figurador daquelas reações sentimentais mesmas que acompanham toda sensação e do engenho como faculdade de invenção - o conhecimento é sempre inventivo e estético. Croce desenvolve a visão de Vico em sua doutrina da "forma auroral do conhecimento", na qual, suprimido o elemento da sensação em benefício do puro sentimento que é figurado pela imagem intuitiva, tem-se nesta última uma

\footnotetext{
${ }^{220}$ CIGLIA, F. P. Ermeneutica e libertà, p. 146 (grifos do autor).

${ }^{221}$ Cf. PAREYSON, L., Problemi dell'estetica I. Teoria, pp. 90-93. Como se verá adiante, esta separação kantiana entre instâncias produtivas e contemplativas será revisitada - e questionada por Pareyson.
} 
absoluta criação. A intuição, primeiro modo de conhecimento, só conhece algo na medida em que o cria e, sendo a obra de arte nada mais que intuição, há uma identificação total entre produção e fruição artística. ${ }^{222}$

Pareyson julga que estas concepções lançam em profundas dificuldades um esforço de compreender a arte como um empenho humano entre outros, inserido no todo da vida espiritual, e ao mesmo tempo resguardá-la em sua autonomia:

\begin{abstract}
Por um lado a arte perde todo seu caráter cognoscitivo, visto que o conhecimento não tem nenhum caráter estético, e por outro a arte é de si a aurora do conhecimento, no sentido de que o conhecimento imediato é intuição criativa; por um lado não há nenhum nexo entre arte e conhecimento porque o conhecimento não é estético, e por outro a primeira forma de conhecimento exatamente enquanto estética, é artística. (...) No primeiro caso nada é arte, e no segundo tudo é arte: em ambos os casos a arte é impossível na sua especificação característica. ${ }^{223}$
\end{abstract}

A solução pareysoniana busca mediação entre as ideias de transcendência da arte em relação ao conhecimento e de esteticidade do mesmo. Pareyson defende a inseparabilidade de sensação e sentimento na intuição, que não será idealística criação absoluta, mas terá um referente receptivo, um conteúdo cognitivo, o qual não obstante será sempre acompanhado de uma reação sentimental. A intuição não supõe momentos, e logo exclui uma relação de causalidade entre seus "elementos" - antes trata-se de um ato unitário que é receptividade-atividade (imagem de uma coisa, logo conhecimento; expressão de uma emoção, logo sentimento). A intuição não cria seu próprio conteúdo, pois o sentimento supõe um estímulo (spunto) que o matiza afetivamente - e aqui se mostra de modo flagrante a distância entre a perspectiva ontológica de Pareyson face à idealista de Croce. Daí decorrem consequências de grande valor para a teoria da formatividade. $O$ caráter sentimental inerente a toda intuição garante a expressividade e esteticidade de todo conhecimento, mas, ao referi-lo à sensação rejeita a criatividade e a artisticidade (em sentido crociano). Ao mesmo tempo, como nexo indissolúvel de referência à coisa segundo a constituição da pessoa, em que uma só se manifesta enquanto se manifesta a outra, o conhecimento sensível se constitui como interpretação in nuce. Como resume Pareyson:

\footnotetext{
${ }^{222}$ Cf. PAREYSON, L., Problemi dell'estetica I. Teoria, pp. 94-97.

${ }^{223}$ PAREYSON, L., Problemi dell'estetica I. Teoria, pp. 97-98.
} 
na intuição o sentir é tal só no figurar, de sorte que não há representação senão como figuração, isto é, não há receptividade sem atividade, e o figurar inclui sempre um sentir, de sorte que não há figuração senão como transfiguração, isto é, não há atividade sem receptividade. Na intuição, pois, a receptividade se prolonga na atividade e a atividade é desenvolvimento de receptividade, em um único processo de conhecimento e de expressão que, enquanto tal, é já, germinalmente, interpretação. ${ }^{224}$

\subsection{2. \\ Interpretação como encontro de pessoa e forma}

A interpretação supõe um interpretado e um intérprete. Assim, se constitui como o "encontro de uma pessoa com uma forma". ${ }^{225}$ Mais propriamente, Pareyson define a interpretação como uma "forma de conhecimento na qual, por um lado, receptividade e atividade são indissociáveis e, pelo outro, o conhecido é uma forma e o cognoscente é uma pessoa". ${ }^{226}$ Do ponto de vista do interpretado, o autor defende que "apenas como forma uma coisa é interpretável e 'visível' e somente em uma forma culmina a interpretação como figuração". ${ }^{227}$ Como empenho pessoal, e como o exame do conhecimento sensível já sugeria, a interpretação será sempre expressiva do intérprete na mesma medida em que for reveladora da coisa a interpretar. Segundo Pareyson, "a independência do interpretado e a personalidade do interpretante não constituem obstáculos para a interpretação, mas são a única condição possível para ela". ${ }^{228}$

Não obstante seu caráter expressivo - e em razão dele, aliás - a interpretação é conhecimento, e mais, é a única forma de conhecimento de que dispõe o homem, no entender de Pareyson. ${ }^{229}$ A pessoa só pode conhecer como acolhida de um spunto, de uma sugestão ou ocasião, que só se constitui como tal enquanto é ativamente acolhida: "do ponto de vista de uma atuação humana considerada 'formativa' (...) o próprio progresso cognoscitivo configura-se como troca contínua entre os estímulos que a realidade nos oferece como "pontos de

\footnotetext{
${ }^{224}$ PAREYSON, L., Problemi dell'estetica I. Teoria, p. 105.

${ }^{225}$ PAREYSON, L., Os problemas da estética, p. 225.

${ }^{226}$ PAREYSON, L. Estetica: teoria della formatività, p. 180.

${ }^{227}$ PAREYSON, L., Estética: teoria da formatividade, p. 184.

${ }^{228}$ PAREYSON, L. Estética: teoria da formatividade, p. 181.

${ }^{229}$ PAREYSON, L. Estética: teoria da formatividade, p. 172.
} 
partida' e as propostas que a pessoa lhes acrescenta para lhes dar forma". ${ }^{230}$ Esta troca contínua, por seu turno supõe um equilíbrio entres as instâncias envolvidas. Finamore recorda que

É propriamente este equilíbrio entre a forma e a pessoa, entre receptividade e atividade, que permite afirmar a interpretação seja como "ressonância" do objeto na pessoa, seja como "sintonização" da pessoa com o objeto: a ressonância tem razão de ser na medida em que, como estímulo, proposta, mensagem, seja captada, e por isso mesmo exige uma sintonização, que encontra o seu pleno significado no sujeito aberto a receber, a escutar. ${ }^{231}$

Com base no exposto, duas características decisivas da interpretação avultam. De início, a necessidade de uma "harmonização" entre conhecedor e conhecido, a qual não se funda somente na sua pessoal intenção interpretativa. Pareyson põe em relevo, em vários passos de seus escritos, a importância de uma relação de congenialidade entre pessoa e forma. Trata-se de uma "sintonia" que, para além do mero desejo de interpretar, facilita (ou dificulta ou mesmo impossibilita, por sua ausência) um encontro profícuo entre intérprete e interpretado. Certas espiritualidades (pessoais ou epocais) se adequam mais facilmente a certas formas e são mais repelidas por outras - logo, não se aproxima com igual facilidade e desenvoltura a qualquer obra artística, pessoal, moral, histórica, etc.. E não obstante, a congenialidade pode em grande medida ser exercitada e buscada, desenvolvida onde antes era diminuta, através de um esforço pessoal de penetração, fundado na maleabilidade própria à pessoa. ${ }^{232}$

A interpretação, além disso, será um conhecimento sempre tentativo e jamais exaustivo, e do mesmo modo que a produção de formas admite o risco constante do fracasso, também ela dar-se-á somente sob a ameaça constante da incompreensão. Para afastar tal risco, a atividade do intérprete deve supor o

\footnotetext{
${ }^{230}$ ECO, U. A definição da arte, p. 24.

${ }^{231}$ FINAMORE, R. Arte e formatività, p. 76.

${ }^{232}$ Cf. PAREYSON, L., Estética: teoria da formatividade, pp. 234-235. Considerando a experiência especificamente artística, por exemplo, Pareyson nota que, em razão da congenialidade "não é possível ser intérprete, executante, crítico igualmente bom de todas as obras: cada pessoa tem os defeitos das próprias virtudes e cada forma de inteligência tem as lacunas correspondentes à sua penetração. (...) Seria antes motivo para se desconfiar do pianista que pretendesse executar igualmente todos os autores ou do crítico que presumisse ser juiz igualmente penetrante de todas as obras" (ibidem, pp. 233-234).
} 
respeito pela autônoma integridade do interpretado, num efetivo diálogo congenial. O movimento da parte do conhecedor, que se dirige e perscruta a forma, deve querer acessar e explicitá-la em si mesma, em sua particular fisionomia e caráter, sem querer se sobrepor a ela pela lógica da "dominação", nem enrijecê-lo pela recusa do único "órgão" de que dispõe para acessá-la. ${ }^{233}$

Vê-se que na interpretação, naturalmente, é a pessoa em sua unitotalidade que está em jogo. Logo, para além do caráter estético e intelectual, a interpretação também conclama a dimensão ética sob dois aspectos: cabe ao intérprete, por um lado, o interesse, o esforço e o empenho requeridos pela tarefa; por outro, um reconhecimento de seus limites e da existência e legitimidade de interpretações outras que a sua - o que permite afirmar que subjaz à teoria da interpretação uma espécie de "ética do diálogo". ${ }^{234}$

\subsection{3.}

\section{A interpretação na arte}

A interpretação da obra de arte impõe uma série de desafios a quem a busque, em grande medida por seu caráter de coincidência de aspectos físicos e espirituais. A realidade material da obra distingue sua interpretabilidade daquela que lhe era atribuída, por exemplo, nas hermenêuticas neo-hegelianas (da qual a de Croce é aqui o exemplo mais imediato). Tais correntes veriam

na interpretação como revitalização a única possibilidade para a obra, enquanto espírito objetivado, de existir concretamente, sem perder-se no olvido da história. Em Pareyson a vida da obra, capaz como é de irradiar-se na infinidade das suas interpretações, é muito mais potente que na visão de uma hermenêutica historicista. Exatamente porque o espírito, na arte, se resolve totalmente em physis, não é possível entender a execução como um aporte espiritual externo. (...) A exegese não é nunca desmaterialização da obra: toda a multiplicidade das significações que esta faz emergir vem inscrita sobre o seu corpo. ${ }^{235}$

$\mathrm{Na}$ sua vigência de forma, a obra se mostra um exemplo extremo daquela inexauribilidade que marca a compreensão ontológica pareysoniana: nela, uma personalidade (a do artista) interpreta o mundo, ou seja, trata-se de uma infinitude

\footnotetext{
${ }^{233}$ Cf. PAREYSON, L., Estética: teoria da formatividade, pp. 174-175; ver também CANEVA, C., Bellezza e persona, pp. 101-102.

${ }^{234}$ Cf. BLANCO SARTO, P., Hacer arte, interpretar el arte, pp. 213-214.

${ }^{235}$ CARCHIA, G. Esperienza e metafisica dell'arte, p. 83.
} 
que interpreta outra infinitude no ato mesmo em que, como modo de formar, interpreta uma matéria, a qual, nesse sentido, é, mais do que contém, esse profundo significado espiritual: "o artista não se exprime senão por aquilo que $f a z$, e a obra não fala senão por aquilo que é; no fazer arte, exprimir é a mesma coisa que fazer, e na forma ser e dizer são uma só coisa". ${ }^{236}$ Como pura forma, sem finalidades ou constrições externas e dando-se como simples presença física, a obra constitui um âmbito de máxima interpretabilidade. Como matéria formada, a obra assimila sua valência espiritual à sua existência física. É o que salienta Carchia ao recordar que a noção de aparência, corrente no idealismo, está ausente da estética de Pareyson, na medida em que a matéria não é suporte, veículo ou máscara do sentido, mas o corporifica. ${ }^{237}$

Uma obra de arte é, simultaneamente, uma coisa e um mundo. Como tal, encerra infinitos aspectos, cada um dos quais a revela inteira, de modo que uma interpretação possa captá-la toda a partir da perspectiva visada. Ao mesmo tempo, nenhum aspecto a esgota, de modo que interpretação alguma jamais se possa crer como última, irretocável e definitiva. Na obra de arte se manifesta de modo exemplar o caráter de inesgotabilidade que perpassa, na "ontologia hermenêutica" pareysoniana, a relação da pessoa com o ser. Não por acaso, é antes de um exemplo artístico - mais especificamente, o da execução musical - que o autor se vale, ao analisar, num contexto filosófico mais geral, este aspecto de uma ontologia do inexaurível.

Pareyson recorda que a verdadeira existência de uma obra musical é sonora, mas que esta só se pode dar a partir de uma execução (logo, de uma interpretação) pessoal. A execução é reveladora na medida em que tenciona realizar a obra tal qual é, mas não pode senão ser expressiva enquanto realizada por uma personalidade singular. Assim, quem a ouve pode, com toda a razão, afirmar ter ouvido a obra. Não obstante, inúmeras outras execuções, pelo mesmo ou por outros executantes, lhe podem desvelar outros aspectos, nuances, sentidos. As muitas execuções não são aproximações imperfeitas a uma pretensa obra arquetípica, e por isso mesmo, inatingível, mas o meio pelo qual a realidade da

\footnotetext{
${ }^{236}$ PAREYSON, L., Problemi dell'estetica I. Teoria, p. 184 (grifos do autor).

${ }^{237}$ CARCHIA, G., Esperienza e metafisica dell'arte, p. 80.
} 
obra se dá. ${ }^{238}$ Vê-se que, embora a interpretação capte a obra inteira, esta sempre transcende suas execuções-interpretações, na medida em que é a norma de todas, e portanto não se reduz a elas. Entre uma obra e uma sua execução há sempre identidade e transcendência. ${ }^{239}$ Uma teoria geral da intepretação, a qual necessariamente inclui a interpretação da arte, só pode convidar, pois, a um esforço infinito. $^{240}$

Não somente a infinitude da obra está em jogo na experiência da arte, mas igualmente a da pessoa interpretante. Se o esforço interpretativo é incapaz de esgotar a riqueza da forma, que sempre permite novos ângulos de abordagem,

${ }^{238}$ Cf. PAREYSON, L., Verdade e interpretação, pp. 70-71. O filósofo reconhece aí uma das diferenças decisivas entre sua estética e a de Croce. A ausência, neste, de um conceito de interpretação-execução marcaria a distinção entre uma filosofia da pessoa e uma do espírito universal, pois “o espírito não 'interpreta' nem 'executa', porque ou 'cria' novas obras ou 'reevoca' aquelas que criou”. (PAREYSON, L., Problemi dell'estetica II. Storia, p. 221).

${ }^{239}$ Cf. PAREYSON, L., Problemi dell'estetica I. Teoria, p. 184. Posto não se desenvolva aqui esta questão, uma vez que foge ao escopo deste estudo, é útil recordar que, segundo Pareyson, a noção de execução de modo algum se restringe às artes de "performance". A execução consiste em "avivar" a obra, torná-la presente enquanto forma em sua plenitude sensível. Engloba assim a decifração (quando o "chamar à vida" da obra exige a decodificação de uma linguagem cifrada, como na música), a mediação, (como a declamação da poesia ou a curadoria numa exposição), e a realização, quando o próprio fruidor executa pessoalmente a obra, na medida em que a reconstrói interiormente na sua realidade de arte (como se dá, por exemplo, na poesia, em que o leitor sempre precisa animá-la e sonorizá-la interiormente). Ainda que em dadas artes (ou em diferentes contextos de uma dada arte) possam faltar a decifração e a mediação, esta execução realizadora e pessoal está sempre presente, o que leva Pareyson a estender o conceito de execução a todas as artes (cf. PAREYSON, L., Os problemas da estética, pp. 208 et. seq.) Dupla é a importância desta concepção de Pareyson: por um lado, reitera o caráter já interpretativo e pessoal de toda uma série de atividades que apoiam e sustentam as experiências pessoais e singulares da arte; por outro, recorda que, a despeito de sua existência física, a obra de arte precisa de condições que the permitam manifestar-se em sua realidade plena, pois "a existência de uma pintura, no escuro, está tão distante da sua existência artística quanto o está uma partitura da execução pública de uma obra musical" (ibidem, p. 211).

${ }^{240} \mathrm{O}$ que vale para a arte vale, mutatis mutandis, para o plano mais abrangente da relação da interpretação face à verdade ontológica. Como processo inacabável, ela é "consciente de que não se pode possuir a verdade a não ser na forma de ter de procurá-la ainda, já que a interpretação não é a enunciação completa do subentendido, mas a revelação interminável do implícito" (PAREYSON, L., Verdade e interpretação, p. 97). Voltando à esfera da arte, se é sempre possível desvelar novos aspectos de uma obra, é lícito afirmar que toda leitura é um convite à releitura. 
novos aspectos a descortinar, revisar, corrigir ou aprofundar, do ponto de vista do intérprete também se articulam infinitos aspectos. Para além da óbvia multiplicidade quantitativa de interpretações segundo as inumeráveis pessoas singulares - cada uma das quais se empenhará no processo interpretativo segundo sua personalidade e situação - deve-se recordar que, como forma, a própria pessoa é já a cada momento uma infinidade de pontos de vista possíveis, e que no decurso do tempo pode assumir outras tantas possíveis perspectivas. Assim, mesmo do ponto de vista de uma pessoa singular num dado momento, interpretação alguma pode jamais ser cabal ou definitiva, pois já aí são duas infinidades incomensuráveis que se encontram. Como sintetiza Pareyson,

na definitividade irrepetível da pessoa há infinitos pontos de vista e modos de ver, e na determinabilidade inconfundível da forma há infinitos aspectos e perspectivas. Daí resultam infinitas interpretações possíveis, e o conhecimento é necessariamente marcado por esse caráter de multiplicidade inexaurível que constitui a interpretação como tal. ${ }^{241}$

Não se deduz daí que o processo interpretativo seja falho, imperfeito ou parcial no que toca ao acesso à obra em sua realidade, nem que, do ponto de vista da multiplicidade dos intérpretes, este se reduza a uma projeção subjetivista, como se nele se manifestasse tão-somente um olhar que se impusesse ao objeto visado. Pareyson acusa como um "falso dilema" a costumeira oposição entre uma unicidade incontornável - como se se devesse buscar uma interpretação única que colhesse a obra na sua "real fisionomia" apagando a personalidade do fruidor - e uma arbitrariedade relativista que tornaria a obra inacessível, pondo o intérprete previamente nela tudo quanto dela pudesse posteriormente retirar. Afirma, nesse sentido, que "a unicidade é da obra e não da interpretação, enquanto a multiplicidade é da interpretação e não da obra, uma vez que a obra permanece idêntica e igual a si mesma na multiplicidade das suas interpretações". 242

\footnotetext{
${ }^{241}$ PAREYSON, L., Estética: teoria da formatividade, p. 180.

${ }^{242}$ PAREYSON, L., Os problemas da estética, p. 234. No contexto filosófico italiano a partir do qual se pronunciava, Pareyson reconhecia nas estéticas de Croce e de Gentile as posições extremas figuradas no "falso dilema" supracitado: na perspectiva crociana, postulada uma única interpretação efetiva, impunha-se um esforço de impessoalidade para que a obra fosse reevocada, o que exigiria alguma forma de “esquecimento de si”. Já segundo Gentile, era a originalidade do
} 
É no exercício da congenialidade como base de um diálogo em que a pessoa busca uma respeitosa sintonia com a forma, que se esteia a possibilidade de uma intepretação pessoal e revelativa. A interpretação é interpretação da forma ao mesmo tempo em que feita por uma pessoa e só exprime a pessoa no mesmo ato em que manifesta a forma. Uma descrição do processo interpretativo é a chave para justificar este duplo caráter.

Em sua dinâmica peculiar, a interpretação se mostra sob duas faces: sendo um "movimento visando apreender o verdadeiro sentido das coisas, visando fixálo em uma imagem penetrante e 'traduzi-lo' em uma figura viva", 243 naturalmente supõe um termo, um momento de repouso em que se conclua. ${ }^{244}$ Sendo formatividade, é produção, e assim, busca por meio de tentativas apreender a realidade que tem defronte, por meio de figuras cuja adequação é testada continuamente contra a solicitação original da coisa. O processo interpretativo quer produzir uma forma que seja uma imagem adequada desta e, destarte, conhecê-la.

Enquanto movimento, a interpretação se dá sob a égide da dualidade entre uma solicitação ou spunto e os esquemas que dele tentam dar conta. Enquanto dura o esforço interpretativo, ambos se distinguem: o intérprete formula e refina os esquemas na busca de obter uma imagem fiel ao apelo formal que o solicita. Tal processo implica, formativamente, a produção/invenção constante de novas figuras e implica testes, tentativas, aproximações, verificações, revisões e mesmo recomeços. Enquanto repouso, se o processo é exitoso, dá-se finalmente a coincidência entre os termos, então não mais apelo e esquema, mas efetivamente coisa e imagem, efetivamente forma:

imagem e coisa, por conseguinte, se adequacionam enquanto verdadeiramente coincidem, pois então não há mais nenhuma distinção e dualidade entre a coisa interpretada e a interpretação que se lhe dá. A coisa é aquilo que se vê aí e que dela

intérprete a se impor, de modo que toda interpretação se tornava tradução, devendo a obra ser "refeita" a cada nova experiência da mesma (Cf. ibidem, pp. 201-202).

243 PAREYSON, L., Estética: teoria da formatividade, p. 180.

244 Saliente-se que mesmo este repouso, na medida em que é consideração de um processo dinâmico e que o colhe em seu dinamismo, não se reduz à mera passividade, pois nele o olhar "percorre a obra de lado a lado, circula através da lei de coerência que a mantém unida", sendo um estado ativo "que não tem nada do abandono e da perda de si, porque antes implica uma tomada de posse, uma afirmação de domínio” (PAREYSON, L., Os problemas da estética, pp. 207-208). 
se diz, ou seja, a imagem que dela se tem, pois aquilo que dela se diz é a coisa, e a imagem da coisa a transmite, a declara, a desvela, é-a. ${ }^{245}$

$\mathrm{Na}$ experiência, os dois aspectos do processo interpretativo se alternam e se implicam incessantemente, de modo que o movimento figurador sempre tenciona o repouso da posse, a qual por seu turno é sempre solicitação a um seu aprofundamento constante, e logo, convite ao movimento. ${ }^{246}$

\subsection{4.}

\section{Beleza e contemplabilidade}

O exame do esforço interpretativo suscita a consideração, por Pareyson, do lugar da beleza na vida espiritual. Conquanto Pareyson privilegie termos concretos, de pendor naturalista, como obra ou forma, a consideração dos mesmos traz a reboque imediatamente a questão da beleza, que goza de grande relevo em sua estética. A beleza será entendida em relação indissolúvel com a forma - mais ainda: como a própria forma em seu ser-forma, mais que como um seu atributo separável. $^{247}$

O processo interpretativo se conclui como adequação e coincidência entre imagem e coisa, no lograr ver a forma como forma, o que Pareyson chama contemplação. Antes que se analise esta noção, deve-se reiterar que "contemplabilidade e logo, beleza, não existem senão como resultado de produção". ${ }^{248}$ Logo, a despeito de seu caráter contemplativo, a beleza estará mais intimamente ligada à produção, pois só pode ser entendida como coroamento daquela produtividade que se manifesta duplamente - por um lado, no processo que engendra a forma e, por outro, no processo de sua interpretação. Deve ser buscada propriamente "ali onde o ponto de chegada da atividade formativa se torna, pela sua natureza mesma, o ponto de partida da busca interpretativa". ${ }^{249}$

Toda contemplação, na medida em que consiste no termo de um esforço, no repouso que sucede um movimento, suscita prazer e satisfação. Na forma, o ser

\footnotetext{
${ }^{245}$ PAREYSON, L., Estética: teoria da formatividade, p. 185.

${ }^{246}$ Cf. PAREYSON, L., Estética: teoria da formatividade, p. 184.

${ }^{247}$ Cf. BLANCO SARTO, P., Hacer arte, interpretar el arte, p. 260.

${ }^{248}$ PAREYSON, L., Problemi dell'estetica I. Teoria, p. 114.

${ }^{249}$ PAREYSON, L., Problemi dell'estetica I. Teoria, p. 160.
} 
contemplável equivale ao ser fruível, ou "contemplabilidade essencial coincide sem resíduo com a sua essencial fruibilidade e gozabilidade do mesmo modo que a contemplação é (...) tranquilidade imóvel e repouso desejado e esperado, gozo fruição, posse". ${ }^{250}$

Ao definir a beleza em termos de contemplação, Pareyson afirma trilhar terreno conhecido e situa sua concepção da mesma no quadro mais amplo das tentativas modernas de pensá-la em termos de correspondência e adequação entre as instâncias cognoscente e cognoscível. Do ponto de vista histórico como teórico, reconhece em Kant um precursor e fecundo formulador desta visão. A doutrina kantiana da "contemplação pura", afirmaria o caráter não-prático da experiência do belo: da parte do objeto haveria pura representação sem existência e da do juízo sentimento sem desejo - enquanto desejo e existência são intrínsecos à esfera prática e ao interesse que a caracteriza. De igual modo, a contemplação excluiria elementos teóricos: da parte do objeto haveria pura forma sem conceito, e do sujeito um puro juízo sem aporte do entendimento - enquanto aporte intelectual no sujeito e conceito no objeto são intrínsecos à esfera teorética e à finalidade objetiva, enquanto na experiência estética manifestar-se-ia somente uma finalidade subjetiva (puro juízo no sujeito correspondendo à pura forma no objeto). Ao analisar e interpretar a doutrina kantiana da contemplação pura, mais que à recusa, nesta, dos elementos teóricos e práticos, Pareyson valoriza a afirmação de uma "correspondência perfeita" entre o contemplante e o contemplado, somente à luz da qual ateoricidade e apraticidade mostrariam seu efetivo significado. ${ }^{251}$ É a partir desta linhagem teórica que Pareyson busca repropor formativamente a indissociabilidade entre contemplação e contemplabilidade no diálogo entre pessoa e forma.

\footnotetext{
${ }^{250}$ PAREYSON, L., Estética: teoria da formatividade, p. 187.

${ }^{251}$ Cf. PAREYSON, L., Estetica dell'idealismo tedesco I. Kant e Schiller, pp. 46-47. "Liberdade no contemplado, subtraído à existência e ao conceito, e liberdade no contemplante, subtraído ao desejo e ao entendimento: este é o conceito de contemplação que de Kant é transmitido aos seus continuadores, os quais the darão os mais diversos e variados desenvolvimentos, todos baseados, todavia, sobre o conceito de uma correspondência necessária entre contemplado e contemplante" (ibidem, p. 47). Ver também RUSSO, F., Contemplazione e interpretazione. L'estetica kantiana nell'analisi di Luigi Pareyson, p. 109.
} 
Pareyson identifica a beleza com a "contemplabilidade e fruibilidade da forma enquanto forma, que se oferece ao olhar que sabe fazer-se vidente e contemplante (...). Concluir a interpretação, contemplar um objeto, apreciar-lhe a beleza, são três expressões para indicar um só ato". ${ }^{252}$ A beleza se instala assim num campo intermediário, que não abandona a referência nem ao apreciador nem à coisa apreciada. A forma não determina a contemplação, pois não pode causá-la ou impô-la, dado que só se dá ao cabo de um processo de interpretação cujo aspecto ativo é evidente. Do mesmo modo, a interpretação não pode instaurar a contemplação a partir de si, visto que só pode fazê-lo no âmbito de um estímulo acolhido. O filósofo busca caracterizar a beleza a partir de uma compreensão que supere a oposição usual entre subjetividade ou objetividade do belo:

a beleza é peremptória somente para quem sabe vê-la, e, por outro lado, quem sabe ver a beleza a vê sempre em algo e como beleza de algo. Noutras palavras, por um lado a contemplação não é tanto um reconhecimento que se deve reduzir a mero registro sem caráter produtivo e figurativo, e, por outro lado, a contemplação não é tão produtiva a ponto de ser uma verdadeira e própria criação sem caráter de reconhecimento. ${ }^{253}$

Naturalmente, para além de sua dinâmica processual, a contemplação e a beleza supõem critérios para sua efetiva verificação. Recorde-se que a afirmação da personalidade da interpretação é de todo infensa a quaisquer veleidades relativistas. Assim, a possibilidade de um juízo acerca da beleza se esteia sobre "uma comparação interior da obra como é e da obra como queria e, logo, deveria ser". ${ }^{254}$ Assim, a beleza da obra se identifica com seu caráter de êxito, de adequação à própria lei. $\mathrm{O}$ belo se identifica com o bem-feito, com aquilo que se adequa à finalidade interna a que se dirigia. Daí a proeminência de que gozará a noção de forma formante também no processo interpretativo.

Se, no caso da arte, a absoluta individualidade e exclusividade de sua regra a torna um caso único, também no âmbito da formatividade em geral serão reencontradas interpretação, contemplação e beleza. O nexo necessário entre interpretação e contemplação de formas garante relevância estética a todo processo interpretativo, de qualquer natureza. As manifestações da formatividade,

\footnotetext{
${ }^{252}$ PAREYSON, L., Estética: teoria da formatividade, p. 188.

${ }^{253}$ PAREYSON, L., Estética: teoria da formatividade, p. 189.

${ }^{254}$ COPPOLINO, S. Estetica ed ermeneutica di Luigi Pareyson, p. 55.
} 
naturalmente, não denunciam um aspecto artístico somente quanto ao seu produzir-se, mas igualmente quanto à sua recepção: se, como afirma Pareyson, a realização de um valor qualquer não se pode dar sem a correspondente realização de um valor "artístico", a avaliação de toda obra permite sempre uma correspondente avaliação estética. $O$ belo assume assim um caráter de adequação finalística - com base nesta característica, afirma Morpurgo-Tagliabue que a estética de Pareyson se pode ler como "uma Crítica do Juízo lida ao revés, partindo do juízo teleológico. O belo se torna assim finalidade "interna", 255 de modo que se unificam perfeição e finalidade, belo e bem. Ou, segundo o próprio Pareyson, diante de processos realizados de modo exitoso, "chamamos belo àquilo que é 'bem feito': aquilo que é feito no modo requerido pela particular operação que se faz. Mais precisamente, belo é aquilo que realiza no caso determinado o conceito mesmo da operação que se vai fazendo". 256

Logo, a beleza não se restringe à esfera sensível - "a beleza de uma virtude, ou de uma ação, ou de um caráter, a perfeição de um raciocínio, a elegância de uma demonstração, a harmonia de um sistema de pensamento: eis tantos casos de beleza puramente intelectual, privada de qualquer elemento sensível”. ${ }^{257}$ Da vida moral à técnica, e nas várias "artes", sempre estão em jogo juízos estéticos e, na medida em que estes atentam àquele elemento formativo, não há distinção de natureza, antes de grau, entre os ajuizamentos que a formatividade suscita nesses casos, em comparação àqueles suscitados pela arte:

Quando se diz, por exemplo, que é bela uma ação, uma virtude, um caráter, ou um raciocínio, uma demonstração, um sistema filosófico, ou uma partida de futebol, uma faca, um automóvel, não se faz uma metáfora, mas se procede a uma verdadeira e própria avaliação estética. Trata-se de obras bem sucedidas no seu gênero que exigiram um exercício de formatividade e, por isso, revestem um

\footnotetext{
${ }^{255}$ MORPURGO-TAGLIABUE, G. Problemi attuali dell'estetica, p. 326. Esta questão ganha particular relevo adiante, ao se problematizar o lugar do belo natural no contexto da formatividade.

${ }^{256}$ PAREYSON, L., Problemi dell'estetica I. Teoria, p. 124.

${ }^{257}$ PAREYSON, L. Os problemas da estética, p. 153.
} 
caráter artístico, a ponto de que a avaliação estética coincide com a apreciação específica. $^{258}$

Esta onipresença de ajuizamentos genuinamente estéticos leva Ferraris a indicar em Pareyson uma "esteticidade difusa", e opor sua estética, sob este aspecto fundamental, àquela de Croce, com sua ênfase na insularidade e imediatidade do momento estético. É a oposição entre uma estética "sem obras" e uma estética centrada na obra:

A estética da expressão é por óbvia vocação uma estética da obra, aquela da formatividade uma estética sem obras; no primeiro caso, o processo formativo encontra, de qualquer modo, o próprio fim na expressão completada e imutável a partir daquele momento, a qual ilumina e confere valor, retrospectivamente, ao movimento do seu fazer-se; no segundo, ao invés, (...) é o termo ideal de um processo teleológico que é quanto se trata de indagar antes de tudo. A obra é em Pareyson antes um modelo no qual a formatividade se concentra, mas só para se prestar a um tratamento pelo qual todo o real deve ser indagado em analogia com aquilo que na constituição da obra se apresenta com particular evidência. ${ }^{259}$

Também Carchia salienta uma operação pareysoniana de "dessacralização" da arte, não mais "resgate catártico da impureza e do caos do mundo", concepção idolátrica ou fetichista que se depreendia da tradição neo-hegeliana com ênfase na autonomia artística. $^{260}$ A oposição entre Pareyson e Croce reedita aqui novamente segundo Ferraris - "aquela entre Hegel e Kant: no primeiro, uma estética que, apoiando o objetivo especificar-se e alienar-se da arte no mundo moderno, isola o momento discreto da obra, (...) no segundo, ao invés, a arte bela é ainda confundida no sistema das artes úteis". ${ }^{261}$ Reencontra-se no âmbito

${ }^{258}$ PAREYSON, L. Os problemas da estética, p. 32. Ressalte-se que segundo o autor, a "apreciação específica" é essencial, nesse caso, à apreciação estética que a pode acompanhar, de modo que a afirmação da esteticidade do todo da operabilidade humana vai de par com uma recusa do esteticismo: "o valor prático, ou teórico, ou econômico daquelas obras não me aparece se não me aparece também, aо mesmo tempo, o valor estético, e isto me aparece apenas no ato em que eu estou em condições de apreciar o primeiro". (ibidem, p. 32, grifos do autor). Recorde-se também a oposição que aqui se estabelece em face à doutrina crociana: nesta, em prol da autonomia da arte, a identificação de artístico e estético tornava mais problemática a passagem de uma fase do espírito à outra, tendendo a uma maior distância entre arte e vida (cf. CANEVA, C., Bellezza e persona, p. 57).

${ }^{259}$ FERRARIS, M., Un'estetica senza opere, p. 94.

${ }^{260}$ CARCHIA, G., Esperienza e metafisica dell'arte, p. 79.

${ }^{261}$ FERRARIS, M., Un'estetica senza opere, p. 94. 
interpretativo a mesma solidariedade entre a arte e a vida já acusada na dimensão formativa.

\section{2. \\ Interpretar a natureza}

Do ponto de vista da esteticidade difusa da experiência, e tendo por assentado que o exame da formatividade demonstrou a raiz desta esteticidade nos produtos da operatividade humana, surge consequentemente o problema da natureza, instância que está para além da operatividade pessoal. Se é possível afirmar coerente e univocamente a beleza de um utensílio, de uma estatueta, de uma pessoa ou de um filosofema, põe-se imediatamente a pergunta acerca da interpretabilidade da natureza, e de seu consequente potencial estético.

Embora reconheça a especificidade do problema artístico, Pareyson afirma a pertinência do tema do belo natural para a especulação filosófica, contra a tendência moderna, por ele assinalada, de demiti-lo da órbita das considerações estéticas. Nota o autor, que com a restrição do alcance da estética ao de uma pura e simples filosofia da arte, a própria formulação da questão do belo na natureza perde em importância, enquanto se salientam antes de tudo as diferenças entre as experiências do apreciador da arte e do amante de uma eventual beleza na natureza. $^{262}$

A especulação pareysoniana a esse respeito tem como seu pressuposto fundamental certa releitura da reflexão e da tradição estética kantiana. ${ }^{263}$ Por esta razão, de modo a melhor caracterizá-la, faz-se mister um retorno a esta leitura, na

\footnotetext{
${ }^{262}$ Cf. PAREYSON, L., Conversaciones de estética, p. 135.

${ }^{263}$ A centralidade que Pareyson atribui a Kant e à Crítica da Faculdade do Juízo na história da estética se deve ao fato de que nela, por um lado, culminam as estéticas iluministas, enquanto, por outro, dela partem as estéticas românticas, nas suas duas vertentes fundamentais: a "subjetivista", calcada numa interiorização da contemplação, com ênfase em seu aspecto de expressão sentimental da moralidade, como se vê em Schiller; e a "objetivista" (à qual se alinha), calcada na ênfase na natureza como objeto de contemplação estética e na aproximação que, pela genialidade, se estabelece entre natureza e produção artística, como se dá no pensamento de Goethe e Schelling. É o que o faz situar a terceira crítica como o "primeiro manifesto romântico" (ver PAREYSON, L., L'estetica dell'idealismo tedesco I. Kant e Schiller, pp.13, 158).
} 
qual, adicionalmente, se poderão captar alguns dos motivos inspiradores e subsídios teóricos cruciais para a teoria da formatividade.

\subsection{1.}

\section{Pareyson e Kant}

A abordagem de Pareyson, grandemente inspirada pela tradição romântica, concebe a estética de Kant como fundada, em última análise, mais na produção que na contemplação e, tendo assim, na arte (enquanto via de mediação entre natureza e razão, ou entre necessidade e liberdade) seu conceito fundamental. Uma unificação de arte e natureza sob a égide da produção, como a que Pareyson entrevê em Kant, põe em primeiro plano o problemático conceito de beleza aderente, como objeto de um juízo que enlaça os dois âmbitos da Crítica, ao admitir o juízo teleológico como fundamental para a esfera estética. ${ }^{264}$

Com efeito, Pareyson entende que "o que levou Kant a falar de juízo teleológico é exatamente a necessidade de ultrapassar a consideração mecanicista da natureza em uma consideração que, em lugar de conhecer teoricamente a natureza, buscasse interpretá-la" ${ }^{265}$ A discussão pareysoniana em torno ao conceito de beleza aderente, para além da importância capital a que o eleva na arquitetura da Crítica da Faculdade do Juízo, desempenha papel de relevo na sua concepção da beleza em geral e da beleza natural em particular, como se mostra a seguir. $^{266}$

\footnotetext{
${ }^{264}$ Cf. PAREYSON, L., Estetica dell'idealsimo tedesco I. Kant e Schiller, pp. 150-151.

${ }^{265}$ PAREYSON, L., Estetica dell'idealsimo tedesco I. Kant e Schiller, p. 141

${ }^{266}$ A leitura pareysoniana é, enquanto aproximação inescapavelmente pessoal que busca desvelar o sentido do texto kantiano, um exemplo eloquente de sua própria teoria da interpretação posta em prática (cf. RUSSO, F. Contemplazione e interpretazione, p. 105). Advirta-se, porém, que este estudo busca esclarecer as relações entre arte e natureza na estética de Pareyson e que, logo, sua leitura de Kant será abordada aqui somente enquanto fonte de "spunti" para seu desenvolvimento e de paralelismos que ajudem a esclarecer-lhe o sentido. Não se discutirá em nenhum momento a eventual adequação da mesma em relação a um pensamento "genuíno" de Kant. Daí a (quase) ausência de remissões à obra do filósofo alemão e de qualquer discussão de seu conteúdo tomado em si mesmo. Sendo a leitura pareysoniana da Crítica da Faculdade do Juízo focada nesta enquanto "abre o caminho à grande renovação romântica" (PAREYSON, L., Estetica dell'idealsimo tedesco I. Kant e Schiller, p. 11), o caráter problemático da leitura em questão, enquanto proposta de reconstrução doutrinal, já foi devidamente assinalado (para um breve elenco
} 


\subsubsection{1. Beleza aderente e juízo teleológico-estético}

Kant afirma que "a complacência no múltiplo em uma coisa, em referência ao fim interno que determina sua possibilidade, é uma complacência fundada sobre um conceito", 267 e que o juízo de gosto a ela referido não pode ser puro, mas “aderente". Pensar tal juízo, para Pareyson, supõe encontrar uma via de mediação entre as dimensões aparentemente contraditórias de uma finalidade objetiva como condição de "aderência" e de uma finalidade subjetiva (adequação ao livre jogo das faculdades do entendimento e da imaginação) como condição da contemplação pura, de modo que não somente coexistam, mas que a primeira seja uma efetiva condição indeclinável da segunda. ${ }^{268}$ Buscando esclarecer-lhe a possibilidade, Pareyson lhe conferirá, por fim, prioridade na especulação de Kant de modo a que o juízo do belo aderente "possa ser considerado como a satisfação da exigência mesma que levou o filósofo alemão a definir o conceito de beleza livre". 269

Pareyson discute, de início, as noções de beleza livre e aderente em sua relação com o binômio arte-natureza, mostrando a convertibilidade que as duas modalidades de beleza assumem face aos dois termos do binômio. É possível

de elementos díspares entre a leitura de Pareyson e a recepção tradicional da obra de Kant, em contexto bastante crítico àquela, ver, por exemplo, BROWN, M. E., On Luigi Pareyson's L'estetica di Kant: a review article, pp. 403-404; 409-410). No decorrer da análise de Pareyson, que objetiva liberar, em Kant, os elementos teóricos eventualmente constritos pelo pesado arcabouço sistemático, a ocasional recusa da "letra" em favor do "espírito" do texto, e desenvolvimentos relativamente autônomos a partir de questões controvertidas são procedimentos comuns. De modo que, em momentos - como no que toca à beleza aderente, por exemplo - a obra pode parecer mais propensa a uma interpretação $a$ posterius, a partir do ponto de vista romântico, e voltada a problemas então caros ao próprio Pareyson, do que a uma compreensão precisa da reflexão de Kant, fundada numa leitura rigorosa do ponto de vista histórico-filológico. (cf. RICCI SINDONI, P. Sul concetto di "bellezza aderente": Pareyson legge Kant, pp. 584, 595-596). Por naturais limitações de escopo, pois, opta-se aqui por restringir o foco à interpretação que Pareyson faz da obra de Kant, deixando em aberto a questão da fidelidade de uma à outra.

${ }^{267}$ KANT, I., Crítica da Faculdade do Juízo, p. 72.

${ }^{268}$ Cf. PAREYSON, L., Estetica dell'idealismo tedesco I. Kant e Schiller, p. 116.

${ }^{269}$ RICCI SINDONI, P. Sul concetto di "bellezza aderente": Pareyson legge Kant, p. 588. 
afirmar a liberdade do belo natural ou artístico, como também sua aderência. Assim, da perspectiva da técnica (produção), a natureza produziria belezas livres (pois sua técnica nos é vedada) e a arte belezas aderentes (pois como produção intencional, supõe um conceito); da perspectiva do juízo (recepção), dar-se-ia o oposto: a arte seria matriz de belezas livres (pois na bela arte o objeto poderia ser feito como privado de finalidade objetiva interna, de modo a suscitar a contemplação pura) e a natureza proveria belezas aderentes (dado que as coisas naturais permitem sempre a formulação de um juízo teleológico). No âmbito natural, assim, estaria dada a possibilidade de três tipos de juízo: o teleológico, o estético puro ou um "teleológico-estético". 270

$\mathrm{Na}$ natureza, antes que uma distinção entre coisas carentes de escopo interno e as que o possuíssem, haveria antes uma diferença de ponto de vista, segundo se atentasse ou não ao conceito em jogo em cada situação. No caso específico da beleza aderente, tratar-se-ia também de reavaliar os liames entre beleza e perfeição - em conformidade à tentativa kantiana de distinção de ambos os domínios - ao se supor um juízo do belo que se sustentasse sobre a perfeição, mas que também a ultrapassasse. Pareyson entende que na beleza livre, a finalidade formal termina por reduzir-se a uma finalidade objetiva enquanto posta à parte, desconsiderada ou ignorada. Se Kant tentara, pela afirmação da beleza livre, escapar ao "leibnizianismo", terminava por afirmá-lo inconscientemente, pois "a beleza livre é somente ignorância da perfeição e, pois, no fundo, percepção confusa desta". 271

$\mathrm{Na}$ medida em que a beleza aderente não é só perfeição, mas a engloba e inclui numa síntese ulterior, seria mais adequada a satisfazer as próprias exigências kantianas de base: nela, a contemplação surgiria de modo igualmente determinado e reconhecível, mesmo enquanto incluísse a perfeição. No entanto, dada a definição da beleza aderente, isto suporia uma distinção entre finalidade subjetiva (condição da contemplação) e finalidade formal. Deste modo, seria necessário um conceito (referência à perfeição da coisa) que não suprimisse o

\footnotetext{
${ }^{270}$ Cf. PAREYSON, L., Estetica dell'idealismo tedesco I. Kant e Schiller, pp. 122-124.

${ }^{271}$ Cf. PAREYSON, L., Estetica dell'idealismo tedesco I. Kant e Schiller, p. 126. O "leibnizianismo" em questão seria a tendência racionalista a pensar a beleza em termos de conhecimento "confuso" da perfeição de uma coisa.
} 
livre jogo das faculdades. Assim, finalidades subjetiva e objetiva poderiam pôr-se de acordo num mesmo juízo, pela inclusão do juízo teleológico no estético. ${ }^{272}$

Apelando à analogia com os objetos de arte, que são produzidos de modo a predispor-se ao livre jogo, pode-se aplicar tal visão à natureza se esta se interpreta como orientada finalisticamente às nossas faculdades, incluindo a finalidade subjetiva na objetiva por meio de um juízo teleológico. Dá-se uma mútua implicação e dependência entre juízo teleológico e estético: uma inclusão do juízo teleológico no estético, que se refere à contemplação da beleza; e uma inclusão do juízo estético no teleológico, que diz respeito à sua produção. ${ }^{273}$ Como resume Pareyson:

\begin{abstract}
na beleza aderente nos encontramos diante de uma inclusão do juízo teleológico no juízo estético, no sentido de que o juízo estético depende do reconhecimento de uma finalidade objetiva no objeto, e ao mesmo tempo, diante de uma inclusão do juízo estético no juízo teleológico, no sentido de que a possibilidade do juízo estético vem atribuída a uma intenção final da natureza em relação a nós. Ver a beleza natural em tal modo significa considerar a natureza como arte, não só enquanto se propõe um escopo objetivo interno ao objeto produzido, mas também enquanto se propõe como escopo o prazer no contemplante. ${ }^{274}$
\end{abstract}

\title{
3.2.1.2. \\ Ideias estéticas: produção e contemplação
}

A presença do conceito no juízo relativo à beleza aderente não deve comprometer a "liberdade" própria à contemplação estética (finalidade subjetiva). Pareyson sustenta que isto é possível se se atenta que na arte, como produção do gênio, o conceito que preside a operação não perturba a contemplabilidade, uma vez que a forma, conquanto referida ao conceito, não se reduz a uma sua exibição, mas nela a imaginação acolhe inúmeras representações, permitindo "pensar de um conceito muita coisa inexprimível”275 - como veiculação, enfim, de ideias estéticas.

Se a beleza natural livre também expressa ideias estéticas, conforme interpreta em Kant, Pareyson julga que com igual razão deve fazê-lo a beleza aderente. Nesta, a forma na intuição, para além da mera exibição de um conceito

\footnotetext{
${ }^{272}$ Cf. PAREYSON, L., Estetica dell'idealismo tedesco I. Kant e Schiller, p. 128.

${ }^{273}$ Cf. PAREYSON, L., Estetica dell'idealismo tedesco I. Kant e Schiller, p. 132.

274 .PAREYSON, L., Estetica dell'idealismo tedesco I. Kant e Schiller, pp. 130-131.

${ }^{275}$ KANT, I., Crítica da Faculdade do Juízo, p. 174.
} 
determinado, incluiria uma infinidade de representações. Assim como, na produção artística, o conceito é ocasião para ideias estéticas, e a imaginação coliga-se à razão sem deixar de estar associada ao entendimento, na apreensão da bela coisa natural a mera adequação desta a seu conceito seria ultrapassada por seu caráter exibidor de ideias estéticas: “a beleza aderente é aderente porque a forma final do objeto é adequada a seu escopo interno, e é beleza porque a forma final do objeto se adequa ao mesmo tempo ao mundo suprassensível. Tem-se assim uma espécie de juízo teleológico aberto". ${ }^{276}$ Logo, a junção de imaginação e razão presente no gênio será também encontrável no gosto, sendo comum quer à produção da arte, quer à contemplação da natureza. A doutrina do gênio como faculdade produtiva na arte, segundo Pareyson, é pressuposto para a correta compreensão da doutrina do gosto, sugerindo-se inclusive uma identificação, com diferença apenas de ênfase, entre as duas faculdades, com a consequente aproximação dos momentos da produção e da contemplação. ${ }^{277}$

\subsubsection{3. \\ Natureza como produtividade orgânica}

Pareyson julga que a recusa kantiana do naturalismo - imposta por seu criticismo - impede-o de unir juízo teleológico e estético de modo que o primeiro seja efetivamente condição e motivo do segundo, avanço que a seu ver a tradição romântica, a partir das sugestões kantianas, realizou. Isto se deu (indo além de Kant) a partir da ênfase numa finalidade da natureza, votada a seus próprios fins os organismos - enquanto estes são, por si mesmos, contempláveis. Aí, o juízo teleológico afastado tanto do interesse quanto do empenho cognitivo conceitual, se converte verdadeiramente numa interpretação da natureza que colhe-a em sua ulterior contemplabilidade. Suprime-se igualmente a distinção entre beleza livre e beleza aderente, dado que "a indeterminação do conceito do entendimento necessária à beleza livre não é outra que a necessária indeterminação do entendimento inerente a uma ideia da razão", 278 a qual se manifesta, por exemplo, no juízo teleológico, de modo que "toda beleza é sempre livre e aderente: livre

\footnotetext{
${ }^{276}$ PAREYSON, L., Estetica dell'idealismo tedesco I. Kant e Schiller, p. 136.

${ }^{277}$ Cf. PAREYSON, L., Estetica dell'idealismo tedesco I. Kant e Schiller, pp. 133-135.

${ }^{278}$ PAREYSON, L., Estetica dell'idealismo tedesco I. Kant e Schiller, p. 142.
} 
porque não adere a um conhecimento conceitual, aderente porque adere a uma interpretação da natureza". ${ }^{279}$ É só a partir de tal leitura que se pode efetivamente fazer, segundo Pareyson, justiça à noção de beleza aderente. $\mathrm{O}$ suprassensível se apresenta no reconhecimento do escopo da coisa e redunda numa sua avaliação estética.

Tem-se aqui, também, um elo entre arte e natureza e entre produção e contemplação, que se funda sobre a possibilidade mesma da beleza aderente. A arte bela não pode ser apreciada sob a égide de uma finalidade real, mas ideal, segundo Kant, no que se assemelha ao modo como a natureza se mostra quando é vista como bela, como contingente em sua adequação a nossas faculdades cognitivas. Mas a adequação entre objeto e conhecimento, mesmo em sua idealidade, aponta para um substrato suprassensível dos fenômenos que fundamenta a ambos. Por seu turno, na arte é o gênio, enquanto natureza, que deve lhe dar regras, e é o gênio, enquanto faculdade de ideias estéticas, que permite "exibir" ideias racionais. Se o gênio pode, para além da razão teorética e prática, tornar sensível o suprassensível, isto se dá porque nele se unem natureza e razão, natureza objetiva e natureza do sujeito sensível e suprassensível.

A arte bela aparece, pois, como um misto de intencionalidade e contingência, mas assim também a natureza: se esta é bela quando se mostra com aparência de arte, é porque se parece com a arte no que esta tem de intencionalidade que não busca fins determináveis previamente. Correlativamente, a arte se mostra com aparência de natureza quando se mostra - como esta - na contingência "casual" de seu acordo com nossa faculdade cognitiva:

Na beleza coincidem, em suma, natureza e arte, no sentido que a arte mecânica, conservando a única intencionalidade compatível com a contingência da natureza, se faz arte bela, e a natureza, conservando a única contingência compatível com a intencionalidade da arte, se faz natureza bela: a intencionalidade da arte humana se tempera com a contingência natural, a contingência da natureza como organismo se funde com a intencionalidade da arte humana. ${ }^{280}$

Ver a coisa como contingência e gratuidade é vê-la na sua autonomia e autossuficiência, na sua simples presença; vê-la como intencionalidade é vê-la como um resultado, como fruto de um processo. A este conúbio de

\footnotetext{
${ }^{279}$ PAREYSON, L., Estetica dell'idealismo tedesco I. Kant e Schiller, p. 142.

${ }^{280}$ PAREYSON, L., Estetica dell'idealismo tedesco I. Kant e Schiller, p. 149.
} 
intencionalidade e contingência, encontrável na arte e na natureza Pareyson chama espontaneidade - e esta, enquanto não é deliberação, e tampouco é arbitrariedade, constitui-se num "proceder ao acaso que é ao mesmo tempo buscar; inventar que emerge de um tentar, e tentar em vista de um inventar". ${ }^{281}$

\subsection{2.}

\section{O belo natural na teoria da formatividade}

A teoria da formatividade afirma categoricamente - em oposição polêmica à filosofia do espírito - a realidade do belo natural. Conforme aponta Ciglia, um encaminhamento desta afirmação já se anuncia, em Pareyson, a partir da decidida revalorização da matéria na arte, como base natural da produção que, longe de ser substrato bruto e inerte, é sempre já prenhe de sugestões e possibilidades artísticas, convidando à interpretação formativa. ${ }^{282}$ De modo mais específico, no entanto, a questão admite os seguintes contornos: dado o caráter de resultado inerente a toda forma, à produtividade humana manifestada nas formas artificiais parece dever-se aliar uma produtividade da natureza, se se supõe em seus "produtos" a possibilidade de contemplação. Deve-se perquirir, por um lado, em que sentido se pode afirmar uma produtividade na natureza - exigida pelo seu caráter contemplável - e, por outro, abordar a questão sobre "se a produção, da qual o belo natural é resultado, seja anterior à contemplação que dela se faz, ou se reduza à produtividade mesma de tal contemplação, ou de algum modo se encontre com esta e nela se prolongue". ${ }^{283}$

A possibilidade do belo natural repousa sobre o caráter interpretativo do conhecimento sensível, o qual permite, como visto, que se alcance, por via de um processo formativo, a consideração da forma enquanto forma, e logo, como dotada de contemplabilidade. $O$ belo natural não será senão o caráter contemplável da forma haurida de uma interpretação da coisa em questão, o "grau

\footnotetext{
${ }^{281}$ PAREYSON, L., Estetica dell'idealismo tedesco I. Kant e Schiller, p. 149.

${ }^{282}$ Cf. CIGLIA, F. P., Ermeneutica e libertà, p. 139.

${ }^{283}$ PAREYSON, L., Problemi dell'estetica I. Teoria, p. 114.
} 
de perfeição que possui a imagem que se obteve ao contemplá-la e interpretála". ${ }^{284}$ E prossegue Pareyson,

conhecer as coisas, e conhecê-las verdadeiramente, isto é, não esboçar delas lábeis esquemas, mas delas figurar imagens que as captem plenamente, significa ver as coisas como formas, isto é contemplar-lhes a beleza, de modo que há sempre um momento no qual o conhecimento da natureza se deixa absorver numa contemplação do belo. ${ }^{285}$

A experiência do belo natural implica que se suspenda a consideração utilitária das coisas. Muito embora algum esforço interpretativo se faça necessário mesmo para que se dê a utilização de uma coisa - dado que esta nunca é por si um utensílio, mas deve ser constituída como tal numa apropriação interpretativa - este esforço tende a restringir-se ao mínimo requerido para consecução de seu escopo, àqueles aspectos diretamente ligados à realização do mesmo, não abrindo, assim, suficiente espaço à contemplação. Para que se experimente a beleza, tal consideração apressada deve dar lugar ao demorado perscrutar, movido a um só tempo por interesse e respeito, abandonando as próprias finalidades de modo a deixar a coisa mostrar-se apenas enquanto realidade formal. De capital importância aqui é a distinção entre uma finalidade externa à forma, inerente a todo uso, e uma finalidade puramente interna à qual a contemplação se deve dirigir. $^{286}$

Como com os objetos dos empenhos formativos e produtivos humanos, o belo natural se radica igualmente no encontro entre um esforço figurador e uma solicitação ou sugestão de forma (e assim, também aí as categorias estanques de subjetividade e objetividade se mostram incapazes explicá-lo). ${ }^{287}$ Este encontro se deve dar, adverte o filósofo, tendo por paradigma o modo como se procura conhecer as pessoas, atividade que se mostra, dada a mobilidade multifacetada que as caracteriza, sempre dificultosa. Nesse sentido, a interpretação devotada do mundo natural exige uma sua relativa "personalização":

Ora, o conhecimento das coisas também implica esse conhecimento que é necessário na interpretação das pessoas. Para conhecer as coisas, devo interrogá-

\footnotetext{
${ }^{284}$ PAREYSON, L., Conversaciones de estética, p. 136.

${ }^{285}$ PAREYSON, L., Problemi dell'estetica I. Teoria, p. 117.

${ }^{286}$ Cf. PAREYSON, L., Estética: teoria da formatividade, pp. 204-206.

${ }^{287}$ Cf. PAREYSON, L., Estética: teoria da formatividade, p. 199.
} 
las, mantê-las em uma certa independência própria e na sua originalidade, como se fossem "pessoais" (...) Como não é possível conhecer as pessoas se estas se reduzem a mero objeto ou integração necessária de nossa individualidade, da mesma forma não é possível conhecer as coisas a não ser personificando-as, vendo-as em sua animada e original independência (...) quem não sabe interpretar as coisas como "pessoas" se põe em uma atitude que leva inconscientemente a considerar igualmente as pessoas como "coisas". ${ }^{288}$

Do belo natural como fruto de uma interpretação da natureza depreende-se igualmente, portanto, o elo entre as dimensões ética, estética e noética. Se o belo supõe um esforço de interpretação, este supõe profundos respeito e fidelidade pelo interpretado, nunca a prepotente sobreposição de nossos interesses sobre aquele. Como afirma o filósofo, interpretar a natureza implica amá-la, de modo que, para além da apreciação estética, esta reflexão aponta igualmente para uma dimensão "ecológica", enquanto alerta que se a "interpretação se desvincula da fidelidade, torna-se convite ou caminho aberto à violação". ${ }^{289}$ A natureza deve ser abordada em seu caráter de transcendência e autonomia, com o que se nos mostra amável, interpretável e contemplável.

Se a consideração formal das coisas naturais não é mera imposição de um sujeito, mas um efetivo diálogo com uma pessoa, forçoso é reconhecer que as coisas naturais são formas. Como esclarece o filósofo, isto decorre da própria estrutura da interpretação como visão e produção formativas. Se se requer um determinado olhar de modo a captar a coisa como forma, é só porque a própria coisa igualmente o admite. $\mathrm{O}$ esforço formativo se divide entre natureza e ímpeto cognoscitivo, e de nossa possibilidade de conhecer a natureza se passa a uma

\footnotetext{
${ }^{288}$ PAREYSON, L., Estética: teoria da formatividade, pp. 200-201.

${ }^{289}$ PAREYSON, L., La natura tra estetica e ontologia, p. 13. Com efeito, Pareyson reconhecerá limitações também ao olhar "ecológico", na medida em que, por um lado, aferrar-se-ia a uma afirmação preconceituosa e idílica da "bondade primitiva" da natureza, ignorando o quanto de desordem e destruição se acolhe em seu seio; e por outro, terminaria por supor um cálculo de vantagens, supondo a maior utilidade relativa de sua preservação, e ignorando a dimensão do respeito à mesma em sua própria autonomia, e em última instância, como criação sobre a qual se detém responsabilidade, mas não posse e domínio absolutos. Tais concepções (que devem ser compreendidas no quadro das preocupações do último Pareyson, voltadas às relações entre a natureza e o mal no contexto de uma "ontologia da liberdade" humana e divina) não serão aprofundadas aqui, mas somente registradas, uma vez que se afastam da consideração especificamente estética à qual aqui se visa (para mais detalhes sobre estas considerações cf. ibidem, pp. 14, 16 et seq.).
} 
afirmação de sua produtividade. Dito de outro modo: ao interpretar (formativamente) a natureza, esta se mostra igualmente como formatividade, pois se não provesse formas, não a poderíamos conhecer. Donde Pareyson concluir que, diante da natureza

nosso conhecimento não seria capaz de figuração e formatividade, não seria, nesses termos, interpretação, se a natureza não formasse e figurasse por sua vez, e justamente porque a natureza possui poder formante, o conhecimento que dela possuímos tem caráter formativo. O nosso conhecimento das coisas não culminaria em uma visão de formas se as próprias já não fossem formas, ou seja, objetos de interpretação e só de interpretação. ${ }^{290}$

Nestes termos, entende-se como "a contemplação do belo natural pressupõe que a natureza possua um poder formante". ${ }^{291} \mathrm{O}$ conhecimento das coisas naturais (e daí sua beleza) só é possível com base numa solidariedade originária entre pessoa e natureza. Esta solidariedade, porém, não se afirma imediatamente, sem uma adequada justificativa ou como uma mera comparação sem relevância teorética. Antes é reconhecida e afirmada por via interpretativa, segundo o esquema seguinte: se o homem só conhece formas e só as conhece interpretando; e se pode conhecer (e mesmo fruir, sob aspecto unicamente formal) a natureza, decorre daí que a natureza tenha realidade de forma, que se constitua de formas. Estas formas, por fim, devem supor uma formatividade natural que as origina; e a interpretação, assim, em seu esforço produtivo, prolonga e testifica a própria produtividade natural, a qual não obstante, só se dá a conhecer no seio desta mesma interpretação. ${ }^{292}$

Aqui encontra-se, afinal, sob um prisma gnoseológico, a fundamentação daquele nisus formativus da natureza, o qual se afirma como paradigma e modelo à produtividade humana, segundo a visão da arte como imitação da natureza. A defesa teorética deste poder formante não se realiza, no entanto, como uma asserção abstratamente metafísica, como se se a pudesse fazer do ponto de vista da própria natureza. Antes surge de uma exigência do conhecimento humano em sua necessária condição de autorrelação e heterorrelação, de atividade e receptividade. Ao mesmo tempo, se impõe em sua validade, de modo que, uma

\footnotetext{
${ }^{290}$ PAREYSON, L., Estética: teoria da formatividade, p. 210.

${ }^{291}$ PAREYSON, L., Estética: teoria da formatividade, p. 210 (grifo meu).

${ }^{292}$ Cf. PAREYSON, L., Estética: teoria da formatividade, p. 210.
} 
vez estabelecida a realidade da beleza natural, esta não pode senão nos permitir um vislumbre, "uma olhada clarificadora, como um golpe de sonda, nas profundidades metafísicas da natureza". ${ }^{293}$

Uma vez afirmado o belo na natureza, completa-se a peculiar e abrangente visão estética pareysoniana, que, pode-se dizer, se esteia sobre uma "formatividade universal": nela se congregam a beleza produzida pelo homem, seja estética (geral) ou artística (particular) e o belo na natureza. Logo, toda a realidade, enquanto constituída de formas, é necessariamente perpassada pela dimensão estético-formativa. ${ }^{294}$ Belo natural e belo artístico-estético respondem a um mesmo esforço interpretativo, que neles alcança uma mesma realidade formal.

\section{3. Metafísica da figuração: unificação estética de natureza e arte}

Uma questão que necessariamente se impõe, neste contexto, é aquela acerca do fundamento último desta solidariedade entre arte e natureza. Como sugere Blanco Sarto, "toda 'física ou biologia da arte' necessita de uma certa 'metafísica", mesmo que disso não decorra necessariamente "abandonar a experiência concreta e elaborar um rígido sistema baseado em princípios e definições". ${ }^{295}$ Com efeito, Pareyson, já em Estética: teoria da formatividade, admite que a estrutura do realizar pode "permitir que se lance um olhar ao segredo originário da realidade universal, com o qual a estética se estende inevitavelmente até a metafísica". ${ }^{296} \mathrm{E}$

293 PAREYSON, L., Conversaciones de estética, p. 137.

${ }^{294}$ Cf. MURA, A. La concezione estetica in Luigi Pareyson, p. 18. É útil recordar aqui a ênfase da definição pareysoniana da estética como "filosofia inteira enquanto empenhada em refletir sobre os problemas da beleza e da arte" (PAREYSON, L., Os problemas da estética, p. 4, grifos nossos). $\mathrm{Na}$ medida em que formatividade, formas e contemplabilidade caminham juntas, a beleza goza, na estética em questão, de relevo equivalente ao da arte e, pelo liame que as une, se configuram ambas em objeto da estética. Arte e beleza se irmanam enquanto, conforme sintetiza Vecchi, “o belo é o êxito do conhecer, a arte é o êxito do produzir" (VECCHI, G., L'estetica della formatività di Luigi Pareyson, p. 357). Por outro lado, é pela ausência mesma de tal elo que Pareyson nega que a Antiguidade possua uma estética, e o que o leva a criticar as tentativas de separar os dois domínios em ramos da estética contemporânea (cf. PAREYSON, L., Os problemas da estética, p. 1; ver também PAREYSON, L., Problemi dell'estetica I. Teoria, pp. 139-140).

${ }^{295}$ BLANCO SARTO, P., Hacer arte, interpretar el arte, p. 256.

${ }^{296}$ PAREYSON, L., Estética: teoria da formatividade, p. 266. 
no entanto, a questão desta base metafísica assumirá um caráter singular, e passará por profundas transformações em razão do direcionamento teórico posterior do filósofo.

É a partir das exigências da aceitação de um formar da natureza que começam a desenhar-se, segundo Ciglia, os contornos de uma "metafísica da figuração", de inserção assaz problemática no interior da teoria da formatividade. ${ }^{297}$ Este desdobramento, relevante para a compreensão da possibilidade mesma de uma tal estética, se mostra particularmente importante no que toca ao problema da natureza, tal como aponta Eco ao afirmar que a estética contemporânea, via-de-regra infensa a fundamentar suas experiências de base em postulados metafísicos ou apriorísticos, pode

\begin{abstract}
descrever processos formativos e processos interpretativos, as formas e as "leituras" que delas se podem fazer, antes de dizer o que quer que seja sobre o mundo, visto como fundo geral desta atividade. Naturalmente que, no ponto crucial em que a atividade interpretativa pessoal se encontra com um ponto de partida [spunto] que já não é obra humana mas dado natural, esta análise acha-se perante problemas do tipo "metafísico" (...) Mas logo que o discurso volta à interpretação de uma forma resultante de um ato humano, o problema simplifica-se, visto que o "figurador" humano postulado pela experiência das formas artísticas já não é uma ideia metafisica, mas um dado empiricamente documentável. ${ }^{298}$
\end{abstract}

Para Pareyson, a possibilidade de solidariedade estética entre arte e natureza supõe uma articulação entre formatividade e interpretação, assim como uma mediação entre o que o filósofo chama de estéticas da perfeição e estéticas da expressão, e seus antagônicos pressupostos metafísicos. Trata-se, em suma, de averiguar que tipo de concepção metafísica de base é compatível com a teoria da formatividade.

\title{
3.3.1.
}

\section{A forma: síntese de contemplação e produção}

Segundo Pareyson, uma "estética da perfeição" afirma na beleza a exemplaridade e a normatividade, e supõe uma visão metafísica que afirme a realidade como perfeita e acabada e, pois, incapaz de admitir inovações ao mesmo tempo em que se afirma como paradigma para imitação, à qual reduzir-se ia todo esforço

\footnotetext{
${ }^{297}$ Cf. CIGLIA, F. P., Ermeneutica e libertà, pp. 139-140.

${ }^{298}$ ECO, U. A definição da arte, p. 26 (grifo do autor).
} 
produtivo. Assim, tal estética funda filosoficamente a contemplação, mas não a produção da beleza na arte, que seria mero rebaixamento e cópia, sem traço expressivo. Implica uma concepção da contemplação como passividade, simples registro e não mais encontro, correspondência efetiva. De capital importância aqui, uma metafísica da realidade acabada justifica o belo natural, quando menos na condição de reflexo da beleza ideal.

Uma "estética da expressão", por sua vez, afirma na beleza o caráter expressivo e singular, sob a égide da produtividade. Supõe uma metafísica que afirme a realidade como contínua inovação e criação. Se toda criação é absoluta, a própria contemplação se reduz à criatividade, devendo a cada vez refazer a obra. Funda-se filosoficamente a produção da arte como efetiva criação, mas rejeita-se a contemplabilidade à natureza. Arte ou natureza se veem rebaixadas segundo cada modelo, que, além disso, mostrar-se-ia contraditório se levado a suas últimas consequências. Uma produção privada de contemplação - que não produz um contemplável - se diluiria na pura criatividade espiritual, comprometendo sua singularidade; ao mesmo tempo, uma contemplabilidade que recusasse a produção redundaria em mera representação ou cópia, e sua exemplaridade seria inerte e vã. Se só há contemplação, não resta espaço à produção, e vice-versa. ${ }^{299}$

A afirmação conjunta do potencial estético na arte e na natureza requer, segundo Pareyson, uma mediação sob o conceito de forma, que é manifestação conjunta e simultânea de contemplação e produção e que permite àquela ser ao mesmo tempo singular e exemplar - tal é exatamente o escopo de uma estética da formatividade: na forma

devem coincidir perfeição e expressão: por um lado, esta é um organismo perfeito e, por outro, é um reflexo da personalidade do artista. A estética da formatividade pretende conciliar assim produção e contemplação, arte e natureza, originalidade e imitação, fazer e expressar. ${ }^{300}$

Contemplação e produção se harmonizam porque o produzir da forma e o interpretar da mesma são formativos: "a contemplabilidade é resultado e

\footnotetext{
${ }^{299}$ Cf. PAREYSON, L., Problemi dell'estetica I. Teoria, pp. 110-112.

${ }^{300}$ BLANCO SARTO, P. Hacer arte, interpretar el arte, p. 258.
} 
pressuposto da produção porque produção é tanto aquela que dá lugar à forma contemplável quanto aquela que culmina na contemplação que dela se faz". 301

Uma estética da forma, na qual formatividade (produção) e interpretação (recepção) se implicam mutuamente, supõe uma "metafísica da figuração" que admita a realidade como passível de inovação, bem como uma inter-relação das formas. Como nota Ferraris:

Aqui permanece válido o modelo da relação kantiana entre finalidade subjetiva e finalidade objetiva, só que Pareyson dá um passo adiante, e não exclui aquilo que Kant havia rejeitado por razões de coerência com o assunto crítico, ou seja, a possibilidade de uma metafísica da forma que una originariamente a formatividade humana em toda sua especificação e a formatividade natural. ${ }^{302}$

Somente ela permitiria, por conseguinte, uma coexistência efetiva, e a igual título, do belo na arte e na natureza. ${ }^{303}$ Isto porque somente a partir de tal pressuposição se poderia garantir às formas naturais a consistência ontológica que lhes permitiria ser objetos de interpretações fundamentadas - "não um universo casual que só pode ser ordenado a partir da proposta interpretativa do homem, mas que tem já em si possibilidades precisas de ordem". 304

\subsection{2.}

\section{Natureza e metafísica: o "Figurador"}

A possibilidade da arte como realização individual, incremento de realidade, patenteia para Pareyson o caráter de totalidade e universalidade do finito, que não pode, por isso, ser reduzido jamais a uma parte ou momento do todo. Fiel a seu existencialismo, o autor uma vez mais exalta a riqueza do indivíduo, com a inexaurível infinitude que este acolhe em si. Enquanto a pessoa parece repetir, em seu operar, o esforço de singularização que perpassa o real, a especulação estética acena inevitavelmente à especulação metafísica: "se o segredo da realidade é a individuação, seja lá como se conceba, a arte, que é essencialmente realização e

\footnotetext{
${ }^{301}$ PAREYSON, L., Problemi dell'estetica I. Teoria, p. 112.

${ }^{302}$ FERRARIS, M. Un'estetica senza opere, p. 96.

${ }^{303}$ Cf. PAREYSON, L., Problemi dell'estetica I. Teoria, p. 112.

${ }^{304}$ ECO, U., A definição da arte, p. 25
} 
singularização, simboliza e de certo modo continua esse ato que está na origem dos seres e das pessoas, e se insere em um horizonte cósmico", 305

Considerações como a reproduzida acima levam Eco, por exemplo, a sustentar que a estética da formatividade supõe "a presença de um Figurador que constitui as formas naturais inteiramente como pontos de partida [spunti] de interpretações possíveis, não pontos de partida amorfos e casuais, mas densos de intenção". ${ }^{306}$ A ideia de uma fundação metafísica que desse conta da realidade do spunto encontra respaldo em Pareyson quando este afirma que

uma estética da forma reenvia a uma gnoseologia da interpretação, e uma gnoseologia da interpretação reenvia a uma metafisica da figuração. Não insisto sobre os muitos argumentos que existem para demonstrar que uma metafisica da figuração reenvia, por sua vez, a uma metafísica da criação. ${ }^{307}$

Deve-se salientar, no entanto, que este discurso encontra bastantes ressalvas e limitações na teorização pareysoniana. O próprio Eco o aponta ao reconhecer que este Figurador é antes postulado que demonstrado a partir da existência de figurações e figuradores singulares, e que o horizonte que aí se tem em vista está distante de um fechamento unívoco e objetivante, tal como se esperaria de uma metafísica do ser ou das essências. ${ }^{308}$ Além disso, recorde-se que tal "metafísica da criação" não foi jamais efetivamente formulada por Pareyson. ${ }^{309}$ Por outro lado, se se afirma efetivamente o caráter de "co-criação" da arte humana face à criatividade divina, enquanto aquela continua um poder formativo da natureza, está-se aqui diante de uma metafísica "indireta", mais que de um realismo apriorístico de matiz "clássico". ${ }^{310}$ Se esta solidariedade operativa é em alguma medida afirmada pela teoria, o próprio filósofo reconhece as restrições inerentes a qualquer discurso deste jaez:

Muitas vezes se falou da excelência do artista, como aquele que repete no seu mundo o mistério da criação, a ponto de merecer o epíteto "divino" e vice-versa, houve quem visse em Deus o supremo "Artista" do universo. Mas a definição dessas analogias precisa ser acompanhada de tais e tantas limitações e

\footnotetext{
${ }^{305}$ PAREYSON, L., Estética: teoria da formatividade, p. 266.

${ }^{306}$ ECO, U., A definição da arte, p. 24.

${ }^{307}$ PAREYSON, L., Problemi dell'estetica I. Teoria, p. 118.

${ }^{308}$ Cf. ECO, U., A definição da arte, pp. 24-26.

${ }^{309}$ Cf. CIGLIA, F. P., Ermeneutica e libertà, p. 140.

${ }^{310}$ Cf. BLANCO SARTO, P. Hacer arte, interpretar el arte, p. 259.
} 
especificações, que as comparações estabelecidas tendem a perder o seu caráter intencionalmente "revelador" para conservar quando muito um alcance de "sugestão". E isso pede que se veja nessas teorias mais a definição de um particular "ideal" da arte que propriamente uma via de acesso aos segredos da natureza e de Deus. ${ }^{311}$

Esta passagem, de seu opus magnum de estética, mostra-se consequente à ênfase que o autor dará, numa obra posterior, às inevitáveis limitações inerentes ao pensamento humano em sua relação com a verdade. Sendo esta, a seu ver, inobjetivável, e sendo o pensamento expressão de sua situação e contexto particular mesmo quando seja também revelação da verdade, dá-se que a verdade só se pode colher a partir de uma formulação pessoal e histórica, nunca numa hipotética determinação autônoma. No entender de Pareyson, a verdade nunca pode ser vista "de fora" ou "em si", nem é possível assim jamais cotejá-la com a formulação, única via de acesso a ela. Assim, defenderá em termos decididos “o fim da metafísica ôntica e objetiva e a sua substituição por uma metafísica ontológica e indireta, que é hoje, o único modo de preservar o caráter universal e especulativo da filosofia e, portanto, de assegurar a sobrevivência da metafisica". ${ }^{312}$ No quadro desta orientação ulterior, a própria ideia de uma metafísica da figuração é objeto de uma revisão.

\subsection{3. \\ Metafísica da figuração e a "virada ontológica"}

A ambiguidade que marca a inserção da metafísica da figuração na estética da formatividade se confirma por um documento bastante posterior à sua formulação, a saber, uma carta de Pareyson datada de 1976, na qual responde criticamente à interpretação que lhe era dedicada numa obra de síntese sobre a estética italiana. O autor de dita obra apontava uma tensão não resolvida, na estética de Pareyson, entre uma fenomenologia da atuação humana e a fundamentação metafísica desta, ou entre fenomenologia e ontologia. ${ }^{313}$ Pareyson revisita o tema com os seguintes esclarecimentos:

\footnotetext{
${ }^{311}$ PAREYSON, L., Estética: teoria da formatividade, p. 266.

${ }^{312}$ PAREYSON, L., Verdade e interpretação, p. 111.

${ }^{313}$ A obra referida é Situazione dell'estetica in Italia, Paravia, Torino, 1976, de Lino Rossi. A carta de Pareyson em questão, endereçada a Luciano Anceschi, é reproduzida, num apêndice, ao fim do estudo de Ciglia (cf. CIGLIA, F. P. Ermeneutica e libertà, pp. 316-318).
} 
$\mathrm{Na}$ minha estética busquei fazer uma fenomenologia, ou, como eu prefiro dizer, uma "análise da experiência", e desafio quem quer que seja a ali encontrar uma "fundamentação metafísica" ou uma alusão que seja verdadeiramente metafísica: a única expressão que me escapou dizer, a respeito, foi a famigerada "metafísica da figuração", que depois releguei (não por acaso, e é bom método relevar estas verdadeiras e próprias "correções" que qualquer pensador vai gradualmente fazendo) às "Discussões" de Teoria dell'arte. ${ }^{314}$

Ainda que se reconheça, acompanhando Ciglia, a progressiva perda de espaço - ou mesmo o repúdio - da metafísica da figuração no interior da especulação pareysoniana ulterior, ${ }^{315}$ resta a questão acerca do peso relativo que estes elementos "metafísicos" desempenham para a compreensibilidade e aplicabilidade da teoria, particularmente como fundamentação da possibilidade conjunta de belo artístico e natural. ${ }^{316}$ É o mesmo comentador que, atentando ao

${ }^{314}$ PAREYSON, L. apud CIGLIA, F. P. Ermeneutica e libertà, p. 316. O brevíssimo texto no qual Pareyson expõe as linhas gerais da metafísica da figuração, intitulado "Estetica e metafisica", de 1950, constava da primeira edição de Estetica: teoria della formatività, mas foi suprimido a partir das seguintes, vindo a ser inserido na seção intitulada "Discussões" da obra Teoria dell'arte. O texto em questão, quando citado aqui, o é a partir de sua reedição nas Obras Completas (cf. PAREYSON, L., Problemi dell'estetica I. Teoria, pp. 110-113). Blanco Sarto interpreta esta retirada do texto daquela que é a mais sistemática exposição da estética de Pareyson como sinal de que "ainda que a ontologia se encontre implicitamente na base da 'estética da formatividade', nosso autor prefere não desenvolver reflexões explicitamente metafísicas" (BLANCO SARTO, P., Hacer arte, interpretar el arte, pp. 256-257).

${ }^{315}$ Cf. CIGLIA, F. P. Ermeneutica e libertà, p. 180.

${ }^{316}$ Eco, por exemplo, defende a possibilidade de manter-se, perante a estética da formatividade, em nível estritamente "fenomenológico", restringindo-se à sua descrição dos processos formativos no contexto das relações humanas intersubjetivas, e desconsiderando as pressuposições metafísicas admitidas por Pareyson (e admitidas, a seu ver, somente num plano ulterior de sua reflexão). Outra possibilidade seria a de retornar à esfera metafísica não mais como pressuposto, mas como sugestão a partir da realidade mesma da interpretação das formas da arte. A teoria de Pareyson seria assim aplicável e utilizável enquanto descrição de uma atividade, mesmo a partir de uma recusa prévia de fundamentações metafísicas possíveis desta atividade (cf. ECO, U., A definição da arte, p. 27). É útil recordar que a teoria da formatividade chegou, por outro lado, a admitir leituras francamente metafísicas, de cariz neoescolástico, embora mesmo numa tal leitura se reconheça a ausência de uma fundamentação metafísica explícita e acabada nos escritos de Pareyson. Exemplo de uma leitura deste tipo é a interpretação proposta por Antonio Mura (cf. MURA, A., La concezione estetica in Luigi Pareyson, pp. 73-77). Não por acaso, nesta obra se concede considerável ênfase à formatividade natural. 
posterior aprofundamento da perspectiva ontológica no pensamento de Pareyson, reencontra ecos da "metafísica da figuração" na reformulação relativa por que passa a noção de situação entendida como apelo à liberdade e perspectiva sobre o ser. Apoia-se, para tanto, na ênfase positiva que Pareyson dá à "situação" própria ao artista, seja nos aspectos sociais, culturais e históricos desta, seja em seus aspectos - mais importantes aqui - físicos e naturais, os quais nunca se põem como meros obstáculos. Recorda que, buscando um ponto igualmente distante das estéticas da criação ou da imitação - entendidas cada qual unilateralmente -, Pareyson tentava com a metafísica da figuração não "reduzir os condicionamentos mais especificamente materiais e naturais do processo de formação estética a pura e simples resistência a vencer ou a pura e simples negatividade". ${ }^{317}$ Assim, julga que os elementos da metafísica da figuração tornam a aparecer, transmutados, na renovada compreensão da situação não mais como fundo informe a ser resgatado e elaborado pela iniciativa pessoal, mas como fonte mesma dos estímulos e apelos a esta elaboração pessoal. Esta apareceria então como manifestação de uma atividade originária, no quadro da "virada ontológica" da filosofia de Pareyson:

O contexto filosófico geral no qual se move nosso pensador, com efeito - um contexto que (...) exclui decididamente a possibilidade de uma abordagem, digamos assim, frontal ou imediata à transcendência -, endereça a intenção fundamental desta mesma ontologia não tanto sobre um artífice divino das dimensões materiais ou objetivas da situação - sobre um "Figurador" inacessível por via direta -, quanto ao contrário, sobre as dimensões alusivas e simbólicas desta última. ${ }^{318}$

Neste sentido, a recusa de uma excessiva objetivação da metafísica da figuração, como já notada por Eco à época de sua elaboração, encontra acolhida e maior justificação no desenvolvimento posterior do pensamento de Pareyson. O horizonte metafísico aí vislumbrado não atua como dado a partir do qual se deduz a condição da arte ou do belo natural, mas como instância encontrada através de uma análise da experiência, da realidade como vivida e interpretada. E mesmo aí, ganha contornos mais diáfanos à medida que a dimensão ontológica passa a preponderar na reflexão do autor. No que toca ao questionamento da natureza, porém, outra circunstância deve ser recordada. Naqueles ecos futuros da

\footnotetext{
${ }^{317}$ CIGLIA, F. P. Ermeneutica e libertà, p. 178.

${ }^{318}$ CIGLIA, F. P. Ermeneutica e libertà, p. 181.
} 
metafísica da figuração apontados por Ciglia, e encontráveis em obras já não dedicadas à estética, a esfera natural não é mais especificamente tematizada no contexto da formatividade, da arte ou da beleza. ${ }^{319}$

Com estes esclarecimentos, conclui-se o exame dos elementos fundamentais da teoria da formatividade, aqui sempre lidos à luz das relações entre arte e natureza nela encontradas. De posse dos mesmos, pode-se proceder a uma tentativa de compreensão de como as duas realidades se articulam no quadro de uma "filosofia da pessoa".

\footnotetext{
319 O tema da natureza não está ausente do pensamento posterior do filósofo, e reaparece no contexto da "ontologia da liberdade". Ali, ela surge ligada à perquirição sobre a liberdade e o mal, e se mira sob uma perspectiva mais sombria e trágica, bem como no contexto de uma revalorização do discurso mítico - preocupações peculiares ao último Pareyson. Embora sejam possíveis, sem dúvida, novos aportes a partir de uma leitura conjunta destes domínios, optou-se aqui - uma vez que esta pesquisa se restringe à teoria da formatividade - em não trazer estes elementos à discussão. Estes, conquanto talvez úteis à compreensão do problema da natureza na filosofia de Pareyson como um todo, guardam importância mais limitada ao esclarecimento específico de sua estética, e ficam aqui assinalados apenas como sugestão de eventuais desdobramentos futuros desta pesquisa. Recorde-se, em apoio deste posicionamento, um documento pareysoniano esclarecedor e bastante tardio, e que tem por tema a natureza. Os apontamentos de Pareyson para uma fala a proferir num congresso sobre "Goethe e a filosofia da natureza", realizado em 1987, foram recolhidos e publicados postumamente por F. Tomatis, sob o título "La natura tra estetica e ontologia" (ver referências bibliográficas). Este texto, como anuncia o título a ele aposto pelo compilador, faz um percurso que vai das relações estéticas entre natureza e arte à ideia da natureza como transcendência, e trata, em suas últimas partes, do lugar da natureza face ao mal e a corrupção, Deus e a liberdade, o sofrimento, e temas correlatos. Contudo, na seção do texto dedicada à estética - já citada diversas vezes ao longo deste estudo - Pareyson reexpõe (e, nesse sentido, reitera) os traços fundamentais de sua concepção da relação artenatureza: a influência determinante de Goethe, a afirmação de um nisus formativus natural, o caráter orgânico do devir da obra, a dialética de liberdade e obediência que marca sua produção, etc., patenteando assim a continuidade destes elementos em seu pensamento.
} 


\section{Conclusão: natureza e filosofia da pessoa}

Ao salientar a abrangência e sistematicidade da estética pareysoniana, Blanco Sarto enfatiza que esta "deseja estudar não só todos e cada um dos momentos da produção da obra de arte, senão também as características desta e sua recepção por parte do leitor. Além disso, pretende abarcar todas as artes, precisamente porque aspira a dar uma 'definição geral da arte",. ${ }^{320}$ Nela se podem identificar, pois, diversos "momentos" distintos, nem sempre presentes em conjunto numa única teoria estética: tem-se uma definição geral da arte, empenhada em circunscrever-lhe os limites em suas mais diversas manifestações; uma descrição, de caráter "fenomenológico-existencial", da prática artística, explicitando seus momentos e sua dinâmica peculiar; uma consideração da obra de arte em sua autonomia e potencialidades próprias; e por fim, uma "estética da recepção", a qual descreve a experiência de leitura e contemplação das obras.

Com base no exposto nos capítulos precedentes, verifica-se que a relação entre arte e natureza é tematizada em todos os momentos da teoria. Assim, do ponto de vista da definição geral da arte, esta repropõe - como corolário do caráter inovador da formatividade - a ideia da arte como imitação da natureza. No que toca ao fazer artístico, tem-se uma descrição do mesmo a partir de uma aproximação aos processos de desenvolvimento orgânico. Do mesmo modo, o discurso acerca da obra entende-a primariamente como organismo, forma conclusa em si, independente e autônoma. Por fim, do ponto de vista da experiência da arte, esta se explica como um processo de interpretação que colhe a forma como beleza, e que se estende de modo categórico à esfera natural, reivindicando o potencial estético da natureza, à qual se atribui poder formante. Igualmente, verifica-se que as relações entre arte e natureza foram aí analisadas da perspectiva da produção e da contemplação, apontando para a necessária correlação entre ambas.

\footnotetext{
${ }^{320}$ BLANCO SARTO, P. Hacer arte, interpretar el arte, p. 53.
} 
Estes paralelos convidam, assim, à discussão sobre um eventual caráter "naturalista" da estética de Pareyson, tema ocasionalmente trazido à baila nas interpretações dela propostas. Trata-se aqui, evidentemente, de uma referência ao sentido propriamente filosófico do termo (como recusa de instâncias ideais, duais, transcendentais ou sobrenaturais em prol de explicações de pendor empírico ou científico, ou numa tendência a explicações a partir de dados naturais oriundos da observação ou de ciências particulares) e não do sentido estético (poético, no sentido pareysoniano) de representação adequada da natureza. ${ }^{321}$ No caso específico em tela, sugere uma explicação do fenômeno artístico em termos de operações naturais, e em continuidade e conformidade às formas e modos de atuação natural. ${ }^{322}$

Alguns poucos intérpretes da estética de Pareyson voltaram-se sobre este tema, em contexto analítico ou crítico. Morpurgo-Tagliabue, por exemplo, entende que a ênfase pareysoniana na objetividade e autonomia da forma tenta afastar o risco de seu personalismo recair em subjetivismo idealista. É nessa clave que lê a dialética entre forma formante e forma formada - que faz o desenvolvimento da obra semelhante ao de um organismo natural - afirmando seu contraste objetivo face à dimensão subjetiva e espiritual da pessoa. Admite, em seguida, o risco oposto, com base na aproximação pareysoniana entre o operar humano e o natural:

Um tal princípio evoca o princípio kantiano da arte que opera como a natureza, mas sem as precauções metodológicas da teleologia kantiana. A posição de Pareyson é, a nosso juízo, muito mais ousada, e ameaça cair no naturalismo puro e simples. Dizemos que a sua é uma posição intermediária entre o personalismo e o naturalismo e que ele busca energicamente realizar uma síntese de ambos. ${ }^{323}$

Considerações análogas se encontram em Sainati, que - conquanto aponte em Pareyson um esforço de mediação entre a iniciativa espiritual e a encarnação física da realidade artística, esforço que no seu entender seria avesso a qualquer redução naturalista - adverte no seio da teoria elementos que apontam para o

\footnotetext{
${ }^{321}$ Cf. MUNRO, T., Meanings of "Naturalism" in Philosophy and Aesthetics, pp. 133-134.

${ }^{322}$ Num sentido próximo, portanto, ao de que o próprio Pareyson se vale ao abordar a concepção estética de Goethe: "Toda a obra de Goethe se pode interpretar como um grandioso hino à eternidade e divindade da Natureza (...). De igual modo, o pensamento estético de Goethe se entronca neste naturalismo pessoal, ficando determinada sua concepção da arte por sua visão da natureza" (PAREYSON, L., Conversaciones de estética, p. 139).
} 
naturalismo como um seu "risco imanente". ${ }^{324}$ Analisando a teoria a partir de pressupostos transcendentalistas, assinala em Pareyson uma oscilação, no que toca às relações entre intenção formativa e matéria adotada, ou espiritualidade e fisicidade da obra, para citar dois exemplos de dualidades resolvidas em unidade pela teoria. Esta oscilação seria entre uma consideração sintética (relação vista como um processo de identificação dinâmica que guardaria alguma descontinuidade entre os dois termos) e uma consideração analítica (relação vista como simples identidade). ${ }^{325} \mathrm{~A}$ ênfase pareysoniana no momento analítico manifestada, por exemplo, na afirmação de que a obra só significa a si mesma ou na aproximação do processo tentativo da arte ao desenvolvimento orgânico seriam motivos tendentes a este naturalismo. E principalmente, acusa tal tendência na tese de um esforço formativo da própria natureza, simultaneamente modelo da figuratividade humana e condição do belo natural, denunciando a inconveniência teórica da inclusão desta discussão em meio ao problema da arte, no que considera um desvio no sentido de "uma metafísica romântica da natureza, no mínimo alheia à impostação pareysoniana do problema da arte". ${ }^{326}$

Em contraponto a esta visão, no entanto, deve-se insistir em que, de um ponto de vista sistemático, o tratamento desta questão pela estética da formatividade é essencial à consistência da mesma. Ao afirmar a valência estética de toda a esfera operativa humana, a pergunta acerca da eventual esteticidade da natureza se põe inexoravelmente. Entende-se aqui, portanto, que a inclusão desta discussão se mostra não somente lícita, mas necessária a partir da concepção de experiência estética em termos de formatividade, ainda que se venha a considerála problemática ou insuficiente do modo como efetivamente se desenvolve no pensamento de Pareyson. Deve-se recordar, também, que a aproximação da arte ao desenvolvimento de um organismo responde à abertura do operar humano e da receptividade que em parte o constitui. E que aquela dissociação de aspectos entre esforço pessoal a teleologia interna, longe de postular o gênio como natureza que fala através do artista, mantém a abertura ontológica enquanto reitera a

\footnotetext{
${ }^{323}$ MORPURGO-TAGLIABUE, G., L'esthétique contemporaine: une enquête, p. 545.

${ }^{324}$ Cf. SAINATI, V., Discorso critico sulla teoria della formatività, pp. 373-374.

${ }^{325}$ Cf. SAINATI, V., Discorso critico sulla teoria della formatività, pp. 353-355.

${ }^{326}$ SAINATI, V., Discorso critico sulla teoria della formatività, p. 374.
} 
personalidade própria do operar, resguardando sua insuficiência ao mesmo tempo em que afirmando um decidido princípio de autoria pessoal.

Considerações do mesmo teor podem ser feitas quanto à formatividade natural. Se o homem conhece aquilo que ele faz, Pareyson julga que "por analogia com a formatividade humana, se poderá também entender a formatividade natural, e com a teleologia subjetiva, a objetiva". ${ }^{327}$ Nesse sentido, é oportuno recordar, seguindo Mura, a dupla radicação dos discursos pareysonianos sobre a arte e a natureza. É a partir de uma filosofia da pessoa que se constitui e explica a arte em sua generalidade e em sua especificação, enquanto é a partir de uma gnoseologia da interpretação que se resolve a questão acerca do belo natural. ${ }^{328}$ Conforme afirma Pareyson, "a estrutura mesma da interpretação é indício suficiente para concluir que as coisas são, elas mesmas, formas, e por sua vez, resultados de figuração". ${ }^{329}$ A gnoseologia da interpretação é, no entanto, igualmente inseparável de uma filosofia da pessoa.

Se o conhecimento é interpretação de formas, e se a contemplação é culminação de tal processo, o belo natural supõe que as coisas da natureza sejam interpretáveis, logo formas, e se isto se verifica, é um pressuposto da interpretação da natureza que esta possua por si um poder formante. Se se chega à formatividade humana pela análise do homem em seu operar, é a partir de seu igualmente ativo interpretar que se pode afirmar - categórica, mas indiretamente uma "formatividade natural". A interpretação se reconhece como prolongamento da formatividade natural no ato em que - como prolongamento - a interpreta.

Assim, o belo natural se pode apreciar como resultado de formação, embora, como salienta Pareyson, o esforço de contemplar-lhe a beleza deva cercar-se do desvelo e interesse que, análoga e exemplarmente, se dedica ao conhecimento das pessoas, se aquelas, como estas, contêm "em seu próprio caráter definido, uma singular abertura e mobilidade". ${ }^{330}$ Se a abrangente concepção estética de Pareyson implica uma "formatividade universal", suas modalidades não se afirmam de modo unitário, embora se afirmem ambas pela mediação da pessoa. A formatividade natural é aí indiretamente entendida em comparação à - e à luz da -

\footnotetext{
${ }^{327}$ FERRARIS, M., Un'estetica senza opere, p. 95.

${ }^{328}$ Cf. MURA A., La concezione estetica in Luigi Pareyson, p. 19.

${ }^{329}$ PAREYSON, L., Problemi dell'estetica I. Teoria , p. 118 (grifo meu).

${ }^{330}$ PAREYSON, L., Estética: teoria da formatividade, p. 200.
} 
formatividade pessoal, esta sim examinada em sua dinâmica peculiar e em suas determinações próprias, tais como se dá no formar e no interpretar.

Os liames entre arte e natureza propostos por Pareyson apresentam, com efeito, alguns contornos problemáticos. Uma excessiva continuidade entre as duas dimensões é salientada por Morpurgo-Tagliabue, a partir de sua crítica do que considera uma insuficiente distinção entre as esferas artística e estética na teoria da formatividade, e julga que a aproximação proposta por Pareyson entre arte e natureza contribui para a dissolução das fronteiras entre artístico e estético. Tal postura mascararia a especificidade própria da arte, que seria considerada apenas sob o aspecto comum que guarda com as demais produções humanas. Embora a ênfase na produção autônoma de "coisas entre coisas" seja licitamente aplicável à arte, o inegável foco pareysoniano na continuidade sem saltos entre os domínios pareceria deixar algo por dizer em relação ao tipo de experiência absolutamente singular que só a arte promove:

É fora de dúvidas que a perfeição, a completude, a finalidade, são prerrogativas das coisas belas: mas no sentido menos autônomo, no sentido do belo-bem, do bem feito, não naquele sentido extremo, raro e difícil, segundo o qual intentamos eleger, turbados, as coisas belas. ${ }^{331}$

$\mathrm{Na}$ mesma seara, citem-se as ressalvas formuladas por Vecchi quanto à aproximação entre os "produtos" da arte e da natureza, a partir do vínculo estabelecido entre produção e fruição:

Se supomos na natureza um poder formativo e formante porque nos encontramos diante de formas, devemos constatar que a finalidade com a qual foram produzidas é muito distante daquela de ser colhidas enquanto formas, e logo, como beleza. Talvez a forma seja uma astúcia da natureza, um meio do qual se serve para o conseguimento de seus fins. (...) Daí deriva que ainda que nos ponhamos diante das coisas da natureza, com uma intenção programática de colher-lhes a beleza, nosso processo de interpretação não poderá fazê-lo senão através de momentos de pausa. O prosseguimento inevitável insta a algo outro que a beleza. ${ }^{332}$

$\mathrm{O}$ aceno à transitoriedade da natureza, que enfim suprime as formas mesmas que engendra num fluxo constante, e se opõe à ideal fixidez da arte, era já assinalado, aliás, pelo próprio Pareyson (e por seu mestre nesta matéria, Goethe), e aponta, no entender de Ferraris, para uma necessária limitação do alcance de sua

\footnotetext{
${ }^{331}$ MORPURGO-TAGLIABUE, G. Problemi attuali dell'estetica, p. 332.

${ }^{332}$ VECCHI, G., L'estetica della formatività di Luigi Pareyson, p. 363.
} 
aproximação entre arte e natureza. ${ }^{333}$ Se, como aponta Vecchi, o formar da natureza não tem (ou, dizendo-o melhor: ao menos não se pode afirmar que tenha) finalidades puramente estéticas, conquanto isto em nada obste a usual experiência estética das formas naturais, a legitimidade de sua aproximação à arte em sentido estrito se mostra problemática. Se a visão de formas na arte supõe sua condição de puras formas (pois uma consideração puramente formal de produtos oriundos de outras atividades resulta em esteticismo), põe-se em questão o alcance do paralelismo entre obras de arte e formas naturais, ao menos sob o aspecto da interpretação das mesmas. As belas coisas naturais se permitiriam ser consideradas sob esta luz, mas não mais que isso. Nesse sentido, Vecchi sustenta que, a rigor, a experiência do belo natural estaria mais próxima da circunstancial "pausa contemplativa" admitida para a experiência do belo nos demais empenhos formativos do que na arte em sentido estrito, e que o paralelismo proposto por Pareyson seria uma pressuposição antes que uma coincidência fundamentada. ${ }^{334}$

A questão do teor naturalista da estética da formatividade é, enfim, revisitada por Ferraris, que ressalta o princípio de analogia que perpassa esta e outras dimensões da mesma: a afirmação pareysoniana segundo a qual " a obra se faz de si e no entanto a faz o artista se entende na sua posição mais exata quando se tem presente que o nexo entre natureza, arte e homem (...) especifica-se no mundo só através da regra da analogia", de modo que "natureza, obra e homem são análogos sob certos aspectos, mas de todo modo não são o mesmo". 335

O mesmo comentador contempla o presumido naturalismo de Pareyson no quadro da recusa de uma leitura historicista da arte: em lugar de mirar o devir histórico das obras e de suas leituras, Pareyson, tomando a forma histórica por extrínseca, busca mostrar como, "com base numa imanente teoria da formatividade calcada numa metafísica da forma, o formar-se do homem enquanto detentor de história seja o análogo (ou ainda a figura) do formar-se da obra de arte e da natureza, reduzidos sob um único princípio". 336 Inobstante, o citado princípio analógico impediria uma excessiva aproximação ou confusão entre os âmbitos de arte e natureza, e não os reduziria a uma simples continuidade:

\footnotetext{
${ }^{333}$ Cf. FERRARIS, M. Un'estetica senza opere, pp. 102-103.

${ }^{334}$ Cf. VECCHI, G., L'estetica della formatività di Luigi Pareyson, p. 363.

${ }^{335}$ FERRARIS, M. Un'estetica senza opere, p. 103 (grifos do autor).

${ }^{336}$ FERRARIS, M. Un'estetica senza opere, p. 100.
} 
Ou aproxima-se à arte através da analogia com a natureza, ou se o faz por meio da história. E como Croce não levará nunca a analogia histórica até o ponto de subscrever a sanção da arte como coisa do passado, assim Pareyson nunca pensou numa redução da arte à natureza (...). Para Pareyson, comentador de Goethe, a arte obtém êxito somente se procede como a natureza, donde se poderá observar como o acento cai antes sobre o papel da analogia (e reenvie assim a uma metafísica não da natureza, mas da forma); mais que tudo, a obra é um análogo da natureza somente se é uma obra exitosa. ${ }^{337}$

A vida é produção de formas, e tem-se a arte quando este formar passa a ser buscado por si mesmo, quando se persegue uma forma que não queira senão valer como forma. Nestas obras humanas, submetidas quaisquer alheias finalidades ao puro caráter de êxito formal, as coisas produzidas parecem, em sua gratuidade e contingência e em sua patente realidade material, estar simplesmente dadas: "como as coisas da natureza, assim também as obras de arte possuem o traço de serem puras existências, que se dão inteiramente em sua presença física, simbolizando apenas a si mesmas". ${ }^{338}$ Deste compartilhamento de propriedades comuns, não decorre identidade: a obra de arte não é um organismo natural, mas uma personalidade feita objeto físico, é um profundo significado humano dado como pura presença, em sua gratuidade e autonomia. ${ }^{339}$ Para fazer-se presença física, a obra deve ser corpo, physis, matéria formada, no que exige uma base natural, uma matéria já formativamente orientada como condição do puro formar. Mas só se mostra como um "organismo" de pleno direito quando alcança a condição de pura forma, quando sua produção é lograda. Assim, “é só a obra exitosa a fazer-se natureza, de modo que a naturalidade é aqui, antes que tudo, um critério (inteiramente humano e espiritual) de excelência". 340

Esta referência ao elemento humano e espiritual é oportuna, enquanto acena ao fato de que é a partir de uma filosofia da pessoa, que toda a preocupação estética de Pareyson, aí incluído o belo natural e funcional, se erige. ${ }^{341}$ É lícito recordar aqui o que Pareyson considera um dos traços essenciais do pensamento filosófico: a afirmação da filosofia como obra do homem, feita pelo homem e para

\footnotetext{
${ }^{337}$ FERRARIS, M. Un'estetica senza opere, p. 101.

${ }^{338}$ PAREYSON, L., Estética: teoria da formatividade, p. 117.

${ }^{339}$ Cf. PAREYSON, L., Esistenza e persona, p. 225.

${ }^{340}$ FERRARIS, M. Un'estetica senza opere, p. 101.

${ }^{341}$ Cf. FINAMORE, R., Arte e formatività, p. 79.
} 
o homem, nela identificado como perspectiva, como interlocutor e como objeto. É esta afirmação também uma genuína conquista da autoconsciência filosófica, se se observa que o curso do pensamento vira já tantas filosofias que não cuidaram de se fazer cônscias deste ponto de vista particular - a pessoa empenhada no filosofar. Igualmente a filosofia como comunicação supõe no homem o seu interlocutor e destinatário. No mais,

Que o objeto da filosofia seja somente o homem é coisa que pareceu menos óbvia, se quase todas as filosofias do ser e do absoluto creram poder falar destes objetos diretamente e objetivamente, como se se tratasse de objetos acessíveis ao puro pensamento ou formuláveis exclusivamente pelo pensamento filosófico, antes que relações constitutivas da natureza humana e relações decisivas para a vida mesma do homem. ${ }^{342}$

Um discurso sobre a natureza, mesmo em seus aspectos formativos, deve ser referido a esta centralidade da pessoa. Viu-se anteriormente que, mesmo no quadro de uma "metafísica da figuração" este horizonte teorético não se confunde com aquele esperável de uma metafísica de tipo clássico, no qual o estatuto da natureza pudesse ser fundamentado como se a partir de si mesmo. Se se remonta ao âmbito mais geral da relação da pessoa com o ser e a verdade, vê-se, na preocupação ontológica pareysoniana, antes uma "metafísica antropológica", ou seja, "uma metafísica do ser mediata e indireta, que passa sempre através da filosofia da pessoa. Isto é, a fundamentação imediata e penúltima da estética de Pareyson se encontra na pessoa, enquanto que o ser será seu fundamento último, mas indireto". ${ }^{343}$ O discurso sobre a transcendência aparece aí como necessariamente condicionado, ainda que revelador da verdade e do ser.

O caráter analógico da relação da arte com a natureza é sob este aspecto igualmente significativo. Pareyson, que não propõe uma metafísica da natureza ou uma Naturphilosophie (o que seria problemático a partir de seus pressupostos), aborda a natureza a partir da pessoa, em sua relação com a pessoa, e encontra a formatividade natural a partir da referência à formatividade humana, existencialmente fundada. Este fundamento existencial da formatividade é trazido ao primeiro plano por Carchia, ao salientar que o fazer exitoso da obra depende integralmente do artista e de seu esforço, com o caráter arriscado e aventuroso de que tal processo se reveste. Assim, nota que, "embora compartilhando com

\footnotetext{
${ }^{342}$ PAREYSON, L., Esistenza e persona, p. 227.
} 
Goethe a visão da forma como crescimento e como organismo, a teoria da formatividade não a vincula a essências e arquétipos supratemporais, mas antes a insere na imprevisível caducidade do mundo". ${ }^{444}$ A experiência estética pode aí ser vista como aquela "epifania do humano" de que trata Caneva, se se recorda a afirmação pareysoniana da arte como "a mais complexa e enigmática das atividades humanas". 345

Assim, se é verdade que sua estética "continua" a de Goethe, como o próprio Pareyson sustenta, talvez não se possa dela afirmar o que ele afirma categoricamente da do autor alemão, a saber: que sua concepção de arte depende de sua concepção da natureza, de modo que "quem queira, em qualquer momento da evolução espiritual de Goethe, dar-se conta exatamente de sua estética, deverá remeter-se ao seu modo de ver e sentir a natureza". ${ }^{346}$ A analogia entre arte e natureza parece ser, em Pareyson, reencontrada a partir de uma consideração da peculiaridade do fazer humano face à natureza tal como esta se mostra à interpretação, antes que fundada numa afirmação radical de unidade ou comunhão entre os dois âmbitos ou de uma derivação da arte a partir da natureza.

Como recorda Blanco Sarto, se Pareyson foi tachado de naturalista por esta remissão a um princípio da natureza para compreensão da arte, deve-se recordar que ele igualmente afirmou o princípio da pessoa e de sua existência, limitando uma aproximação excessiva entre os dois domínios. ${ }^{347}$ Diante disto, e de posse das considerações tecidas até aqui, permite-se afirmar que, se é possível pensar a estética pareysoniana à luz das dimensões "naturalista" e "personalista", como

\footnotetext{
${ }^{343}$ BLANCO SARTO, P. Hacer arte, interpretar el arte, p. 265 (grifos do autor).

${ }^{344}$ CARCHIA, G., Esperienza e metafisica dell'arte, p. 78.

${ }^{345}$ PAREYSON, L., Os problemas da estética, p. 41. Ver também CANEVA, C., Bellezza e persona.

${ }^{346}$ PAREYSON, L., Estetica dell'idealismo tedesco III. Goethe e Schelling, p. 11. Quanto à afirmação pareysoniana de que sua estética continua a de Goethe, ver PAREYSON, L., Estetica dell'idealismo tedesco III. Goethe e Schelling, p. 5. Continuar não implica, contudo, simplesmente assimilar. Pareyson recorda que, disposta a se manter fiel a Goethe, sua reflexão exigiu "um desenvolvimento extremamente sutil, e custou-me uma busca de contínuos reequilíbrios para manter as coisas balanceadas e não deixar uma parte preponderar" (PAREYSON, L., La natura tra estetica e ontologia, p. 12. O trecho citado se segue à discussão da necessidade de conciliação das propostas de Goethe e Valéry quanto ao processo artístico).

${ }^{347}$ Cf. BLANCO SARTO, P., Hacer arte, interpretar el arte, p. 60.
} 
propõe Morpurgo-Tagliabue, deve-se reconhecer a subordinação da primeira à segunda. E, por conseguinte, também a descontinuidade que se estabelece entre formatividade natural e humana, a precedência desta face àquela, e o sentido em que o formar natural se inscreve nesta filosofia da pessoa.

Por tudo isto, pode-se concluir que o estatuto estético da natureza na teoria da formatividade se coaduna com o "personalismo ontológico" ou a "ontologia do inexaurível" pareysonianos, ainda que as breves ressalvas levantadas convidem a ulteriores análises, aqui apenas sugeridas. A natureza é coerentemente compreendida, por um lado, nos termos da fruição estética que suscita e, por outro, como paradigma à produção humana, especialmente àquela produção característica que, por sua autonomia, chamamos arte. Isto se dá sem que se ultrapassem as reivindicações de uma filosofia da pessoa, cuja experiência e abertura é base e via de mediação para a compreensão da natureza. O formar natural é vislumbrado a partir da própria formatividade pessoal, como interpretação, e reconhecido como correspondente, adequado e semelhante a esta. Por isso, mais que uma transparente visão da natureza em seus recônditos desígnios, esta perspectiva filosófica, calcada no respeito à realidade inexaurível, abre apenas, como diz Pareyson, uma "suficiente fenda metafísica" através da qual se vislumbre algo de seu íntimo. ${ }^{348}$

\footnotetext{
${ }^{348}$ A expressão em questão se encontra em PAREYSON, L., Esistenza e persona, p. 221.
} 


\title{
Referências bibliográficas
}

\author{
Bibliografia primária
}

PAREYSON, Luigi. Conversaciones de estética. (trad. Zósimo González) Madrid, Visor, 1988.

Esistenza e persona. Genova, II melangolo, 1985.

. Estetica dell'idealismo tedesco I: Kant e Schiller. Milano, Mursia, 2005.

. Estetica dell'idealismo tedesco III: Goethe e Schelling. Milano, Mursia, 2003.

. Estética: teoria da formatividade. (trad. Ephraim Ferreira Alves) Petrópolis, Vozes, 1993.

. Estética: teoria della formatività. Mllano, Bompiani, 1996.

. "La natura tra estetica e ontologia" (ed. Francesco Tomatis) in Annuario Filosofico, oo 9, 1993, pp. 9-23.

. Os problemas da estética. (trad. Maria Helena Nery Garcez) São Paulo, Martins Fontes, 2001.

. Problemi dell'estetica I: Teoria. Milano, Mursia, 2009.

. Problemi dell'estetica II: Storia. Milano, Mursia, 2000. 
Verdade e interpretação. (trad. Maria Helena Nery Garcez e Sandra Neves Abdo), São Paulo, Martins Fontes, 2005.

Bibliografia secundária

ARISTÓTELES, Física. (trad Guillermo R. de Echandía). Madrid, Gredos, 1995.

. Partes dos animais. (trad Maria de Fátima Sousa e Silva). Lisboa, Imprensa Nacional-Casa da Moeda, 2010.

BLANCO SARTO, Pablo. Hacer arte, interpretar el arte: Estética y hermenéutica en Luigi Pareyson, Pamplona, Eunsa, 1998.

BROWN, Merle E. “On Luigi Pareyson's L'estetica di Kant: a review article" in Journal of Aesthetics and Art Criticism, 29 (3), 1971, pp.403410.

CANEVA, Claudia. Bellezza e persona: l'esperienza estetica come epifania dell'umano in Luigi Pareyson. Roma, Armando Editore, 2008.

CARCHIA, Gianni. “Esperienza e metafisica dell'arte: l'estetica di Luigi Pareyson" in Rivista di estetica, 1993, no 40-41, pp. 76-86.

CARR, Herbert Wildon. The philosophy of Benedetto Croce: the problem of art and history. London, Macmillan and Co., 1917.

CIGLIA, Francesco Paolo. Ermeneutica e libertà: I'itinerario filosofico di Luigi Pareyson, Roma, Bulzoni, 1995.

COPPOLINO, Santo. Estetica ed ermeneutica di Luigi Pareyson. Roma, Cadmo Editore, 1976. 
CROCE, Benedetto. Breviário de estética; Aesthetica in nuce. (trad. Rodolfo llari Jr.). São Paulo, Ática, 1997.

. Estetica come scienza dell'espressione e linguistica generale. Bari, Laterza, 1912.

D’ANGELO, Paolo. Estetica. Roma-Bari, Laterza, 2011.

. "Il ruolo di Luigi Pareyson nell'estetica italiana del Novecento" in Annuario Filosofico, N. 27 (2011) Milano, Ugo Mursia, p. 59-74.

"L'opera d'arte come ricerca e come riuscita: la considerazione dinamica del processo artistico in tre estetiche postcrociane" in Rivista di estetica, 1983, № 23, pp. 69-94.

DUARTE, Pedro. Estio do tempo: romantismo e estética moderna. Rio de Janeiro, Zahar, 2011.

ECO, Umberto. A definição da arte. (trad. José Mendes Ferreira). São Paulo, Martins Fontes, 1986.

FERRARIS, Maurizio. "Un'estetica senza opere” in Rivista di estetica, 1993, № 40-41, pp. 87-109.

FINAMORE, Rosanna. Arte e formatività: l'estetica di L. Pareyson. Roma, Città Nuova, 1999.

. "Il discorso sull'essere di Luigi Pareyson", in Proceedings of the Metaphysics for the Third Millennium Conference, vol. I. Escuela Idente- Universidad Técnica, Particular de Loja, Roma-Loja 2001. 
GIMÉNEZ-SALINAS, Constanza. "Las principales cuestiones hermenéuticas de Luigi Pareyson" in Pensamiento y Cultura, vol. 16-1 junio de 2013, pp. 113-137.

GIVONE, Sergio. Historia de la estética. (trad. Mar García Lozano). Madrid, Tecnos, 1999.

KALAR, Brent. The demands of taste in Kant's aesthetics. London-New York, Continuum, 2006.

KANT, Immanuel. Crítica da faculdade do juízo. (trad Valério Rohden e António Marques). Rio de Janeiro, Forense Universitária, 2012.

LEDDY, Tom. "The nature of everyday aesthetics" in The aesthetics of everyday life (ed. Andrew Light e Jonathan M. Smith), New York, Columbia University Press, 2005.

MORPURGO-TAGLIABUE, Guido. L'esthétique contemporaine: une enquête. Milano, Marzorati, 1960. "Problemi attuali dell'estetica" in // Pensiero. Volume VI, n. 3, 1961.

MUNRO, Thomas. 'Meanings of 'Naturalism' in Philosophy and Aesthetics" in The Journal of Aesthetics and Art Criticism, Vol. 19, No. 2 (Winter, 1960), pp. 133-137.

MURA, Antonio. La concezione estetica in Luigi Pareyson. Roma, Pontificia Universitas Gregoriana, 1967.

NUNES, Benedito. Introdução à filosofia da arte. São Paulo, Ática, 2003. 
OLIVEIRA, João Vicente Ganzarolli de. Estética, vivência humana: temas e controvérsias na filosofia. Rio de Janeiro, Letra Capital/FAPERJ, 2008.

OLIVEIRA, Renata Gabriel de. A obra de arte como um fato hermenêutico-ontológico: a visão de Luigi Pareyson. Dissertação de mestrado. Belo Horizonte, Universidade Federal de Minas Gerais, 2008.

PLAZAOLA, Juan. Introducción a la estética: historia, teoría, textos. Madrid, BAC, 1973.

PINERI, Riccardo. "Une pensée de l'ouverture. Luigi Pareyson" in Les études philosophiques, 4, 1994, pp. 543-553.

RICCI SINDONI, Paola. "Sul concetto di 'bellezza aderente': Pareyson legge Kant" in La tradizione kantiana in Italia, II, Edizioni G.M.B., Messina, 1986, pp. 581-598.

RUSSO, Francesco. "Contemplazione e interpretazione: l'estetica kantiana nell'analisi di Luigi Pareyson" in Acta philosophica, 1995, vol. 4, fasc. 1, pp. 105-110.

RUSSO, Raffaele. "La natura come forma elementare dello spirito: Benedetto Croce e il diritto al paesaggio" Paper discusso a Dobbiaco il 30 agosto 2012, nel corso del seminario di studi Panorami del sapere: Croce, l'ambiente, il paesaggio.

SAINATI, Vittorio. "Discorso critico sulla teoria della formatività" in Giornale critico della filosofia italiana, 3 (1961), pp. 341-375.

STACE, W. T. A critical history of greek philosophy. Auckland, The Floating Press, 2010. 
TATARKIEWICZ, W. Historia de seis ideas: arte, belleza, forma, creatividad, mímesis, experiencia estética. (trad. Francisco Rodríguez Martín), Madrid, Tecnos, 1997.

TOMATIS, Francesco. Pareyson: vita, filosofia, bibliografia. Brescia, Morcelliana, 2003.

VALVERDE, M. "Les limites du jeu poétique" in Sociétés, 2002/2, n. 76, 2002, pp. 49-58.

VECCHI, Giovanni. “L'estetica della formatività di Luigi Pareyson” in Rivista di filosofia neoscolastica, 4-6 (1956), pp. 352-363. 